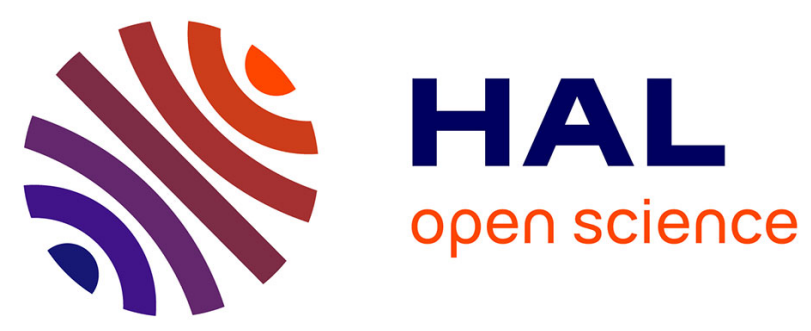

\title{
New Siluro-Devonian anomalocystitids (Echinodermata, Stylophora) from Bolivia and Canada, and a reevaluation of skeletal homologies in mitrates
}

Bertrand Lefebvre, William I. Ausich

\section{- To cite this version: \\ Bertrand Lefebvre, William I. Ausich. New Siluro-Devonian anomalocystitids (Echinodermata, Sty- lophora) from Bolivia and Canada, and a reevaluation of skeletal homologies in mitrates. Paleonto- logical Journal / Paleontologicheskii Zhurnal, 2021, 10.1134/S0031030121090070 . hal-03004811}

\section{HAL Id: hal-03004811 https://hal.science/hal-03004811}

Submitted on 13 Nov 2020

HAL is a multi-disciplinary open access archive for the deposit and dissemination of scientific research documents, whether they are published or not. The documents may come from teaching and research institutions in France or abroad, or from public or private research centers.
L'archive ouverte pluridisciplinaire HAL, est destinée au dépôt et à la diffusion de documents scientifiques de niveau recherche, publiés ou non, émanant des établissements d'enseignement et de recherche français ou étrangers, des laboratoires publics ou privés. 


\title{
New Siluro-Devonian anomalocystitids (Echinodermata,
}

\section{Stylophora) from Bolivia and Canada, and a reevaluation of}

\section{skeletal homologies in mitrates}

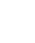

\author{
B. Lefebvre ${ }^{a, *} \&$ W.I. Ausich ${ }^{b, * *}$
}

${ }^{a}$ UMR CNRS 5276 LGLTPE, bâtiment Géode, campus de la Doua, Université Lyon 1, 2 rue Raphaël Dubois, F(1) 69622 Villeurbanne cedex, France

${ }^{b}$ School of Earth Sciences, 125 South Oval Mall, The Ohio State University, Columbus, OH 43210 USA

*e-mail: bertrand.lefebvre@univ-lyon1.fr

**e-mail: ausich.1@osu.edu

Abstract- Two new mitrate stylophorans are described from the upper part of the Santa Rosa Formation (Lochkovian) in the Central Subandean Zone of Bolivia and from the Jupiter Formation (Cybèle Member, late Llandovery) of Anticosti Island (Canada). Both stylophorans are identified as allanicytidiine anomalocystitids. The new Bolivian mitrate, Perikefalea racheboeufi gen. and sp. nov. is characterized by a strongly reduced number of plates (five) on its upper thecal surface and a strong spike on its posterior median marginal. The morphology of $P$. racheboeufi suggests relatively strong affinities with Occultocystis, from the Lower Devonian Talacasto Formation of Argentina. Although incompletely preserved, the Anticosti mitrate, Perikefalea? cybeleae sp. nov., represents the first stylophoran described in the Silurian of North America and the first report of post-Ordovician Allanicytidiinae outside of (peri) Gondwanan regions. Skeletal homologies in mitrates (marginals, infracentrals, 5 posterior spines, adorals, supracentrals) are reevaluated, so as to describe the plate pattern of 
Perikefalea. This revision was prompted by new fossil evidence from the Furongian-

27 Tremadocian interval suggesting that (1) mitrates derive from 'Phyllocystis' jingxiensis-like cornutes with wide marginals, a posteriorly open marginal frame (loss of $\mathrm{M}_{5}$ and $\mathrm{M}_{5}$ ), a zygal plate in central position, and confluent, sutured $\mathrm{M}_{3}$ and $\mathrm{G}$; (2) anomalocystitids derive from Mitrocystites-like mitrocystitidans by modification of two marginals (digital and glossal) into posterior spines. Two distinct terminologies are tentatively proposed for supracentrals in

32

Keywords: Anticosti, Bolivia, Canada, Devonian, Echinodermata, Malvinokaffric Realm, Silurian, Stylophora

Allanicytidiinae and Anomalocystitinae, because the highly standardized plate patterns of their Siluro-Devonian representatives were possibly acquired independently in the two clades.

\section{Silurian, Stylophora}

\section{INTRODUCTION}

Stylophorans are an extinct clade of single-armed, vagile, benthic echinoderms, which flourished on soft substrates from the Wuliuan (Miaolingian, middle Cambrian) to the Bashkirian (Lower Pennsylvanian, Carboniferous) (Ubaghs, 1967a; Kolata et al., 1991; Zamora et al., 2013a; Lefebvre et al., 2019). In the late Guzhangian-late Tremadocian interval immediately preceding the major diversification of crinoids, stylophorans were a major component of worldwide echinoderm communities (Sumrall et al., 1997; Guensburg and Sprinkle, 2000; Lefebvre and Fatka, 2003; Lefebvre et al., 2013). All main stylophoran clades, including anomalocystitid mitrates, appeared and diversified during this late Cambrian-Early Ordovician interval (Lefebvre, 2007a; Lefebvre et al., 2013; Zamora et al., 2013b). In Middle Ordovician times, the paleobiogeographic distribution of stylophorans was 0 limited to high-latitude (peri-) Gondwanan areas and relatively deep settings of Avalonia 
51 (Jefferies, 1987; Lefebvre and Fatka, 2003; Lefebvre, 2007a; Botting et al., 2013). However, 52 during the Late Ordovician, they spread to Baltica and Laurentia (Mohawkian invasion), 53 where some clades (anomalocystitids, peltocystids) eventually diversified into shallower and warmer environmental conditions (Caster, 1952; Kolata and Guensburg; 1979; Kolata and Jollie, 1982; Parsley, 1982, 1991; Lefebvre, 2007a, 2007b; Lefebvre et al., 2013). Conversely, stylophorans almost disappeared from most high-latitude (peri-) Gondwanan regions during the late Katian Boda Event, with the onset of more temperate environmental conditions and the invasion of echinoderm faunas from lower latitudes (Lefebvre, 2007a, 2007b; Lefebvre et al., 2013).

Stylophorans were severely affected by the Hirnantian mass extinction, with only four clades reported from younger deposits (Lefebvre, 2007a). Although they are sometimes locally abundant (e.g. Placocystites forbesianus, in the Dudley Limestone of Britain; Rhenocystis latipedunculata, in the Hunsrück Slate of Germany; Jefferies and Lewis, 1978; Ruta and Bartels, 1998), post-Ordovician stylophorans are generally extremely rare, and their fossil record particularly sparce. For example, peltocystidans, which are one of the most abundant and widespread clades of Ordovician stylophorans, are only known from three younger occurrences: 'Mitrocystites' styloideus (Emsian, Germany; Dehm, 1934; Lefebvre, 2007a), yet undescribed Middle Devonian forms (Eifelian-Givetian, Germany; Haude, 1983) and Jaekelocarpus oklahomaensis (Bashkirian, USA; Kolata et al., 1991). Similarly, the paleobiogeographic distribution of Siluro-Devonian mitrocystitidans (Anomalocystitidae and Paranacystidae) is poorly known and suffers from a strong sampling bias. For example, paranacystids were long considered as typical members of the Early-Middle Devonian highlatitude Malvinokaffric faunas (e.g. Derstler, 1979; Haude, 1995; Ruta, 1997a; Penn-Clarke, 2019; but see Boucot and Rachebœuf, 1993). This interpretation is based on a very small 
number of occurrences from Argentina (Yachalicystis triangularis; Haude, 1995), Brazil

(Paranacystis petrii; Caster, 1954a; Caster and Eaton, 1956), and South Africa (P. simoneae;

Ruta, 1997a; Reid et al., 2015). However, the reinterpretation of the Middle Devonian genus

Dalejocystis (Czech Republic, Germany; Prokop, 1963; Haude, 1983) as a paranacystid, as

80

81

82

83

84

85

86

87

88

89

90

91

92

93

94

95

96

97

98

99

100

well as the discovery of several new occurrences in the Wenlock of Sweden (Reich et al., 2008), the Ludlow of Australia (Ruta and Jell, 1999b), the Lochkovian of Australia and Bolivia (Ruta and Jell, 1999b; Lefebvre and Rachebœuf, 2007) and the Givetian of France (Lefebvre, 1999, 2000a) suggest a more complex and widespread distribution of paranacystids.

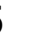

In the two main clades of anomalocystitids (Allanicytidiinae and Anomalocystitinae), the evolutionary transition from Late Ordovician to younger taxa, as well as their SiluroDevonian paleobiogeographic distribution are similarly poorly understood. Post-Ordovician anomalocystitines were traditionally considered as a 'boreal' group, restricted to low-latitude regions of the 'Old World' and 'North Eastern Americas' faunal realms sensu Boucot (1988) (see e.g. Gill and Caster, 1960; Derstler, 1979; Parsley, 1991; Ruta, 1997b; Ruta and Bartels, 1998). This interpretation relied on the very low number of Siluro-Devonian anomalocystitine taxa described between the late 1850s and the late 1990s: Anomalocystites cornutus Hall, 1859 (Lower Devonian, North America; Parsley, 1991), Placocystites forbesianus de Koninck, 1869 (Wenlock, Britain; Jefferies and Lewis, 1978), Rhenocystis latipedunculata Dehm, 1932 (Emsian, Germany; Ruta and Bartels, 1998), and Victoriacystis wilkinsi Gill and Caster, 1960 (Ludlow, Australia; Ruta, 1997b; Ruta and Jell, 1999d). However, the reinterpretation of Mongolocarpos minzhini (Ludlow, Mongolia; Rozhnov, 1990) as a probable anomalocystitine (Ruta, 1999a), as well as new discoveries in regions (Bolivia, South Africa) belonging to the Devonian Malvinokaffric faunal realm (see Ruta and Theron, 
101

102

103

104

105

106

107

108

109

110

111

112

113

114

115

116

117

118

119

120

121

122

123

124

1997; Lefebvre and Rachebœuf, 2007) suggest a more cosmopolitan distribution for SiluroDevonian Anomalocystitinae.

The second clade of post-Ordovician anomalocystitids, Allanicytidiinae, has been long considered as an 'austral' group of stylophorans, restricted to (peri-) Gondwanan regions belonging either to the eastern part of the Old World faunal realm (Australia, New Zealand) or to the higher latitude Malvinokaffric Realm (Argentina, Brazil, South Africa) (see Caster, 1954b, 1983; Ubaghs, 1967a; Philip, 1981; Parsley, 1991; Haude, 1995; Ruta, 1997b; Ruta and Theron, 1997; Ruta and Jell, 1999e; Lefebvre and Rachebœuf, 2007; Jell, 2013; PennClarke, 2019; Scheffler et al., 2019; but see Boucot and Rachebœuf, 1993). In this context, the two mitrates described here from the late Llandovery of Anticosti Island (Canada) and the Lochkovian of Bolivia are particularly important. The Canadian occurrence represents both the first stylophoran described in Silurian deposits from North America and also the first report of post-Ordovician Allanicytidiinae outside of (peri) Gondwanan regions. The Anticosti mitrate is here tentatively assigned to a new genus of allanicytidiines, described from better-preserved and more complete material from Bolivia. The morphology of the Bolivian stylophoran suggests stronger affinities with Occultocystis (Lower Devonian; Argentina) than with the widespread coeval genus Placocystella (late Llandovery-early Givetian; Australia, Brazil, New-Zealand, South Africa).

21 Consequently, the main objective of this paper is to describe the morphology of the two new allanicytidiines from Bolivia and Canada. However, so as to compare them properly with other mitrates, a reevaluation of the two main models of plate homologies elaborated by Ruta (1999a) for supracentrals, and Lefebvre (2001) for adorals and marginals, is a necessary pre- 
125 requisite. Many new data, including previously unrecorded plate patterns, have been

126 accumulated since these two models were proposed, twenty years ago.

134 (Silurian) stratigraphic section (Fig. 1c), and the most complete section known in shelly 135 facies. A long history of stratigraphic and paleontological studies has clarified the geology of 136 Anticosti Island (see e.g. Richardson, 1857; Schuchert and Twenhofel, 1910; Twenhofel, 137 1928; Bolton, 1961; Cocks and Copper, 1981; Petryk, 1981; Long and Copper, 1987; Barnes, 1988; Copper, 1989, 2001; Jin and Copper, 2008; Desrochers et al., 2008, 2010; Copper et al., 2013). Recent investigations have identified the position of the Ordovician-Silurian boundary and, significant to this study, revised the east-west correlation of Aeronian-Telychian

141 stratigraphy based on a combination of biostratigraphy and sequence stratigraphy (Fig. 2;

142 Copper et al., 2013).

144 The new mitrate is from the Cybèle Member of the Jupiter Formation (Telychian; Fig. 2) 145 in eastern Anticosti Island (Fig. 1c). It was collected by the junior author in 2001 from a long, 146 low outcrop along the western bank of the Box River, approximately $700 \mathrm{~m}$ north of the 147 Dauphiné-Bell Road (N 49 $08^{\prime} 53.5^{\prime}$ 'W 62 21' 13.6”). Fossils are relatively abundant in the 148 lithographic limestones of the Cybèle Member. Assemblages are dominated by trilobites, 
149 brachiopods and endemic crinoids, associated to ostracods, tentaculitids, and rare rhenopyrgid 150 edrioasteroids (Ausich and Copper, 2010; Ewin et al., 2020).

\section{Bolivia}

During Devonian times, most of Bolivia was part of an intracratonic basin on the western margin of Gondwana (Isaacson and Díaz-Martinez, 1995; Di Pasquo and Noetinger, 2008). About $50 \mathrm{~km}$ northeast of Sucre (Fig. 3), the classical section of Presto-El Peral exposes the three lowermost units of the Devonian succession in the Eastern Cordillera area (Fig. 4): the Santa Rosa, Icla and Huamampampa formations (Rachebœuf et al., 1993; Gaillard and Rachebœuf, 2006). The Santa Rosa Formation (Lochokovian) is a thick siliciclastic unit consisting mostly of fluvio-deltaic and coastal deposits, yielding abundant land plant remains, associated to rare marine palynomorphs and low diversity trace fossils (Rachebœuf et al., 1993; Gaillard and Rachebœuf, 2006; Di Pasquo and Noetinger, 2008). However, abundant trace fossils (Palaeophycus association) and a relatively diverse, fully marine assemblage

164 occur in the finer-grained sandstones and siltstones of the uppermost part of the Santa Rosa 165 Formation (Rachebœuf et al., 1993; Gaillard and Rachebœuf, 2006). These levels have yielded abundant brachiopods (e.g. Australostrophia sp., Derbyina sp., Proboscidina arcei, Scaphiocoelia boliviensis), associated with asterozoans, bivalves (Nuculites sp., Modiolopsis sp.), crinoid ossicles, gastropods, trilobites and disarticulated vertebrate remains (Rachebœuf 169 et al., 1993; Gaillard and Rachebœuf, 2006; Janvier and Maisey, 2010). Both trace fossils and 170 brachiopods are suggestive of low intertidal environmental conditions (Gaillard and 171 Rachebœuf, 2006). In the early 2000s, fully-articulated remains of two different stylophoran 172 taxa were found by Patrick Rachebœuf in these levels (Gaillard and Rachebœuf, 2006; 173 Lefebvre and Rachebœuf, 2007): a Paranacystis-like mitrocystitid, and the new, herein 
174 described, allanicytidiine mitrate. In the same area, the upper part of the overlying Icla

175 Formation yielded remains of a third, yet undescribed, Placocystites-like anomalocystitine

176 mitrate (Lefebvre and Rachebœuf, 2007). Recent palynological data suggest a Pragian to

177 Emsian age for the shales and siltstones of the Icla Formation (Fig. 4; Troth, 2006; Troth et 178 al., 2011).

\section{MATERIAL AND METHODS}

The material described in this paper is registered in the collections of the Museo de Historia Natural Alcide d'Orbigny, Cochabamba, Bolivia (MHNC) and in the collections of the Geological Survey of Canada, Ottawa, Canada (GSC). Additional specimens illustrated here for comparison purposes are deposited in the paleontological collections of Géosciences Rennes, Rennes 1 University, France (IGR) and Lyon 1 University, Villeurbanne, France (UCBL-FSL).

All five Bolivian specimens are preserved as empty moulds (part and counterpart) in relatively coarse sandstones. Latex casts were made, so as to reveal their original, threedimensional, external aspect. The single specimen from Anticosti is preserved in calcite. Its original morphology is thus immediately accessible, and does not require any casting. All specimens were coated with ammonium chloride $\left(\mathrm{NH}_{4} \mathrm{Cl}\right)$ to enhance contrast for both 194 drawing and photographic purposes. Specimens were observed with a Zeiss SteREO 195 Discovery V8 stereomicroscope binocular, and drawn using a camera-lucida mounted on the same stereomicroscope, at Lyon 1 University. Photographs were made with a Canon 5DSR 197 camera mounted with a MP-E 65mm macro lens. 
The Anticosti specimen is preserved in lower aspect, in close association with a 200 pluricolumnal of Eomyelodactylus with attached rhizoids. In all Siluro-Devonian 201 anomalocystitids, the lower surface of the theca is composed of the same number of skeletal 202 elements: two centrals (anomalocystid and zygal plates) and eleven marginals. Consequently, 203 sub-familial assignment and generic identification relies largely on the plate pattern of the 204 opposite, upper thecal surface (see below). So as to reveal the aspect of its diagnostic upper 205 side, which is inserted in the rock, the Anticosti specimen was examined with a vtomex laboratory X-ray computed tomograph (GE Phoenix | X-Ray GmbH) equipped with a $160 \mathrm{kV}$

207 nano-focus tube, a tungsten transmitting target, and a $1920 \times 1536$ pixel Varian detector, at 208 the Mateis Laboratory, INSA de Lyon. Unfortunately, contrast between the calcite specimen 209 and the surrounding carbonate matrix was too low to visualize any structure hidden in the 210 rock. Ewin et al. (2020) reported a similar, unsuccessful CT-scan experiment made on a 211 specimen of rhenopyrgid edrioasteroid from the same lithostratigraphic unit (Cybèle 212 Member). THECAL PLATE TERMINOLOGY AND HOMOLOGIES

All stylophorans share the same basic body plan, with a single articulated feeding arm

217 (aulacophore) inserted into a polyplated, flattened test (theca), which housed most internal 218 organs (Fig. 5; Ubaghs, 1967a; Chauvel, 1981; Parsley, 1991; Haude, 1995; Ruta, 1999b; 219 David et al., 2000; Lefebvre et al., 2019). The lower side of the theca is generally flat to 220 slightly concave, whereas its upper surface is moderately to highly convex. The two opposite 221 thecal surfaces have distinct plate patterns. 
The lower side (Fig. 5b) is characterized by a frame of thick skeletal elements (marginals), 224 which also forms the lateral walls of the test. In various stylophoran clades, some of these 225 marginals can bear long flattened posterior spikes or be modified into posterior spines (Kirk, 226 1911; Ubaghs, 1967a; Lefebvre, 2001). The number of marginal plates is constant throughout 227 ontogeny, but their respective proportions can be variable (Ubaghs, 1967a). In all 228 stylophorans, an asymmetrical internal structure (the zygal crest or septum) is consistently 229 borne by two plates (forming together the zygal bar or strut), and extends from left of the 230 aulacophore insertion (anteriorly) to right of the anal opening (posteriorly). The marginal 231 frame and the zygal strut delimit two polyplated surfaces: the left and right infracentral areas 232 (Ubaghs, 1967a, 1981; Lefebvre 2001). Both areas are present in most stylophorans, but the 233 right one is frequently lost, independently in various derived taxa (e.g. Anomalocystitidae, 234 Chinianocarpos, Kirkocystidae, Lyricocarpus). The number and shape of infracentral 235 elements are generally highly variable in stylophorans (e.g. Aspidocarpus, Cothurnocystis), 236 but they tend to become constant, independently, in various mitrate taxa (e.g. 237 Anomalocystitidae, Mitrocystella, Paranacystidae, Peltocystis).

The upper thecal surface (Fig. 5a) is characterized by two or three skeletal elements 240 (adorals) forming an anterior bridge framing, with the two underlying anterior marginals, the 241 insertion of the aulacophore into the theca (Ubaghs, 1967a, 1981; Lefebvre et al., 1998). 242 Adorals can form a narrow, delicate adaulacophoral arch (e.g. Ceratocystis, Cothurnocystis) 243 or they can extend posteriorly to form part (e.g. Lagynocystis, Mitrocystites), most 244 (Paranacystis, Peltocystis) and even all of the upper thecal surface (Jaekelocarpus, 245 Kirkocystidae) (Ubaghs, 1967a; Lefebvre, 2001). Their number and relative proportions 246 remain apparently constant during ontogeny. Posteriorly to adorals, the upper side of the theca 247 consists of a large, polyplated integumentary surface (supracentral area). Supracentrals are 
248 generally numerous and unorganized, forming a flexible pavement of tesselate (e.g. 249 Chinianocarpos, Phyllocystis) and/or imbricate elements (e.g. Eumitrocystella, Lagynocystis).

250 In derived mitrocystitidan mitrates (anomalocystitids and paranacystids), supracentral areas 251 consist of a reduced and constant number of elements (Caster, 1952; Ubaghs, 1967a; Parsley, 252 1991; Ruta, 1999a).

253

254 Along with some aulacophore-related features, the morphology and number of major 255 skeletal elements (adorals and marginals) are used as primary key characters for the systematics of stylophorans (Ubaghs, 1967a; Lefebvre, 2001). In derived mitrocystitidans, the

257 identification also relies largely on the number, morphology and position of both infracentrals 258 and supracentrals (Caster, 1952; Ubaghs, 1967a; Parsley, 1991; Ruta, 1999a). Unsurprisingly, 259 various plate nomenclatures have been proposed for stylophorans (e.g. Bather, 1913; Jaekel, 260 1918; Gislen, 1930; Dehm, 1932; Caster, 1952; Ubaghs, 1963; Jefferies, 1968; Jefferies and 261 Prokop, 1972; Philip, 1981; Ruta and Theron, 1997; Ruta and Bartels, 1998; Lefebvre and 262 Vizcaïno, 1999; Ruta, 1999a; Lefebvre, 2000b, 2001). Most of them, however, are either 263 simply descriptive and do not imply any homology (e.g. Jaekel, 1918; Ubaghs, 1963; 264 Jefferies, 1968) and/or can be applied only to a limited group of taxa but not to the whole 265 class Stylophora (e.g. Bather, 1913; Dehm, 1932; Caster, 1952; Philip, 1981; Ruta, 1999a).

In this paper, we largely follow the plate terminology proposed by Lefebvre and Vizcaïno 268 (1999) for cornutes, and extended to mitrates by Lefebvre (2000b, 2001, 2003a). This model 269 implies class-level homologies between major skeletal elements (adorals, marginals), based 270 on their morphology, position, and associated internal structures (Lefebvre et al., 1998; 271 Lefebvre, 2000c, 2001). A similar and complementary plate terminology was elaborated by 272 Ruta (1997b, 1999a) to identify homologies in skeletal elements (adorals, supracentrals) 
273 forming the upper thecal surface of anomalocystitid mitrates (see also Ruta and Theron, 1997;

274 Ruta and Bartels, 1998). These two models are here critically reevaluated and modified, so as

275 to take into account the abundant new data accumulated in the last twenty years and, in

276 particular, those obtained from the late Guzhangian-late Tremadocian time interval (e.g.

277 Sumrall et al., 1997, 2009; Ubaghs, 1998; Smith and Jell, 1999; Sumrall and Sprinkle, 1999;

278 Marti Mus, 2002; Lee et al., 2005; Ware and Lefebvre, 2007; Han and Chen, 2008; Noailles 279 and Lefebvre, 2012; Chen and Han, 2013; Zamora et al., 2013b; Lefebvre et al., 2016; 280 Rozhnov and Parsley, 2017; Peng et al., in press).

281 In the late Cambrian-Early Ordovician interval, stylophorans underwent a major 282 diversification, characterized by a dramatic increase in morphological disparity (Lefebvre et 283 al., 2006) and the emergence of all main post-Cambrian clades (e.g. Amygdalothecidae, 284 Chauvelicystidae, Cothurnocystidae, Hanusiidae, Lagynocystida, Mitrocystitida, Peltocystida, 285 Scotiaecystidae; Lefebvre and Fatka, 2003; Lefebvre, 2007a).

286

Marginals and infracentrals

288

All anomalocystitid mitrates are characterized by a marginal frame made of 11 massive skeletal elements, which can be considered as homologous at the family level (e.g. Dehm, 1932; Caster, 1952, 1954b, 1983; Gill and Caster, 1960; Ubaghs, 1967a, 1979; Jefferies and

292 Lewis, 1978; Philip, 1981; Craske and Jefferies, 1989; Parsley, 1991; Haude, 1995; Ruta, 293 1997b, 1999a; Ruta and Theron, 1997; Ruta and Bartels, 1998; Ruta and Jell, 1999a, 1999c, 294 1999d, 1999e; Lefebvre, 2000b, 2001; Jell, 2013; McDermott and Paul, 2017; Scheffler et al., 295 2019). In all described anomalocystitids, these marginals enclose a large, septum-bearing central plate and a left infracentral area consisting of one ('anomalocystid plate' of Siluro-

297 Devonian taxa) or two elements (Mid-Late Ordovician forms). The right infracentral area is 
absent. Most taxa (with the single exception of Barrandeocarpus) have two posterior movable spines, which have been often interpreted as modified marginals (Kirk, 1911; Ubaghs, 1967a; Jefferies and Lewis, 1978; Parsley, 1991; Lefebvre, 2000b, 2001; but see Jefferies, 1984; Ruta, 1999a).

302

Most of these anomalocystitid skeletal elements (marginals, centrals, spines) can be readily identified in other mitrocystitidans (Jefferies and Lewis, 1978; Craske and Jefferies, 1989; Parsley, 1991; Ruta and Theron, 1997), and more tentatively, at class-level (Lefebvre, 2000b, 2001). The model of stylophoran plate homologies proposed by Lefebvre and Vizcaïno (1999) and Lefebvre (2000b, 2001) interprets Lobocarpus vizcainoi as a basal mitrate, and considers that mitrates derive from a Ceratocystis-like ancestor (Fig. 6a), with large marginals and small infracentral areas. The application of this model to anomalocystitids suggests that:

(1) their left series of marginals corresponds to $M_{1}^{\prime}, M_{2}^{\prime}, M_{3}^{\prime}$, and $M_{4}^{\prime}$; (2) their right marginals can be identified as $\mathrm{M}_{1}, \mathrm{M}_{2}, \mathrm{M}_{3}$, and $\mathrm{M}_{4}$; (3) their two posterior spines are 312 homologous to the digital (D) and the glossal (G); (4) their large central septum-bearing 313 element is the zygal plate (Z); and (5) their three posterior plates correspond to $\mathrm{M}_{5}{ }_{5}$ (on the 314 left) and to two additional platelets of infracentral origin, inserted successively between $\mathrm{M}_{4}$ and $\mathrm{M}_{5}$ (right element $\mathrm{PP}_{1}$ ), and between $\mathrm{PP}_{1}$ and $\mathrm{M}_{5}^{\prime}$ (median element $\mathrm{PP}_{2}$ ).

317 All putative mitrate-like features of the Furongian stylophoran Lobocarpus (e.g. wide 318 marginals, reduced infracentral areas; Fig. 7a) are plesiomorphic, as they occur in 319 Ceratocystis (Fig. 6a), which is almost universally considered as the most basal representative 320 of the class (Ubaghs, 1967b; Jefferies, 1969; Derstler, 1979; Cripps, 1991; Parsley, 1997; 321 Lefebvre and Vizcaïno, 1999; Marti Mus 2002; Ruta, 2003; Lefebvre, 2005; Rahman et al., 322 2010). Moreover, Lobocarpus lacks all apomorphies defining the mitrates: in particular, it 
323 retains small, narrow adorals, and its distal aulacophore is made of unornamented (smooth) 324 ossicles with undifferentiated, flat interbrachial articulations (Ubaghs, 1998). In marked

325 contrast, abundant remains of definitive mitrates have been discovered recently in late 326 Guzhangian to Furongian deposits of Korea (Lefebvre, 2007a) and South China (Chen et al., 327 2013; Zamora et al., 2013b; Zhu et al., 2016; Peng et al., in press).

'Nanocarpus' guoleensis; from the Furongian Guole Biota of South China, was initially described as an amygdalothecid cornute (Chen and Han, 2013). This identification mostly relied on its thecal outlines, a posteriorly open marginal frame (no $\mathrm{M}_{5}-\mathrm{M}_{5}$ bar), the presence 332 of large infracentral areas, a zygal plate in central (not marginal) position, and spikes on the 333 lower surface of brachials. However, its upper surface has two extremely wide adorals (see e.g. Zamora et al., 2013b, fig. 2E). Moreover, well-differentiated interbrachial articulations are present on aulacophore ossicles, allowing the arm to be preserved in recurved position (see e.g. Chen and Han, 2013, figs 2.1-2), which is a typical post-mortem posture of mitrates 337 (Dehm, 1932; Parsley, 1988; Lefebvre, 2003b). All these characters (large adorals, strongly 338 ornamented ossicles with interbrachial articulations) unambiguously support the identification 339 of 'N.' guoleensis as a mitrate, with strong morphological similarities to late Tremadocian taxa 340 such as Chinianocarpos (Fig. 7b) and/or Vizcainocarpus (Fig. 5). The occurrence of other, 341 similar-looking undescribed stylophorans in the late Guzhangian of South China (Peng et al., 342 in press) and the Furongian of Korea (Lefebvre, 2007a) suggests that early mitrates were 343 morphologically closer to Vizcainocarpus (Fig. 5), with large infracentral areas, and a 344 relatively narrow, posteriorly open marginal frame, than to a heavily-plated, Lobocarpus-like 345 form (Fig. 7a). 
In both China and Korea, Cambrian early mitrates are associated to abundant remains of 348 cornute stylophorans with relatively rounded thecal outlines, superficially looking like those 349 of Phyllocystis: e.g. cornute gen. and sp. indet. A (Lee et al., 2005), 'Phyllocystis' jingxiensis 350 (Han and Chen, 2008), and cothurnocystid gen. and sp. indet. (Peng et al. in press, fig. 4A). 351 Very similar-looking forms occur in the Furongian of France (Fig. 8; Ubaghs, 1998, fig. 4), 352 Spain (S. Zamora, pers. comm., Feb. 2016), and the late Tremadocian of Morocco (Lefebvre 353 et al., 2013, fig. 14.17B). All these stylophorans can thus be described as 'P.' jingxiensis-like 354 taxa, with a boot-shaped theca, relatively wide marginals with a flat peripheral flange, large 355 infracentral areas, small adorals, smooth interbrachial articulations, unornamented 356 aulacophore ossicles, and commonly, typical respiratory structures (e.g. cothurnopores) in the 357 right anterior corner of the supracentral area. Their morphology is thus relatively close to that 358 of Flabellicarpus rushtoni (Fig. 6c) from the late Tremadocian of Britain (Marti Mus, 2002). 359 They also share with both Persiacarpos from the late Guzhangian-early Furongian of Iran (Rozhnov and Parsley, 2017) and Ponticulocarpus (Fig. 6b) from the Spence Shale (Wulian) of Utah (Sumrall and Sprinkle, 1999) the possession of particularly enlarged glossal and 362 spinal blades, forming two wide posterior processes. However, 'P.' jingxiensis-like taxa (Fig. 363 8) differ from Persiacarpos and Ponticulocarpus by their posteriorly open marginal frame 364 (loss of the $\mathrm{M}_{5}-\mathrm{M}_{5}$ bar on the lower surface). They also differ from Flabellicarpus (Fig. 6c), Persiacarpos and Ponticulocarpus (Fig. 6b) by their particularly expanded and adjoining 366 glossal and spinal processes. As a consequence of the posterior $\mathrm{M}_{3}{ }_{3}$ (spinal) - $\mathrm{G}$ (glossal) 367 contact, the zygal plate $(Z)$ no longer contributes to the marginal frame but occurs in a central 368 position (Fig. 8). This previously unrecorded plate pattern could explain the origin of central zygal elements in both amygdalothecids (e.g. Amygdalotheca, Nanocarpus) and early mitrates (e.g. 'Nanocarpus' guoleensis, Ovocarpus, Vizcainocarpus). 
The new abundant stylophoran material recently collected in various late Ghuzangian and

373 Furongian localities worldwide suggests that the earliest known mitrates (with a central Z,

374 large infracentral areas, and a posteriorly open marginal frame) were morphologically much

375 closer to Cambrian 'P.' jingxiensis-like cornutes (Fig. 8), than to Lobocarpus-like, heavily-

376 plated stylophorans (Fig. 7a). Consequently, this new evidence questions the possibility that

377 mitrates originated as early as the late Miaolingian from 'P.' jingxiensis-like taxa. If this

378 interpretation is correct, then this would imply that (monophyletic) mitrates derive from

379 paraphyletic, 'cornute-grade' stylophorans (Jefferies, 1968, 1969; Jefferies and Prokop, 1972;

380 Derstler, 1979; Cripps, 1991; Ubaghs, 1991; Parsley, 1991, 1997; Ruta, 2003; but see Gill and

381 Caster, 1960; Ubaghs, 1967a; Lefebvre and Vizcaïno, 1999; Lefebvre, 2001, 2005).

382

383

The 'cornute-grade' origin of mitrates implies that their plate homologies have to be reconsidered. This scenario confirms the identification of the left series of marginals as $\mathrm{M}_{1}{ }_{1}$, $\mathrm{M}_{2}^{\prime}, \mathrm{M}_{3}^{\prime}$ and $\mathrm{M}_{4}^{\prime}$, as well as the homology of the posterior zygal plate in all mitrates, whatever its position: central (e.g. anomalocystitids, Ovocarpus, Vizcainocarpus; Figs 5, 9) or marginal

387 (e.g. Chinianocarpos, Peltocystis; Fig. 7b-c) (Lefebvre et al., 1998; Lefebvre, 2000b, 2000c, 388 2001; Lefebvre and Gutiérrez-Marco, 2003). However, comparison with 'Phyllocystis' jingxiensis-like stylophorans (Fig. 8) suggests that the right series of marginal elements in Vizcainocarpus-like mitrates (including anomalocystitids) should be identified as $\mathrm{M}_{1}, \mathrm{M}_{2}, \mathrm{Mc}$ and $\mathrm{M}_{3}$, rather than as $\mathrm{M}_{1}, \mathrm{M}_{2}, \mathrm{M}_{3}$ and $\mathrm{M}_{4}$ (Figs 5, 7c, 9a). Similarly, the posterior skeletal 392 element inserted between D and G (e.g. Chinianocarpos, Ovocarpus; Figs 7b, 9a) cannot 393 represent $\mathrm{M}_{5}{ }_{5}$, as suggested by Lefebvre $(2000 \mathrm{~b}, 2001)$, because this plate is absent in 'P.' 394 jingxiensis-like stylophorans (Fig. 8) and all known Cambrian mitrates (e.g. 'Nanocarpus' 395 guoleensis). This skeletal element more likely corresponds to an infracentral plate, inserted in 396 between $\mathrm{D}$ and $\mathrm{G}$, and thus closing posteriorly the marginal frame (Figs 7b, 9a). This 
additional posterior element, which is an apomorphy of mitrocystitidan mitrates, is here designated $\mathrm{M}_{6}$.

A similar phenomenon with successive insertions of infracentral elements $\left(\mathrm{PP}_{1}\right.$ and $\left.\mathrm{PP}_{2}\right)$

401 into the posterior margin of mitrocystitidans was proposed by Lefebvre (2000a, 2001, 2003a)

402 to explain the regular increase of their number of marginals from 11 (Ovocarpus), to 12 403 (Aspidocarpus), and 13 (Mitrocystites) (see also Parsley, 1991; Lefebvre and Gutiérrez404 Marco, 2003). This model of homologies suggests that the two posterior plates of Aspidocarpus-like taxa correspond to $\mathrm{M}_{6}$ (on the left) and $\mathrm{PP}_{1}$ (on the right). This identification relies mostly on the growth series of A. bohemicus illustrated by Ubaghs (1979, 407 fig. 2a-e), which suggests that the smallest observed individual has one less marginal (i.e. 11 instead of 12), and that the additional element was inserted in between the glossal and $\mathrm{M}_{6}$ (Lefebvre, 2000b, 2001, 2003a; Lefebvre and Gutiérrez-Marco, 2003). However, the reexamination of Ubaghs' original material of A. bohemicus (Fig. 9b) in the Museum für

411 Naturkunde, Berlin (B. Lefebvre, pers. obs., Nov. 2008) and in particular of the smallest 412 specimen (MB.Ca.114) figured by Ubaghs (1979, fig. 2b) shows that the number of marginals 413 is constant at all growth stages and equal to 12 . Consequently, the growth series of $A$. 414 bohemicus does not have any evidence of insertion of a posterior element during the 415 ontogeny.

417 Comparison with the plate patterns of Ovocarpus-like mitrocystitidans (with 11 marginals; 418 Fig. 9a) suggests that the two posterior plates of Aspidocarpus (Fig. 9b) more likely represent $419 \mathrm{M}_{6}$ (on the right) and an element from the left infracentral area, incorporated into the marginal 420 frame between $\mathrm{M}_{6}$ and $\mathrm{D}$. This new interpretation relies on the similar morphologies (with a 421 strongly rounded posterior edge) and contacts with neighbouring plates ( $\mathrm{G}$ and $\mathrm{Z})$ of $\mathrm{M}_{6}$ in 
both Aspidocarpus and Ovocarpus. Moreover, it seems unlikely that the right posterior plate

423 of Aspidocarpus is the newly added element, because this marginal is not in contact with any

424 of the two polyplated infracentral surfaces: its origin would be unclear (see Lefebvre, 2000b,

425 p. 897). Conversely, it makes more sense to identify the left posterior plate as the newly 426 added element, because it is in direct contact with the left infracentral area. So as to avoid any 427 confusion with the identification proposed by Lefebvre (2000b, 2001, 2003a), the second 428 additional marginal of mitrocystitidan mitrates is here named $\mathrm{M}_{7}$ (Fig. 9b).

In Mitrocystites (Fig. 9c) and other mitrocystitidans with three posterior marginals (e.g. 431 Anomalocystitidae), the right element very likely corresponds to $\mathrm{M}_{6}$, because its shows the 432 same morphology (with a rounded posterior edge) and contacts (with both $\mathrm{G}$ and $\mathrm{Z}$ ) as in 433 Ovocarpus and Aspidocarpus. The identification of the two other posterior plates is more 434 problematic. They are both anteriorly in contact with the left infracentral area, so that any of 435 them can correspond to a plate of infracentral origin inserted into the marginal frame. A first 436 possibility is to consider the skeletal element in median position as an additional plate $\left(\mathrm{PP}_{2}\right)$, 437 inserted between $\mathrm{M}_{6}$ (on the right) and $\mathrm{M}_{7}$ (on the left) (Lefebvre, 2000b, 2001, 2003a). 438 Alternatively, the right posterior plate could be an additional element inserted betwen $\mathrm{M}_{7}$ (on 439 the right) and D (on the left). There are no definitive clues to decipher between these two 440 scenarios. However, two lines of indirect evidence suggest that the second interpretation is 441 more likely (Fig. 9c). First, the teratological specimen of Mitrocystites figured by Lefebvre 442 (2003a, fig. 3D) shows that its right and median posterior plates are both anteriorly in contact 443 with Z, which is similar to the situation in Aspidocarpus, and could support their 444 identification as $\mathrm{M}_{6}$ and $\mathrm{M}_{7}$, respectively. Moreover, in several anomalocystitids, including 445 yet undescribed specimens from the Letná Formation (Sandbian) of Czech Republic (B. 446 Lefebvre, pers. obs.), Protocytidium elliottae (see Ruta and Jell, 1999a), and the two herein 
447 described new allanicytidiines (see below), their median posterior marginal has a strong spike,

448 which is very similar in morphology to the one borne by $\mathrm{M}_{7}$ in Aspidocarpus bohemicus (Fig.

449 9b). For these reasons, the median posterior marginal of Mitrocystites and anomalocystitids is 450 here tentatively identified as $\mathrm{M}_{7}$ (Fig. 9c). Consequently, the left posterior plate of these 451 mitrates is interpreted as an infracentral element inserted between $\mathrm{M}_{7}$ (on the right) and the 452 digital (on the left). So as to avoid any confusion with plate homologies suggested by 453 Lefebvre (2000b, 2001, 2003a), the left posterior plate is here designated $\mathrm{M}_{6}{ }_{6}$ (Fig. 9c). If this interpretation is correct, it would imply that infracentrals $\left(\mathrm{M}_{6}\right.$, then $\mathrm{M}_{7}$, and finally $\left.\mathrm{M}_{6}{ }_{6}\right)$ have been repeatedly inserted into the marginal frame, along the right margin of the digital. This region could represent an area of weakness and/or of reduced mechanical constraints, which 457 might result from the loss of the $\mathrm{M}_{5}-\mathrm{M}_{5}$ bar, which forms the posterior frame of the left 458 infracentral area in other stylophorans (plesiomorphic condition; e.g. Arauricystis, Cothurnocystis, Ponticulocarpus, Protocystites; Fig. 6b).

The nature, origin, and homology of the two posterior spines of anomalocystitid mitrates 462 have been long debated (see e.g. Haeckel, 1896; Kirk, 1911; Caster, 1952; Ubaghs, 1967a; 463 Jefferies and Lewis, 1978; Jefferies, 1984; Parsley, 1991; Ruta, 1999a; Lefebvre 2000b, 2001). Lefebvre $(2000 \mathrm{~b}, 2001)$ suggested that these two spines are homologous to the digital and glossal of cornutes: D and G would have the possibility to be either incorporated in the 466 thecal frame as regular marginals (e.g. Milonicystis, Mitrocystites) or articulated to it and 467 modified as movable spines (e.g. anomalocystidids, Cothurnocystis). In this context, the 468 recent discovery of abundant remains of the earliest, yet undescribed anomalocystitid mitrate in the middle Floian of Morocco (Fig. 10) is particularly informative (Lefebvre, 2007a;

470 Noailles and Lefebvre, 2012; Lefebvre et al., 2013, 2016). Its morphology is a mixture of 471 characters typical of anomalocystitids (e.g. possession of two posterior spines) and 
472 plesiomorphic features widespread in early mitrocystitidans but generally lost in younger

473 anomalocystitids (e.g. lateripores, two polyplated infracentral surfaces, and a supracentral

474 area consisting exclusively of imbricate elements). This new anomalocystitid (Fig. 10) is

475 morphologically very close to Aspidocarpus (Fig. 9b) and Mitrocystites (Fig. 9c). Detailed

476 comparison of the plate patterns of these three mitrates strongly supports the view that Early

477 Ordovician anomalocystitids (with 11 marginals and 2 spines) originated from a

478 Mitrocystites-like form (with 13 marginals), by the modification of two postero-lateral

479 marginals (D and $G$ ) into articulated spines. The new Moroccan mitrate (Fig. 10) thus

480 confirms the homology of posterior spines in all stylophorans (Lefebvre, 2000b, 2001, 2005).

481

482 As in Aspidocarpus (Fig. 9b), the left infracentral area of the new Moroccan mitrate is 483 made of numerous, unorganized platelets (Fig. 10). This observation implies that similar484 looking plate patterns consisting of a reduced number of infracentral elements (1 to 3 ) were 485 acquired independently from irregular, polyplated surfaces in younger anomalocystitids (e.g. 486 Ateleocystites, Barrandeocarpus, Diamphidiocystis, Enoploura; Fig. 11) and in Mitrocystites 487 (Fig. 9c) and related forms (e.g. Eumitrocystella, Mitrocystella, Paranacystidae). 488 Consequently, although they are frequently considered as homologous (e.g. Jefferies and 489 Lewis, 1978; Craske and Jefferies, 1989; Parsley, 1991, 1997; Ruta and Theron, 1997; Ruta, 490 1999a; Lefebvre, 2000b), the two posterior infracentrals occurring in anomalocystitids (Fig. 491 11a-b) and other mitrocystitidans (Fig. 9c) are more likely the result of convergent evolution 492 (reduction of the number of infracentrals) in the two lineages. The terminology introduced by 493 Ruta (1999a) for the two infracentrals in anomalocystitids is retained here, with A for the 494 anterior element, and B for the posterior one (Fig. 11). These letters are convenient, because 495 A is almost universally identified as the 'anomalocystid' plate (e.g. Caster, 1952, 1983; 496 Ubaghs, 1967a, 1979; Philip, 1981; Parsley, 1991; Haude, 1995; Ruta and Bartels, 1998; 
497 Ruta, 1999a; Jell, 2013; Scheffler et al., 2019), and the name 'barrandeocarpid plate' is 498 suggested here for the B element. In Mitrocystites (Fig. 9c) and related mitrocystitidans, the 499 distinct terminology (with $\mathrm{I}_{1}{ }_{1}, \mathrm{I}_{2}{ }_{2}$ and $\mathrm{I}_{3}$ ) introduced by Lefebvre (2003a) should be 500 maintained, so as to avoid any confusion with anomalocystitid infracentrals.

Adorals

503

In anomalocystitids, the anterior margin of the upper thecal surface is invariably consisting of two large skeletal elements, universally considered as homologous at family level (e.g. Dehm, 1932; Caster, 1952, 1954b, 1983; Gill and Caster, 1960; Ubaghs, 1967a, 1979; 507 Jefferies and Lewis, 1978; Kolata and Guensburg, 1979; Philip, 1981; Kolata and Jollie, 508 1982; Jefferies, 1984; Craske and Jefferies, 1989; Rozhnov, 1990; Parsley, 1991, 1997; 509 Haude, 1995; Ruta, 1997b, 1999a; Ruta and Theron, 1997; Ruta and Bartels, 1998; Ruta and Jell, 1999a, 1999c, 1999d, 1999e; Lefebvre, 2000b, 2001; Jell, 2013; McDermott and Paul, 511 2017; Scheffler et al., 2019). These two (left and right) elements can be confidently identified 512 as homologous to the left and right adorals $\left(\mathrm{A}_{1}^{\prime}\right.$ and $\left.\mathrm{A}_{1}\right)$ of other mitrates (Fig. 12b-c), based 513 on the presence of the same internal structures (co-opercula) on their lower (inner) side (see e.g. Chauvel, 1941, 1981; Ubaghs, 1967a, 1979; Jefferies and Lewis, 1978; Kolata and Jollie, 1982; Parsley, 1991, 1997; Lefebvre, 2000b, 2001, 2005). Class-level homology of $A_{1}$ and $A_{1}^{\prime}$

516 (Fig. 12) relies on similarities in position (framing the aulacophore insertion on the anterior 517 edge of the upper thecal side), comparable contacts with the same two underlying marginals $518\left(\mathrm{M}_{1}^{\prime}\right.$ and $\left.\mathrm{M}_{1}\right)$, and also the occurrence of the hydropore on $\mathrm{A}_{1}$ in most cornutes (e.g. Cothurnocystis, Phyllocystis) and basal mitrocystitidans (e.g. Chinianocarpos, Mitrocystites, 520 Ovocarpus, Vizcainocarpus; Fig. 5a) (Ubaghs, 1967a, 1981, 1994; Parsley, 1991, 1997; 521 Lefebvre, 2000b, 2000c, 2001; Lefebvre and Gutiérrez-Marco, 2003). 
523 In the Anomalocystitidae, a third, large anterior skeletal element is present and located

524 either posteriorly to $\mathrm{A}_{1}^{\prime}$ and $\mathrm{A}_{1}$ (in most Anomalocystitinae, e.g. Ateleocystites, 525 Barrandeocarpus, Placocystites) or inserted in between the two adorals and part of the 526 anterior margin of the upper surface (in most Allanicytidiinae, e.g. Enoploura, Placocystella, 527 Protocytidium). Comparison with basal mitrocystitidans indicates that a similar, relatively 528 large median anterior plate is present in most taxa (e.g. Aspidocarpus, Chinianocarpos, 529 Mitrocystites) and is consistently located posteriorly to the two adorals (Ubaghs, 1967a, 1979, 530 1994; Lefebvre, 2000b, 2001). In stylophorans, the plesiomorphic condition for the plating of 531 the anterior margin of the upper surface is illustrated by Ceratocystis (Fig. 12a) and many 532 cothurnocystid-like taxa (e.g. Chauvelicystis, Flabellicarpus, Phyllocystis, Ponticulocarpus), 533 all characterized by three adoral plates $\left(\mathrm{A}^{\prime}{ }_{1}, \mathrm{~A}_{0}\right.$, and $\left.\mathrm{A}_{1}\right)$ that together form an arch above the 534 aulacophore insertion (Ubaghs, 1967a, 1967b, 1970, 1981; Jefferies and Prokop, 1972; 535 Cripps, 1991; Lefebvre and Vizcaïno, 1999; Sumrall and Sprinkle, 1999; Marti Mus, 2002). 536 This plesiomorphic condition with three adorals questions the identification of the median 537 anterior plate of anomalocystitids: this skeletal element has been interpreted either as 538 homologous to the median adoral $\left(\mathrm{A}_{0}\right)$ of basal stylophorans (e.g. Kolata and Jollie, 1982; 539 Parsley, 1991; Haude, 1995; Lefebvre, 2000b, 2001, 2005) or as a distinct plate of 540 supracentral origin, inserted in between $\mathrm{A}_{1}^{\prime}$ and $\mathrm{A}_{1}$ (e.g. Dehm, 1932; Kolata and Guensburg, 541 1979; Ubaghs, 1979).

543 Deciphering the homology of the median anterior plate of anomalocystitids and $\mathrm{A}_{0}$ is a 544 particularly difficult issue, because the median adoral has no characteristic internal features, 545 and this plate was frequently lost, independently, in most stylophoran lineages, as for example 546 in Amygdalothecidae (e.g. Amygdalotheca, Nanocarpus), in derived Chauvelicystidae (e.g. 
Ampelocarpus, Lyricocarpus), in derived Cothurnocystidae (e.g. Cothurnocystis,

548 Procothurnocystis), in Hanusiidae (e.g. Galliaecystis, Hanusia), and in Scotiaecystidae (e.g.

549 Bohemiaecystis, Scotiaecystis) (see e.g. Ubaghs, 1967a, 1970, 1991, 1994; Cripps, 1991;

550 Woods and Jefferies, 1992; Lefebvre and Vizcaïno, 1999; Marti Mus, 2002). Examination of

551 Cambrian 'Phyllocystis' jingxiensis-like stylophorans suggests that $\mathrm{A}_{0}$ was probably present in

552 'P.' jingxiensis (see Han and Chen, 2008), but absent in unassigned Furongian cornutes. from

553 France (see Ubaghs, 1998, fig. 4.3) and Korea (see Lee et al., 2005, figs. 3.3, 4.2). The

554 situation in the earliest known, late Guzhangian-late Tremadocian mitrates is similarly

555 contrasted. Lagynocystids (Furongian-Upper Ordovician; Fig. 12b) are a small clade of

556 morphologically extremely conservative mitrates, characterized by the possession of three

557 large adorals (Ubaghs, 1967a, 1991; Jefferies, 1973; Lefebvre et al., 2010; Zhu et al., 2016;

558 Rozhnov et al., 2019). In contrast, the aulacophore insertions of 'Nanocarpus' guoleensis (late

559 Guzhangian-Furongian, China) and Peltocystis cornuta (late Tremadocian; Fig. 12c) are both

560 framed by only two large adorals (Ubaghs, 1970; Lefebvre and Botting, 2007; Chen et al.,

561 2013). Consequently, the wide expansion of the two lateral adorals in early mitrocystitidans

562 and peltocystidans questions the possible loss of the small, median adoral in these forms.

563

564

In Peltocystis (Fig. 12c), a large skeletal element is consistently present posteriorly to $\mathrm{A}^{\prime}{ }_{1}$

and $A_{1}$. This plate is morphologically indistinct from the surrounding imbricate supracentrals, and also extremely variable in size and shape from one individual to another (see Ubaghs,

567 1967a, 1970; Lefebvre and Botting, 2007). These observations suggest that the large median 568 plate in contact with $\mathrm{A}_{1}^{\prime}$ and $\mathrm{A}_{1}$ in Peltocystis is probably of supracentral origin, which 569 implies that $\mathrm{A}_{0}$ is very likely lost in peltocystidans (see Ubaghs, 1967a, 1970; Lefebvre, 2001;

570 Lefebvre and Botting, 2007). In Chinianocarpos and various other Ordovician 571 mitrocystitidans (e.g. Aspidocarpus, Mitrocystites, new Floian anomalocystitid; Fig. 13a), a 
572 single large skeletal element is also consistently present posteriorly to $\mathrm{A}_{1}{ }_{1}$ and $\mathrm{A}_{1}$. Contrary to

573 the situation in Peltocystis, the size and shape of this median plate are relatively similar from

574 one individual to another (see Ubaghs, 1967a, 1970, 1979; Cripps, 1990). Although it cannot

575 be excluded that this skeletal element in close contact with $\mathrm{A}_{1}^{\prime}$ and $\mathrm{A}_{1}$ corresponds to $\mathrm{A}_{0}$, it is

576 equally possible that it is a distinct plate of supracentral origin. The future descriptions of the

577 Cambrian earliest mitrates will certainly help elucidating the identification of this skeletal 578 element, which will be herein designated as ' $\mathrm{A}_{0}$ ?' in mitrocystitidans (Figs. 13-16), so as to express the uncertainties about its homology with the median adoral of other stylophorans.

Supracentrals

582

All anomalocystitids have similar plate patterns for their lower thecal surface, with consistently the same 14 homologous skeletal elements: four marginals on the left $\left(\mathrm{M}_{1}^{\prime}, \mathrm{M}_{2}^{\prime}\right.$, $\left.\mathrm{M}_{3}^{\prime}, \mathrm{M}_{4}^{\prime}\right)$, four ones on the right $\left(\mathrm{M}_{1}, \mathrm{M}_{2}, \mathrm{Mc}, \mathrm{M}_{3}\right)$, a central zygal (Z), three posterior plates $\left(\mathrm{M}_{6}^{\prime}, \mathrm{M}_{7}, \mathrm{M}_{6}\right.$ ), and two posterior spines (D and $\mathrm{G}$ ) (see above; Fig. 11). In all taxa, but the

587 new Floian anomalocystitid from Morocco, the right infracentral area is absent, and the left 588 one consists of A (Siluro-Devonian forms; Fig. 11c), or A and B (Mid-Late Ordovician taxa; 589 Fig. 11a-b) (see above). Consequently, the systematics of anomalocystitids mostly relies on 590 the plate pattern of their upper thecal surface, and in particular on the number, extent and 591 arrangement of their supracentrals (e.g. Dehm, 1932; Gill and Caster, 1960; Parsley, 1991; 592 Ruta and Theron, 1997; Ruta and Bartels, 1998; Ruta, 1999a; Lefebvre, 2001; McDermott 593 and Paul, 2017). Contrary to the situation in most other stylophorans, anomalocystitid 594 supracentrals are frequently arranged into regular transverse rows, each made of a limited and 595 fixed number of relatively large plates. Various terminologies have been introduced to 596 identify supracentrals in Allanicytidiinae (e.g. Caster, 1952, 1954b; Philip, 1981), 
597 Anomalocystitinae (e.g. Dehm, 1932; Gill and Caster, 1960) or in both groups (e.g. Jefferies 598 and Lewis, 1978; Parsley, 1991). However, the most comprehensive models of plate 599 homologies for the upper thecal surface of anomalocystitids were produced successively by 600 Ruta and Theron (1997), Ruta and Bartels (1998) and Ruta (1999a) (see also Ruta, 1997b; 601 Ruta and Jell, 1999a, 1999c, 1999d, 1999e; Jell, 2013; McDermott and Paul, 2017).

602

603 The terminology elaborated by Ruta (1999a) considers that the supracentrals of all 604 anomalocystitids can be identified from a comparison with the plate pattern of Bokkeveldia oosthuizeni (see Ruta, 1997b; Ruta and Theron, 1997; Ruta and Bartels, 1998). The choice of Bokkeveldia as a reference was justified by the number of transverse supracentral rows (i.e.

607 four, posteriorly to adorals), which is equal (e.g. Victoriacystis), but generally higher than in 608 most other anomalocystitids (e.g. Enoploura, Occultocystis, Placocystella, Placocystites). 609 This model considers that the possession of four regular rows of tesselate supracentrals is the 610 plesiomorphic condition in anomalocystitids, which implies that taxa with three rows have 611 lost one (e.g. Enoploura, Placocystites). This model also largely relies on the parsimonious 612 assumption that standardization of the upper thecal surface occurred only once in 613 anomalocystitids (Ruta, 1999a).

Posteriorly to adorals, the upper surface of the two earliest known anomalocystitids, i.e. the 616 above-mentioned undescribed form from the middle Floian of Morocco (Fig. 13a; Noailles 617 and Lefebvre, 2012) and Diamphidiocystis sp. from the late Darriwilian of France (Fig. 13b; 618 Chauvel, 1981; Lefebvre, 1999, 2000a), consists of numerous imbricate supracentrals forming 619 an irregular, polyplated pavement. Such an unorganized arrangement with imbricate elements 620 (at least in the posterior part of the supracentral area) very likely represents the plesiomorphic 621 condition in anomalocystitids (Lefebvre, 1999). The same plate pattern occurs in various 
other Ordovician mitrates (e.g. Eumitrocystella, Lagynocystis, Peltocystis, Promitrocystites;

623 Fig. 12b-c) (Ubaghs, 1967a).

624

The subfamily Diamphidiocystinae represents a small, highly-distinctive clade of

626 Ordovician anomalocystitids characterized by a markedly sinistrally flexed theca (Kolata and

627 Guensburg, 1979; Chauvel, 1981; Lefebvre, 1999, 2000a, 2001, 2003b; Ruta, 1999a).

628 Contrary to the situation in the Darriwilian form from western France (Fig. 13b), the plate 629 pattern of $D$. drepanon (Katian, Illinois) is characterized by a regular pavement made of few, 630 particularly large, tesselate plates (Kolata and Guensburg, 1979). This observation suggests 631 that the regular arrangement of tesselate supracentrals in D. drepanon derives from an 632 originally unorganized pavement of imbricate elements (Darriwilian Diamphidiocystis). This 633 example implies that comparable plate patterns with few, tesselate supracentrals can be 634 acquired, independently, in various anomalocystitid lineages and, thus, questions the 635 possibility of identifying plate homologies in the two main other clades of the family.

Allanicytidiinae (Fig. 14) are defined by the possession of a distinctive ploughshare-like 638 stylocone with transverse blades (Ubaghs, 1967a; Caster, 1983; Haude, 1995; Lefebvre, 1999, 639 2001; Ruta, 1999a; Ruta and Jell, 1999a; Jell, 2013; Scheffler et al., 2017). Contrary to the 640 situation in most other mitrocystitidans, $\mathrm{A}_{0}$ ? is also generally inserted between $\mathrm{A}_{1}^{\prime}$ and $\mathrm{A}_{1}$, 641 and framing the aulacophore insertion (e.g. Enoploura, Protocytidium, Placocystella; Fig. 642 14a-b). In the earliest known representatives of the subfamily Allanicytidiinae (Enoploura 643 spp., late Sandbian-Katian of North America), the supracentral area has an almost bilaterally 644 symmetrical plate pattern (Fig. 14a), characterized by a fixed number of tesselate elements 645 (11), organized into three incomplete rows (Caster, 1952; Parsley, 1982, 1991). The plate 646 pattern of Enoploura can be readily compared with those of all younger allanicytidiines, and a 
647 well-defined set of homologies can be established at sub-family level (see discussions in 648 Haude, 1995; Ruta and Theron, 1997; Ruta, 1999a; Ruta and Jell, 1999a; Lefebvre, 2001; Jell, 649 2013; Schefller et al., 2017). For example, the reduced number of supracentrals (nine) in 650 Protocytidium elliottae (Hirnantian, Australia; Fig. 14b) most likely results from the loss of 651 two posterior supracentrals (Ruta and Jell, 1999a). Similarly, the plate patterns of 652 Occultocystis (Lower Devonian, Argentina; Fig. 14c) and Placocystella spp. (late 653 Llandovery-early Givetian; Australia, Brazil, New Zealand, South Africa) can be both 654 interpreted as resulting from further drastic reductions of the number of supracentrals from 655 nine elements (Protocytidium) to five and six, respectively (Haude, 1995; Ruta and Theron, 656 1997; Ruta, 1999a; Ruta and Jell, 1999a; Lefebvre, 2001; Jell, 2013; Schefller et al., 2017).

Anomalocystitinae (Figs 15b-c, 16) are characterized by the possession of a highly 659 distinctive supracentral element with rounded to elliptical outlines: the placocystid plate (P). 660 The spineless genus Barrandeocarpus (with an obvious plate $\mathrm{P}$ on its upper thecal surface; 661 Fig. 15b) is thus interpreted here as an anomalocystitine mitrate, in which both D and G have 662 been secondarily lost (Lefebvre, 1999; Lefebvre and Gutiérrez-Marco, 2003; McDermott and 663 Paul, 2017; but see Ubaghs, 1979; Craske and Jefferies, 1989; Ruta, 1997c, 1999a). 664 Anomalocystitines also retain many plesiomorphic mitrocystitidan features, such as 665 longitudinally compressed styloid blades and, in most taxa, a median anterior plate $\mathrm{A}_{0}$ ? 666 located posteriorly to $\mathrm{A}_{1}^{\prime}$ and $\mathrm{A}_{1}$ and, thus, not in contact with the aulacophore insertion (Figs. 667 15b-c, 16a; Lefebvre, 1999). The earliest known representatives of this subfamily, 668 Barrandeocarpus jaekeli (Sandbian, Czech Republic; Fig. 15b), B. sp. (Sandbian, UK), 669 Ateleocystites spp. (early Katian, Canada and USA; Fig. 15c) and A? lansae (late Katian, UK) 670 are all characterized by two anterior, relatively regular rows of supracentrals, each made of a 671 fixed number of elements (Ubaghs, 1979; Kolata and Jollie, 1982; Parsley, 1991; Ruta, 
672 1997c; McDermott and Paul, 2017). In both Ateleocystites and Barrandeocarpus, the most

673 anterior transverse row of supracentrals always comprises five plates, including $\mathrm{P}$ in central

674 position, whereas the next, more posterior row is made of four elements (Fig. 15b-c).

675 However, in some specimens of $A$. huxleyi (and possibly also in some individuals of $B$.

676 jaekeli), a fifth plate can be sometimes more or less deeply inserted posteriorly and in

677 between the two large median supracentrals of the second row (Kolata and Jollie, 1982;

678 Parsley, 1991). In the two genera Ateleocystites (Fig. 15c) and Barrandeocarpus (Fig. 15b),

679 the posterior part of the supracentral area mostly consists of imbricate, irregularly arranged

680 elements in variable number (Ubaghs, 1979; Kolata and Jollie, 1982; McDermott and Paul,

681 2017). In this respect, the very nice reconstructions of both A. guttenbergensis and B. jaekeli

682 provided by Kolata and Jollie (1982, fig. 3) and Ubaghs (1979, fig. 5), respectively, are partly

683 misleading, because they suggest the existence of a more or less regular arrangement for 684 posterior supracentrals, which is not the case. As stated by Kolata and Jollie (1982, p. 640),

685 the total number of supracentrals varies between 20 and 25 in Ateleocystites (i.e. between 11 686 and 16 in the posterior, imbricate region; see also McDermott and Paul, 2017, p. 7).

687

688 The imbricate nature of posterior supracentrals in all known Ordovician anomalocystitines

689 (Ateleocystites, Barrandeocarpus; Fig. 15b-c) suggests that regularization of their upper

690 thecal surface into regular rows of tesselate elements occurred very likely through different 691 processes and later than in coeval Late Ordovician allanicytidiines (Enoploura, 692 Protocytidium; Fig. 14a-b). However, the comparison of the two anterior rows of 693 supracentrals in Ordovician anomalocystitines and allanicytidiines shows several similarities, 694 which could suggest a shared common original pattern of organization into regular rows of 695 tesselate plates. A new terminology is thus tentatively proposed here, so as to facilitate the 
comparison of supracentral plate patterns in early allanicytidiines and anomalocystitines, and also to help identifying putatively homologous skeletal elements.

Similarly to Dehm's terminology (1932), the new system relies primarily on the organization of the upper thecal surface into regular transverse rows of tesselate plates (Figs. 14-15). Within a given row, each plate is assigned a number indicating its position away from the midline, in the same way this is already done for identifying marginals and adorals (see e.g. Lefebvre and Vizcaïno, 1999; Lefebvre, 2001). In all anomalocystitids, the most anterior row (row A) consists of three homologous plates: $\mathrm{A}_{1}{ }_{1}$ (on the left), $\mathrm{A}_{0}$ ? (in median position), and $\mathrm{A}_{1}$ (on the right). In Ordovician anomalocystitines, the next row (here designated as row B) contains five plates, which are from left to right: $\mathrm{B}_{2}{ }_{2}, \mathrm{~B}_{1}{ }_{1}, \mathrm{P}$ (placocystid plate, in median position), $\mathrm{B}_{1}$ and $\mathrm{B}_{2}$ (Fig. 15b-c). Similarly, the second row of supracentrals (row C) typically contains four elements in both Ateleocystites and Barrandeocarpus, with from left to right: $\mathrm{C}_{2}^{\prime}, \mathrm{C}_{1}^{\prime}, \mathrm{C}_{1}$ and $\mathrm{C}_{2}$ (Fig. 15b-c).

Comparison of plate patterns in Ordovician allanicytidiines (Fig. 14a-b) and anomalocystitines (Fig. 15b-c), suggests that supracentrals $\mathrm{C}^{\prime}{ }_{1}$ and $\mathrm{C}_{1}$ in Ateleocystites and Barrandeocarpus are very likely homologous to the pair of similarly shaped, wide median

714 supracentrals anteriorly in contact with $\mathrm{A}_{0}$ ? in both Enoploura and Protocytidium. 715 Comparison with the situation in Ordovician anomalocystitines indicates that the lateral 716 element in contact with both $\mathrm{A}_{1}^{\prime}$ and $\mathrm{C}^{\prime}{ }_{1}$ in Enoploura and Protocytidium can be identified as $717 \mathrm{~B}_{2}$ (same position and same contacts with surrounding plates). Similarly, on the right side of 718 allanicytidiine thecae, $\mathrm{B}_{2}$ corresponds to the supracentral in contact with both $\mathrm{A}_{1}$ and $\mathrm{C}_{1}$ (Fig. 719 14a-b). These identifications imply that, in Enoploura (Fig. 14a) and Protocytidium (Fig. $72014 \mathrm{~b})$, the first row of supracentrals consists of only two plates $\left(\mathrm{B}_{2}{ }_{2}\right.$ and $\left.\mathrm{B}_{2}\right)$, instead of five in 
721 Ordovician anomalocystitines (Fig. 15b-c). In both Enoploura (Fig. 14a) and Protocytidium

722 (Fig. 14b), the absence (loss?) of $\mathrm{B}_{1}{ }_{1}, \mathrm{P}$ and $\mathrm{B}_{1}$ coincides with (and possibly results from) the

723 strong posterior expansion of $\mathrm{A}_{0}$ ? Comparison with Ateleocystites (Fig. 15c) and

724 Barrandeocarpus (Fig. 15b) suggests that the two allanicytidiine lateral supracentrals in

725 contact with $\mathrm{B}_{2}^{\prime}$ and $\mathrm{C}^{\prime}{ }_{1}$, on the one hand, and $\mathrm{B}_{2}$ and $\mathrm{C}_{1}$, and on the other hand, can be

726 reasonably identified as $\mathrm{C}_{2}^{\prime}$ and $\mathrm{C}_{2}$, respectively (Fig. 14a-b).

727

728

In this context, the morphology of the problematic anomalocystitid Willmanocystis

729

denticulatus (early Katian, North America), which is here interpreted as a possible sistertaxon of allanicytidiines (see Kolata and Jollie, 1982; Lefebvre, 1999; but see Parsley, 1991;

731 Ruta, 1999a), is of particular interest. Willmanocystis (Fig. 15a) lacks the distinctive 732 ploughshare stylocone of Allanicytidiinae, but it shares with Enoploura (Fig. 14a) and 733 Protocytidium (Fig. 14b) the possession of an anterior plate $\mathrm{A}_{0}$ ? framing the aulacophore 734 insertion, a supracentral area entirely made of tesselate elements organized into regular rows, 735 and the absence of the placocystid plate. In Willmanocystis (Fig. 15a), supracentrals are 736 numerous (at least 17, more likely 18) and arranged into four transverse rows (Kolata and 737 Jollie, 1982). Comparison with coeval allanicytidiines and anomalocystitines suggests that its 738 first row of supracentrals probably consists of $\mathrm{B}_{2}^{\prime}, \mathrm{B}_{1}{ }_{1}, \mathrm{~B}_{1}$ and $\mathrm{B}_{2}$, thus supporting the view 739 that the two median elements $\left(\mathrm{B}_{1}{ }_{1}\right.$ and $\left.\mathrm{B}_{1}\right)$ were probably lost in Enoploura (Fig. 14a) and 740 Protocystidium (Fig. 14b). In Willmanocystis (Fig. 15a), the next supracentral row is made of 741 five elements, which is unlike the situation in Late Ordovician allanicytidiines and 742 anomalocystitines. The occasional occurrence of a fifth median element $\left(\mathrm{C}_{0}\right.$ ? $)$ inserted in 743 between $\mathrm{C}_{1}$ and $\mathrm{C}_{1}$ in some specimens of Ateleocystites huxleyi (Kolata and Jollie, 1982;

744 Parsley, 1991) and possibly A? lansae (McDermott and Paul, 2017) questions the possibility 745 that the five-plated row of Willmanocystis represents the plesimorphic condition for row $\mathrm{C}$ in 
746 both allanicytidiines and anomalocystitines. Alternatively, this five-plated row might be an 747 autapomorphy of $W$. denticulatus (row absent or lost in e.g. Enoploura and Ateleocystites),

748 and the next, four-plated row could then be equivalent to row $\mathrm{C}$ of Late Ordovician 749 allanicytidiines and anomalocystitines. In Willmanocystis (Fig. 15a), the posterior, regularly 750 arranged row of five tesselate supracentrals has no obvious equivalent in the morphology of 751 coeval anomalocystitines, but it is very likely homologous to the similarly positioned row of 752 Enoploura (Fig. 14a), which is also made of five small plates along the anal opening. The 753 upper surface of Willmanocystis (Fig. 15a) suggests that the arrangement on the upper thecal 754 surface of Enoploura (Fig. 14a) results from a drastic reduction in the number of plates (from 75518 to 11 ) and the probable loss of one row of supracentrals (either the second or the third one, 756 by comparison with $W$. denticulatus; see discussion above). For this reason, the third, 757 posterior supracentral row of Enoploura is here designated E (Fig. 14a), and its five plates, $758 \mathrm{E}_{2}^{\prime}, \mathrm{E}_{1}^{\prime}, \mathrm{E}_{0}, \mathrm{E}_{1}$, and $\mathrm{E}_{2}$ (from left to right). Finally, the plate pattern of the upper thecal surface 759 of Willmanocystis (Fig. 15a) has some troubling similarities with those of much younger, 760 Early Devonian anomalocystitines (e.g. Anomalocystites and, mostly, Bokkeveldia; Fig. 16b). 761 At this stage, it remains difficult to decipher if these similarities in plating are the result of 762 fortuitous convergence or of iterative evolution, possibly due to heterochronic processes.

763

In marked contrast with Ateleocystites (Fig. 15c) and Barrandeocarpus (Fig. 15b), the 765 upper thecal surface of Siluro-Devonian Anomalocystitidae (Fig. 16) is entirely made of 766 tesselate plates with, posteriorly to adorals, three (Placocystites, new undescribed form from 767 Bolivia; Llandovery-Pragian), four (Bokkeveldia, Mongolocarpos, Rhenocystis, 768 Victoriacystis; Ludlow-Emsian), and even five rows (Anomalocystites; Lower Devonian) of 769 regularly arranged supracentrals in fixed number (Dehm, 1932; Gill and Caster, 1960; 770 Ubaghs, 1967a; Jefferies and Lewis, 1978; Rozhnov, 1990; Parsley, 1991; Ruta, 1997b, 
771 1999a; Ruta and Theron, 1997; Ruta and Bartels, 1998; Ruta and Jell, 1999c, 1999d; Lefebvre

772 and Rachebœuf, 2007; Parsley and Sumrall, 2007). Plate patterns of Siluro-Devonian

773 anomalocystitines (Fig. 16) can be easily compared to each other, and a set of robust

774 homologies was proposed by Ruta (1999a; see also Ruta, 1997b; Ruta and Theron, 1997; Ruta

775 and Bartels, 1998). However, the numerical terminology for supracentrals elaborated by Ruta

776 (1999a), which is based on Bokkeveldia, with four rows of plates, posteriorly to adorals (Fig.

777 16b), cannot be applied to taxa such as Anomalocystites, with one more row of supracentrals

778 (Fig. 16c; see Parsley, 1991; Ruta 1999a, fig. 9A).

779

A major issue with Anomalocystitinae lies in the difficulty of comparing the plate patterns 781 of Siluro-Devonian taxa (Fig. 16) with those, very different, of earlier forms (Fig. 15b-c) and, 782 thus, to identify skeletal homologies at subfamily level. In all Anomalocystitinae, row A 783 consists of the same three plates $\left(\mathrm{A}^{\prime}{ }_{1}, \mathrm{~A}_{0}\right.$ ? and $\left.\mathrm{A}_{1}\right)$, and the most anterior row of supracentrals 784 is always made of five skeletal elements, with the highly distinctive placocystid plate in 785 median position (Figs. 15b-c, 16). This implies that the five anterior supracentrals of Siluro786 Devonian anomalocystitines can be readily identified as $\mathrm{B}_{2}{ }_{2}, \mathrm{~B}^{\prime}{ }_{1}, \mathrm{P}, \mathrm{B}_{1}$ and $\mathrm{B}_{2}$. In marked 787 contrast, in the absence of morphologically intermediate forms between Late Ordovician taxa 788 (Ateleocystites, Barrandeocarpus; but see discussion above about Willmanocystis) and 789 younger anomalocystitines, identifying plate homologies posteriorly to row B is almost 790 impossible at present. For example, the current fossil record of Anomalocystitinae provides 791 no clues to decipher if row C of Ateleocystites (Fig. 15c) is lost in Siluro-Devonian taxa (Fig. 792 16) or equivalent to their second or even their third row of supracentrals. Similarly, it is at 793 present impossible to identify which row(s) of tesselate supracentrals in Siluro-Devonian 794 forms are potentially equivalent to the posterior imbricate area of earlier forms. For this 795 reason, a separate nomenclature (with Roman numerals) is provisionally proposed here for the 
four posterior rows of Siluro-Devonian anomalocystitines (Fig. 16). This terminology, which implies row and plate homologies, is kept voluntarily distinct from the above-described nomenclature suggested for Allanicytidiinae and early Anomalocystitinae, because available fossil evidence suggests that the highly standardized plate patterns of their Siluro-Devonian representatives were possibly acquired independently in the two lineages.

801

802

The highest total number of transverse rows (six) is present on the upper thecal surface of 803 Anomalocystites (Fig. 16c; see Ubaghs, 1967a; Parsley, 1991; Ruta, 1999a). Its two anteriormost rows are homologous to rows $\mathrm{A}$ and $\mathrm{B}$ in other anomalocystitids (see above). Although it was not shown on Parsley's reconstruction (1991, fig. 5) of A. cornutus, the placocystid 806 plate is clearly present in median position, within row B (see e.g. Parsley, 1991, pl. 1 figs 4, 807 14; Ruta, 1999a). The next four rows are designated III, IV, V and VI (Fig. 16c). Row and 808 plate homologies in all other Siluro-Devonian anomalocystitines (Fig. 16a-b) can be deduced 809 from a comparison with the upper surface of Anomalocystites (Fig. 16c). Although their fossil 810 record remains relatively sparse, post-Ordovician anomalocystitines seem to show a more or 811 less regular increase of their number of supracentrals through time, and correlatively of their 812 number of transverse rows (Gill and Caster, 1960; but see Ruta and Bartels, 1998): four813 rowed taxa (Fig. 16a) occur in the late Llandovery (A, B, III, and VI; e.g. Placocystites 814 forbesianus), whereas five-rowed ones (Fig. 16b) are not documented before the Ludlow (A, 815 B, III, V, and VI; e.g. Mongolocarpos minzhini, Victoriacystis wilkinsi) and six-rowed forms 816 (Fig. 16c) are only known from the Early Devonian (A, B, III, IV, V, and VI; Anomalocystites 817 cornutus). More data are probably necessary to decipher whether this apparent increase in the 818 number of plates and rows in post-Ordovician anomalocystitines represents an actual trend, or 819 if it simply results from a strong sampling bias. 
SYSTEMATIC PALEONTOLOGY

822

\section{Family Anomalocystitidae Bassler, 1938}

832

Diagnosis. A family of mitrocystitidan mitrates with asymmetrical to symmetrical theca;

834 lower thecal surface comprising 11 marginals, a large plate $\mathrm{Z}$ in central position, and a left 835 infracentral area; digital and glossal modified into posterior spines or secondarily lost; anus 836 opening through a slit or a rake-like anal pyramid with numerous spike-shaped platelets; 837 supracentrals imbricate and/or regularly arranged into transverse rows of tesselate elements; 838 right adoral orifice absent; median element $\mathrm{A}_{0}$ ? posterior to or inserted between $\mathrm{A}_{1}^{\prime}$ and $\mathrm{A}_{1}$; 839 skeletal sculpture more or less extensive on one or both thecal surfaces, consisting of straight 840 to sinuous cuesta-shaped ribs and/or discontinuous scale-like riblets and/or pustules.

842 Remarks. Following Lefebvre (1999, 2000b), anomalocystitids are here considered as a 843 clade within mitrocystitidan mitrates. The diagnosis of Anomalocystitidae has been modified 844 here so as to accomodate their wide morphological disparity and their yet undescribed earliest 845 representative from the middle Floian of Morocco (Figs 10, 13a; Lefebvre, 2007a; Noailles 
and Lefebvre, 2012; Lefebvre et al., 2013, 2016). Three main subdivisions are here identified

847 within anomalocystitids, based on the literature, previous phylogenetic analyses and, mostly,

848 plate homologies: Allanicytidiinae, Anomalocystitinae and Diamphidiocystinae (see above;

849 e.g. Ubaghs, 1967a; Kolata and Guensburg, 1979; Kolata and Jollie, 1982; Parsley, 1991, 850 1997; Ruta, 1999a, 2003; Lefebvre, 2000b, 2001, 2005). The subfamily Allanicytidiinae (Figs

851 11, 14) includes all taxa possessing a ploughshare-shaped stylocone with transverse blades 852 (see below). Anomalocystitines (Figs 15b-c, 16) are defined by the presence of the 853 placocystid plate on their upper thecal surface (see above; Anomalocystites, Ateleocystites, 854 Barrandeocarpus, Bokkeveldia, Mongolocarpos, Placocystites, Rhenocystis, Victoriacystis). 855 Finally, the subfamily Diamphidiocystinae (Fig. 13b) corresponds to a small clade of 856 anomalocystitids with a markedky asymmetrical, sinistrally flexed theca (Diamphidiocystis).

Three Late Ordovician anomalocystitids from North America are not assigned to any subfamily. Willmanocystis denticulatus (Fig. 15a) is a possible sister-taxon of Allanicytidiinae 860 (see discussion above; Kolata and Jollie, 1982). The upper thecal surface of Kopficystis 861 kirkfieldi suggests probable affinities with Anomalocystitinae; the single known specimen of 862 Kopficystis could even represent a poorly preserved individual of Ateleocystites. Similarly, the morphology of the type and only specimen of Kierocystis inserta is extremely poorly known.

864 This genus was defined on the erroneous identification of two tectals (elements of the 865 proximal aulacophore) as a pair of small, additional anterior thecal plates (PSI in Parsley, 866 1991; but see Ruta, 1999a). The plate pattern of its upper thecal surface is anteriorly poorly 867 preserved, so that it is difficult to identify whether one single large median element $\mathrm{A}_{0}$ ? is 868 present (thus suggesting affinities with Enoploura and allanicytidiines), or if this area rather 869 corresponds to four plates (see Ruta, 1999a), with a small $\mathrm{A}_{0}$ ? $, \mathrm{B}^{\prime}{ }_{1}, \mathrm{~B}_{1}$ and possibly, $\mathrm{P}$ (in this 870 case, Kierocystis would be a badly preserved specimen of Ateleocystites). 
874 Diagnosis. A subfamily of anomalocystitid mitrates with a nearly bilaterally symmetrical

875 theca and two posterior spines ( $\mathrm{D}$ and $\mathrm{G}$ ); no right infracentral area; left infracentral area 876 consisting of one or two elements; anus opening through a slit; supracentral area made 877 exclusively of few tesselate plates arranged into two or three transverse rows; no placocystid 878 plate; skeletal sculpture, when present, consisting of discontinuous scale-like riblets and/or 879 pustules; robust ploughshare stylocone with two large transverse blades; proximal ossicles 880 markedly spinose.

Remarks. The diagnosis of the subfamily is emended here, so as to accommodate all 883 genera previously assigned to Allanicytidiinae (Enoploura, Occultocystis, Placocystella, 884 Protocytidium; see Haude, 1995; Ruta and Jell, 1999a), and the two new taxa described 885 herein. As already suggested by Lefebvre (2001), Allanicytidium Caster and Gill in Ubaghs, 886 1967a, Australocystis Caster, 1954b, Notocarpos Philip, 1981 and Tasmanicytidium Caster, 8871983 are here considered junior synonyms of Placocystella Rennie, 1936 (see Lefebvre and 888 Rachebœuf, 2007; Scheffler et al, 2019; but see Jell, 2013). This synonymy is justified by the 889 possession of similarly built thecae, made entirely of the same homologous plates (adorals, 890 marginals and supracentrals). In stylophorans, generic identification relies primarily on the 891 nature and number of their thecal plates. Differences in the shape and/or relative proportions 892 of skeletal elements (i.e. the shorter anterior extent of anomalocystid plate in P. garratti; Fig. 893 11c) are considered as useful characters to discriminate species within a same genus. 
Reexamination by the senior author of the original specimen of anomalocystitid mentioned by Lindström (1888) in the Wenlock of Sweden (see also Regnell, 1945, 1960) indicates that

897 it consists of a partially preserved right adoral $\left(\mathrm{A}_{1}\right)$, some plates of the proximal aulacophore,

898 and an almost complete lower thecal surface. Such remains are generally considered as 899 uninformative for the identification of Siluro-Devonian anomalocystitids (see above). 900 However, Lindström's mitrate has an extensive thecal sculpture consisting of short, 901 discontinuous scale-lile riblets on $\mathrm{A}_{1}$ and numerous pustules on its marginals. This 902 ornamentation suggests allanicytidiine rather than anomalocystitine affinities.

903

904

\section{Genus Perikefalea Lefebvre et Ausich, gen. nov.}

905

906

New genus of allanicytidiine anomalocystitids: Lefebvre and Rachebœuf, 2007, p. 241.

907 New genus of Allanicytidiinae: Scheffler et al., 2019, p. 228.

908

909

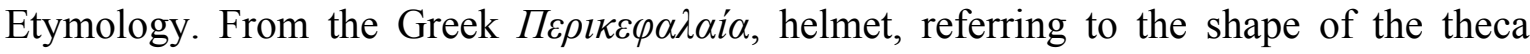

910 (with its highly distinctive posterior median spike), which is similar in the aspect to a

911 Corinthian (hoplite) helmet.

912

Type species. Perikefalea racheboeufi sp. nov. Lefebvre and Ausich.

914

915 Diagnosis. A genus of allanicytidiine mitrate with a long posterior spike on $\mathrm{M}_{7}$; left 916 infracentral area made of one plate (A); upper thecal surface consisting of five extensive 917 skeletal elements; $\mathrm{A}_{0}$ ? diamond-shaped, posteriorly inserted to $\mathrm{A}_{1}{ }_{1}$ and $\mathrm{A}_{1}$, not in conctact 918 with aulacophore insertion; posterior half of upper thecal surface formed by two supracentrals $919\left(\mathrm{C}_{1}^{\prime}\right.$ and $\left.\mathrm{C}_{1}\right)$. 
921 Species composition. Besides the type species, $P$. racheboeufi, another anomalocystitid is 922 also tentatively assigned to Perikefalea: P.? cybeleae sp. nov. Lefebvre and Ausich (late 923 Llandovery, Anticosti Island, Canada).

924

Comparison. The morphology of Perikefalea unambiguously supports its assignment to anomalocystitids (two posterior spines) and, more precisely, to allanicytidiines (ploughshare stylocone with transverse blades). The plating of its upper thecal surface differs from those of most other allanicystidiines in (1) the posterior position of $A_{0}$ ?, which is not in contact with

929 the aulacophore insertion; and (2) the occurrence of only two supracentrals, instead of eleven 930 (Enoploura; Fig. 14a), nine (Protocytidium; Fig. 14b) or six (Placocystella). The morphology 931 of Perikefalea suggests closer affinities with Occultocystis koeneni (Fig. 14c; Lower 932 Devonian, Argentina; Haude, 1995). In both taxa, two pairs of lateral supracentrals are lost $933\left(\mathrm{~B}_{2}^{\prime}-\mathrm{B}_{2}\right.$, and $\left.\mathrm{C}_{2}^{\prime}-\mathrm{C}_{2}\right)$ and $\mathrm{A}_{0}$ ?, occupies a central position, without any contact with the 934 aulacophore insertion. However, Perikefalea differs from Occultocystis by its lower number 935 of supracentrals (two instead of five), resulting from the loss of the three posterior elements $936\left(\mathrm{E}_{1}^{\prime}, \mathrm{E}_{0}\right.$ and $\left.\mathrm{E}_{1}\right)$. The posterior $\mathrm{M}_{7}$ spike of Perikefalea has no equivalent in 937 Anomalocystitidae. A similar $\mathrm{M}_{7}$ spike occurs in Aspidocarpus bohemicus (Fig. 9b; Sandbian, 938 Czech Republic; Ubaghs, 1979). However, the two taxa are not closely related: Perikefalea is 939 a highly derived anomalocystitid, whereas A. bohemicus is a relatively basal mitrocystitidan 940 retaining many plesiomorphic features (e.g. lateripores, digital and glossal incorporated into 941 the marginal frame, two polyplated infracentral areas, polyplated, unorganized supracentral 942 surface). The five-plated upper thecal surface of Perikefalea also shares superficial 943 similarities with the plate pattern of some paranacystids (e.g. Adoketocarpus, Paranacystis; 944 Caster, 1954a; Ubaghs, 1967a; Ruta and Jell, 1999b). Paranacystids are a clade of spineless 
945 mitrocystitidans characterized by a leftward directed anal opening, and a strong expansion of

$946 \mathrm{M}_{6}$, which is modified into a large posterior marginal process (Lefebvre, 1999, 2000b;

947 Lefebvre and Rachebœuf, 2007). Consequently, the similar-looking upper thecal surfaces of

948 paranacystids and Perikefalea were acquired independently, through convergent, drastic

949 reductions of their numbers of supracentrals.

950

951

Perikefalea racheboeufi Lefebvre et Ausich, sp. nov.

952

953

Figs 17-21

954

955

Etymology. The species is named after Patrick Rachebœuf, who collected all the study

956

material from Bolivia and contributed for many years to paleontological and stratigraphic

957 investigations in the Devonian of Bolivia.

958

959

Holotype. MHNC 13354, part and counterpart of an almost complete individual preserved

960 in fine sandstones, and preserving lower and upper thecal surfaces, articulated posterior 961 spines, proximal aulacophore rings, and stylocone (Fig. 17). Uppermost part of the Santa 962 Rosa Formation (Lochkovian, Lower Devonian), Presto-El Peral section, $50 \mathrm{~km}$ NE of Sucre,

963 Bolivia.

964

965 Diagnosis. A species of Perikefalea with a wide, blunt posterior $\mathrm{M}_{7}$ spike, and reticulate 966 thecal plates with no obvious thecal sculpture.

967

968

Description. Relatively broad, almost bilaterally symmetrical theca, with gently curved 969 lateral margins (Fig. 20b-c). Lower thecal surface drop-shaped, with deep, concave, semi- 
970 circular, anterior notch at aulacophore insertion (Fig. 18a-b), and narrow posterior margin

971 with two concave lateral sides separated by a wide, median, spout-like blunt expansion

972 formed by $\mathrm{M}_{7}$ (Figs 17a-b, 18a-b, 19a). Lower thecal surface almost flat, except crescent-

973 shaped raised anterior lip borne by $\mathrm{M}_{1}^{\prime}$ and $\mathrm{M}_{1}$ around aulacophore insertion (Fig. 18a-b), and

974 downward recurved edges of lateral marginals forming two low skate-like flanges on the left

975 (along $\mathrm{M}_{2}^{\prime}, \mathrm{M}_{3}^{\prime}$ and $\mathrm{M}_{4}^{\prime}$ ) and on the right (along $\mathrm{M}_{2}, \mathrm{Mc}$ and $\mathrm{M}_{3}$ ) (Figs 17a-b, 18a-b). Upper

976 thecal surface gently convex, with almost elliptical outlines, and a wide, concave, V-shaped,

977 shallow notch at aulacophore insertion (Figs 17c-d, 18c-d).

978

979

Lower thecal surface consisting of 15 skeletal elements (Figs 20-21): 11 marginals, two

980 plates in central position, and two posterior spines. Anterior marginals $\mathrm{M}_{1}{ }_{1}$ and $\mathrm{M}_{1}$ broad, 981 moderately elongate, subequal in size, entirely forming gently curved anterior edge of lower thecal surface interrupted by deep median notch for aulacophore insertion (Figs 17a-b, 18a-b). Relatively high, vertical, symmetrical aulacophore apophyses borne by anterior walls of $\mathrm{M}_{1}$ 984 and $\mathrm{M}_{1}^{\prime}$, posteriorly to appendage insertion (Fig. 20a). Putative apophyses horns not clearly 985 visible. Next marginals, $\mathrm{M}_{2}^{\prime}$ (on the left) and $\mathrm{M}_{2}$ (on the right), large, fan-shaped, delimited by very short adaxial sutures along $Z$, two longer, strongly diverging, almost straight contacts with neighbouring marginals, and long, gently curved abaxial edges (Figs 17a-b, 18a-b). Next pair of marginals, $\mathrm{M}_{3}^{\prime}$ (on the left) and $\mathrm{Mc}$ (on the right), quadrangular, moderately elongate, 989 slightly shorter than more anterior marginals, with moderately curved abaxial edges and 990 straight sutures along Z (Figs 17a-b, 18a-b, 19a). Next two lateral marginals, $\mathrm{M}_{4}^{\prime}$ (on the left) 991 and $\mathrm{M}_{3}$ (on the right) unequal in size, with slightly different outlines (Figs 17a-b, 18a-b, 19a). $\mathrm{M}_{4}^{\prime}$ and $\mathrm{M}_{3}$ with similar long, almost straight abaxial edges, and very short posterior margin, corresponding to sockets for spine articulation. $\mathrm{M}_{3}$ pentagonal, wider that $\mathrm{M}_{4}^{\prime}$, largely in

994 contact with $\mathrm{Mc}, \mathrm{Z}$ and $\mathrm{M}_{6}$ along straight sutures. $\mathrm{M}_{4}^{\prime}$ with very short suture along $\mathrm{Z}$, concave 
adaxial margin along anomalocystitid plate $\mathrm{A}$, and relatively short, straight contact with $\mathrm{M}_{6}^{\prime}$.

996 Lateral posterior plates $\mathrm{M}_{6}^{\prime}$ (on the left) and $\mathrm{M}_{6}$ (on the right) subequal in size, similarly 997 shaped, elongate, narrow, quadrangular elements, slightly wider posteriorly than anteriorly 998 (Figs 17a-b, 18a-b, 19a). $\mathrm{M}_{6}{ }_{6}$ in contact with $\mathrm{M}_{7}$ (adaxially), $\mathrm{Z}$ (anteriorly), and both $\mathrm{A}$ and

$999 \mathrm{M}_{4}^{\prime}$ (abaxially). $\mathrm{M}_{6}$ sutured to $\mathrm{M}_{3}$ (abaxially), $\mathrm{Z}$ (anteriorly) and $\mathrm{M}_{7}$ (adaxially). Median 1000 posterior marginal $\mathrm{M}_{7}$, particularly elongate, subpentagonal, with short anterior margin in 1001 contact with $\mathrm{Z}$, long, posteriorly diverging, gently concave sutures along $\mathrm{M}_{6}{ }_{6}$ (on the left) and $1002 \mathrm{M}_{6}$ (on the right), and two long marginal edges converging posteriorly towards a blunt, 1003 rounded tip (Figs 17a-b, 18a-b, 19a). Posterior part of $\mathrm{M}_{7}$ thus forming wide, protruding 1004 spike-shaped expansion of marginal frame. Zygal plate particularly large, subhexagonal, 1005 occupying most of central part of lower thecal surface, in contact with anomalocystid plate 1006 and all marginals (Figs 17a-b, 20b). Anomalocystitid plate small central subtrapezoidal 1007 skeletal element in close contact with $\mathrm{M}_{4}^{\prime}$ (abaxially), and also sutured to both Z (adaxially) 1008 and $\mathrm{M}_{6}^{\prime}$ (posteriorly) (Figs 17a-b, 18a-b, 19a). Posterior spines, D (digital, on the left) and G 1009 (glossal, on the right), elongate, rod-shaped, moderately decreasing in width antero1010 posteriorly, with rounded proximal ball for articulation with marginal frame, and distal blunt 1011 extremity (Figs 17a-b, 19a). Digital almost straight, but glossal possibly weakly curved (Figs $101217 a-b, 20 b)$.

1014 Bilaterally symmetrical upper thecal surface (Fig. 20c) entirely made of five large, gently 1015 domed plates: two adorals $\left(\mathrm{A}_{1}^{\prime}\right.$ and $\left.\mathrm{A}_{1}\right)$, one median element $\left(\mathrm{A}_{0}\right.$ ?), and two supracentrals $1016\left(\mathrm{C}_{1}^{\prime}, \mathrm{C}_{1}\right)$. Lateral adorals, $\mathrm{A}_{1}^{\prime}$ (on the left) and $\mathrm{A}_{1}$ (on the right), wide, particularly elongate, 1017 forming together most of anterior half of upper thecal surface (Figs 17c-d, 18c-d). $\mathrm{A}_{1}^{\prime}$ and $\mathrm{A}_{1}$ 1018 with relatively short, straight anterior margins forming wide, shallow, V-shaped, concave 1019 notch above aulacophore insertion. Abaxial margins of lateral adorals particularly elongate, 
convex, regularly curved, closely sutured to lateral walls of underlying marginals $\left(\mathrm{M}_{1}{ }_{1}-\mathrm{M}_{1}\right.$, $\mathrm{M}_{2}{ }_{2}-\mathrm{M}_{2}$ and anterior half of $\mathrm{M}_{3}^{\prime}-\mathrm{Mc}$ ). Adaxial margins of $\mathrm{A}_{1}^{\prime}$ and $\mathrm{A}_{1}$ anteriorly sutured to each other along thecal longitudinal midline, and posterioly diverging abaxially along $\mathrm{A}_{0}$ ?. Each lateral adoral posteriorly in contact with one supracentral along short, straight, transverse 1024 suture. $\mathrm{A}_{0}$ ? large, elongate, diamond- to fan-shaped skeletal element in central position, 1025 sutured to all other plates of upper thecal surface (Figs 17c-d, 18c-d). Maximum width of $\mathrm{A}_{0}$ ? 1026 at contact between adorals and supracentrals. Maximum length of $\mathrm{A}_{0}$ ? along longitudinal

1027 midline. Anterior margins of $\mathrm{A}_{0}$ ?, long, sinous and converging anteriorly to triple junction 1028 with $\mathrm{A}_{1}^{\prime}$ and $\mathrm{A}_{1}$ along thecal longitudinal midline. Posterior margins of $\mathrm{A}_{0}$ ?, much shorter, 1029 gently convex, similarly converging posteriorly to triple junction with $\mathrm{C}_{1}{ }_{1}$ (on the left) and $\mathrm{C}_{1}$ 1030 (on the right) along longitudinal midline. Supracentrals $C_{1}^{\prime}$ and $C_{1}$ almost as extensive as 1031 adorals, particularly elongate, sub-triangular to fan-shaped, forming together most of posterior 1032 half of upper thecal surface (Figs 17c-d, 18c-d). Long, straight, adaxial suture between $\mathrm{C}_{1}$ 1033 and $\mathrm{C}_{1}$ along thecal longitudinal midline. Each supracentral anteriorly in contact with $\mathrm{A}_{0}$ ? and 1034 one lateral adoral. Abaxial margins of $\mathrm{C}_{1}$ and $\mathrm{C}_{1}$ particularly long, convex, regularly flexed, 1035 laterally in contact with underlying marginals (posterior half of $\mathrm{M}_{3}^{\prime}-\mathrm{Mc}, \mathrm{M}_{4}{ }_{4}-\mathrm{M}_{3}$ ), but forming 1036 posteriorly a large vault expanding beyond $\mathrm{M}_{6}^{\prime}$ and $\mathrm{M}_{6}$, up to distal extremity of $\mathrm{M}_{7}$ spike 1037 (Fig. 19a).

Internal thecal features (e.g. infundibulum, septum, scutulae and associated co-opercula) 1040 not observed (all specimens fully articulated, no internal moulds, no isolated plates). Anal 1041 opening slit-like, narrow, in transversely elongate space roofed by $\mathrm{C}_{1}{ }_{1}-\mathrm{C}_{1}$ vault, and floored 1042 by distal margin of posterior marginals $\left(\mathrm{M}_{6}^{\prime}, \mathrm{M}_{7}, \mathrm{M}_{6}\right)$. Internal thecal cavity anteriorly in 1043 contact with lumen of proximal aulacophore through narrow, transversely elongate 
1044 passageway between high aulacophore apophyses borne by $\mathrm{M}_{1}^{\prime}$ and $\mathrm{M}_{1}$ (below) and low vault 1045 provided by $\mathrm{A}_{1}^{\prime}$ and $\mathrm{A}_{1}$ (above) (Fig. 20a).

1046

1047 Proximal aulacophore relatively short, cylindrical, consisting of four telescopic, bilaterally 1048 symmetrical, transverse rings, each made of four plates (Fig. 17): two tectals (above), and two 1049 inferolaterals (below). Left and right series of tectals in contact along longitudinal midline 1050 (Fig. 17c-d). Left and right series of inferolaterals similarly sutured along longitudinal midline 1051 (Fig. 17a-b). Inferolaterals and tectals contributing equally to height of lateral walls of 1052 proximal rings (Fig. 19b). Each ring comprising a slightly narrower, depressed proximal neck, 1053 and a slightly wider, raised distal lip. No intercalated integumentary platelets observed in 1054 between successive rings. Stylocone ploughshare-shaped, with two transverse, oblique blades. 1055 Anterior (distal) stylocone blade much more extensive and wider than posterior (proximal) 1056 one (Figs 17a-b, 19b). Upper surface of stylocone and more distal brachials not observed. In 1057 best preserved aulacophore (Fig. 19b), anterior portion of arm, consisting of more than 20 1058 high, clearly spinose brachials and associated cover plates. Fine details of arm plates obscured 1059 by preservation in coarse siliciclastic deposits.

1060

Measurements. Thecal length (TL) is measured between the anterior-most extremity of 1062 anterior marginals $\left(\mathrm{M}_{1}^{\prime}, \mathrm{M}_{1}\right)$ and the posterior tip of the $\mathrm{M}_{7}$ spike. Thecal width (TW) is 1063 estimated perpendicularly to TL, where width is maximum (i.e. along the $\mathrm{M}_{2}{ }_{2}-\mathrm{M}_{3}$ and $\mathrm{M}_{2}-\mathrm{M}_{3}$ 1064 sutures). Spine length ( $\mathrm{SpL})$ and width $(\mathrm{SpW})$ are measured along and across, respectively, 1065 posterior spines. Maximum width of the stylocone (StylW) is estimated along its anterior 1066 (distal) transverse blade. MHNC 13354 (holotype): TL: $8.5 \mathrm{~mm}$, TW: $5.4 \mathrm{~mm}, \mathrm{SpL}: 3.3 \mathrm{~mm}$, 1067 SpW: $0.6 \mathrm{~mm}$, StylW: $2.6 \mathrm{~mm}$; MHNC 13355: TL: $8.5 \mathrm{~mm}$, TW: $6.2 \mathrm{~mm}$; MHNC 13356: 
1068 TW: $6.2 \mathrm{~mm}$, SpW: $0.6 \mathrm{~mm}$. In the holotype, TW is probably underestimated, because left 1069 marginals are slightly shifted adaxially.

1070

1071

Remarks. The occurrence of a new allanicytidiine mitrate in the Lochkovian of Bolivia

1072 was originally reported by Lefebvre and Rachebœuf (2007), and later mentioned by Scheffler

1073 et al. (2019). Although specimens occur in relatively coarse siliciclastic deposits, the absence 1074 of any obvious external skeletal sculpture is probably original in P. racheboeufi. Minute 1075 details can be preserved, as evidenced by the relatively loose, porous stereom microstructure, 1076 which is visible on most thecal plates and that is similar to the 'punctate' morphology 1077 described in some Ordovician allanicytidiines (e.g. Enoploura punctata; Bassler, 1932; 1078 Parsley, 1991). The absence of ornamentation in P. racheboeufi is possibly related to an 1079 epibenthic, vagile, mode of life, comparable to that of paranacystids occurring in the same 1080 levels of the Santa Rosa Formation (see Lefebvre, 2003b).

In specimen MHNC 13358 (Fig. 19b), the preservation of the arm in extended position is 1083 unusual in mitrates. In this group, the aulacophore is generally recurved over the theca, in a 1084 typical flexed posture, which is usually interpreted as a distressed position or as the result of a 1085 post-mortem contraction (e.g. Dehm, 1932; Jefferies, 1984; Parsley, 1988; Ruta and Bartels, 1086 1998; Lefebvre, 2003b). The unusual preservation of Bolivian anomalocystitids with their 1087 extended arm (i.e. in its original feeding position) suggests that they were very likely buried 1088 alive and in situ by a sudden influx of sediments (see Parsley and Gutiérrez-Marco, 2005; 1089 Lefebvre and Botting, 2007; Martin et al., 2015). Their occurrence in very shallow, low 1090 intertidal deposits suggest that this interpretation is plausible. 
Occurrence. Perikefalea racheboeufi is only known from the type-locality (Presto-El Peral), where it occurs within the uppermost part of the Santa Rosa Formation (Lochkovian).

1094

Material. Besides the holotype (MHNC 13354; Fig. 17), available material comprises four other specimens. MHNC 13355 (Fig. 18) is an almost complete, fully articulated theca, with 1097 the two aulacophore apophyses anteriorly; spines and aulacophore not preserved. MHNC 109813356 (Fig. 19a) preserves the posterior half of a theca, with the pair of spines articulated to 1099 it. The last two individuals, MHNC 13357 and MHNC 13358, are less well-preserved. However, MHNC 13358 (Fig. 19b) corresponds to an almost complete specimen in lateral 1101 position, showing the theca, proximal aulacophore rings, stylocone, and more than 20 1102 brachials and their articulated cover plates; posterior thecal spines not visible.

1103

\section{Perikefalea? cybeleae Lefebvre et Ausich, sp. nov.}

Figs 22-23

1107

1108

Etymology. The species is named after the lithostratigraphic unit (Cybèle Member), where the holotype was collected by the junior author, on Anticosti Island, Canada.

Holotype. GSC 126914 (Figs 22-23), specimen preserved in a fine carbonate mudstone.

1112 Exposed is an almost complete lower thecal surface, part of proximal aulacophore, and a 1113 small portion of distally recurved arm. Cybèle Member of the Jupiter Formation (Telychian, 1114 late Llandovery, Silurian), western bank of the Box River (N 49 08'53.5” W 62॰ 21'13.6”), eastern part of Anticosti Island, Canada. 

thecal sculpture consisting of scale-like riblets.

Description. Almost complete, though slightly disarticulated, lower thecal surface, with drop1121 shaped outlines (Fig 22). Weakly curved, almost straight, abaxial sides. Long, median 1122 posterior process, tapering distally into a sharp spike subdividing posterior margin into two 1123 equal, concave, lateral edges. Anterior thecal margin and aulacophore insertion not preserved. Lower thecal surface almost flat, with the exception of downwards recurved abaxial edges of lateral marginals, forming two low longitudinal skate-like flanges.

Lower thecal surface almost bilaterally symmetrical, with 11 marginals and at least one 1128 plate in a central position (Fig. 23a). Anterior marginals $\mathrm{M}^{\prime}{ }_{1}$ and $\mathrm{M}_{1}$ broad, relatively elongate, subequal in size, and adaxially in contact with each other along straight longitudinal suture (Fig. 22). Precise morphology of aulacophore insertion and anterior margins of $\mathrm{A}_{1}{ }_{1}$ and $\mathrm{A}_{1}$ unknown. Antero-lateral marginals, $\mathrm{M}_{2}^{\prime}$ (on the left) and $\mathrm{M}_{2}$ (on the right), particularly wide, fan-shaped, with elongate, strongly convex abaxial margins (Fig. 22). Anterior portions

1133 of $\mathrm{M}_{2}^{\prime}$ and $\mathrm{M}_{2}$ not preserved. Adaxial margins of $\mathrm{M}_{2}^{\prime}$ and $\mathrm{M}_{2}$ particularly long, sinuous to slightly concave, along sutures with anterior marginals. $\mathrm{M}_{2}^{\prime}$ clearly contacting large central zygal plate $(\mathrm{Z})$ along short, straight suture. Contact between $\mathrm{M}_{2}$ and $\mathrm{Z}$ possible, though not clearly visible. $\mathrm{M}_{2}^{\prime}$ and $\mathrm{M}_{2}$ in contact posteriorly with next pair of lateral marginals, $\mathrm{M}_{3}{ }_{3}$ (on

1137 the left) and $\mathrm{Mc}$ (on the right) along sinuous, transverse sutures. $\mathrm{M}_{3}{ }_{3}$ and $\mathrm{Mc}$, broad, elongate, 1138 both wider anteriorly than posteriorly (Fig. 22). $\mathrm{M}_{3}^{\prime}$ pentagonal, with long, almost straight 1139 abaxial margin, and shorter, sinuous posterior edge sutured to next marginal $\left(\mathrm{M}^{\prime}{ }_{4}\right)$. Adaxial 1140 margin of $\mathrm{M}_{3}^{\prime}$ comprising anteriorly, a long, straight, longitudinal edge probably in contact 1141 with Z, and posteriorly, a shorter, slightly concave, oblique notch along suture with 
anomalocystid plate (A). Mc trapezoidal, delimited by two sinuous, almost parallel, transverse

1143 sutures, anteriorly (with $\mathrm{M}_{2}$ ) and posteriorly (with $\mathrm{M}_{3}$ ), and two longer, almost straight,

1144 markedly diverging edges, adaxially (along contact with Z) and abaxially. Postero-lateral

1145 marginals, $\mathrm{M}_{4}^{\prime}$ (on the left) and $\mathrm{M}_{3}$ (on the right), subequal in size, broad, pentagonal, 1146 significantly shorter than all more anterior marginals (Fig. 22). Posterior edges of both $\mathrm{M}_{4}^{\prime}$ 1147 and $\mathrm{M}_{3}$ particularly short, concave, forming typical sockets for spine insertion. $\mathrm{M}_{4}^{\prime}$ and $\mathrm{M}_{3}$ 1148 both delimited by gently curved abaxial margins, and sinuous sutures with three surrounding 1149 thecal plates. $\mathrm{M}_{3}$ in contact with $\mathrm{Mc}, \mathrm{Z}$ and $\mathrm{M}_{6}$. Anterior portion of $\mathrm{M}_{4}{ }_{4}$ not visible, though 1150 certainly sutured to $\mathrm{M}_{3}^{\prime}$. $\mathrm{M}_{4}^{\prime}$ also in contact with $\mathrm{M}_{6}^{\prime}$ and anomalocystid plate. Lateral 1151 posterior plates, $\mathrm{M}_{6}^{\prime}$ (on the left) and $\mathrm{M}_{6}$ (on the right), subequal in size, narrow, elongate, 1152 slightly shorter anteriorly than posteriorly, with long, subparallel abaxial and adaxial margins 1153 (Fig. 22). $\mathrm{M}_{6}^{\prime}$ anteriorly in contact with anomalocystid plate, and $\mathrm{M}_{6}$, with $\mathrm{Z} . \mathrm{M}_{6}{ }_{6}$ and $\mathrm{M}_{6}$ both adaxially sutured to median posterior plate $\left(\mathrm{M}_{7}\right) . \mathrm{M}_{7}$ relatively broad, wide, pentagonal, with anteriorly, a very short, straight transverse margin, and, two long, gently curved, abaxially 1156 diverging edges along sutures with $\mathrm{M}_{6}^{\prime}$ and $\mathrm{M}_{6}$ (Fig. 22). Posterior margin of $\mathrm{M}_{7}$ expanded 1157 into long spike-shaped median process, with a wide base, strongly concave edges, distally 1158 tapering into a sharp tip. Zygal plate particularly broad, slightly longer than wide, occupying 1159 most of lower thecal surface (Fig. 22). Preserved portion of $\mathrm{Z}$ indicates contacts with most 1160 surrounding marginals $\left(\mathrm{M}_{1}^{\prime}, \mathrm{M}_{1}, \mathrm{M}_{2}^{\prime}, \mathrm{Mc}, \mathrm{M}_{3}, \mathrm{M}_{6}\right.$ ), and possibly with $\mathrm{M}_{2}$ (Fig. 23a). Left and 1161 posterior part of $\mathrm{Z}$ not preserved. Several fragments of skeletal elements (anomalocystid 1162 plate? supracentrals?) occurring between left posterior marginals $\left(\mathrm{M}_{3}^{\prime}, \mathrm{M}_{4}^{\prime}, \mathrm{M}_{6}^{\prime}\right.$ and $\left.\mathrm{M}_{7}\right)$ and 1163 incomplete, visible portion of Z (Fig. 22). Posterior spines not preserved (Fig. 22). shaped areas, almost equally distributed on two marginals, on left $\left(\mathrm{M}_{2}^{\prime}\right.$ and $\left.\mathrm{M}_{3}^{\prime}\right)$ and $\operatorname{right}\left(\mathrm{M}_{2}\right.$ 
1167

1168

1169

1170

1171

1172

1173

1174

1175

1176

1177

1178

1179

1180

1181

1182

1183

1184

1185

1186

1187

1188

1189

1190

1191

and Mc) thecal sides (Fig. 22). Sculpture consisting of irregular, discontinuous, transverse, more or less oblique scale-like riblets. Riblets not parrallel to each other but forming two sets of radiating lines abaxially diverging from two points, located close to the $\mathrm{M}_{2}{ }_{2}-\mathrm{M}_{3}{ }_{3}-\mathrm{Z}$ (on the left) and $\mathrm{M}_{2}-\mathrm{Mc}-\mathrm{Z}$ (on the right) triple contacts. Thecal sculpture not extending, abaxially, into downwards recurved, longitudinal skate-like marginal flanges.

No internal thecal characters visible (specimen showing only external, lower aspect of theca).

Proximal aulacophore consisting of at least four, bilaterally symmetrical proximal rings (Fig. 22). Stylocone and arm not preserved, except small portion of recurved distal aulacophore, consisting of six brachials and five associated cover plates (right series). Three distal-most observed ossicles more or less completely sectioned transversely, with relatively high lateral walls on both sides of deep central part with longitudinal median groove (Fig. 23c). Next two more proximal elements well-preserved, with external aspect of ossicles, with low posterior spike and shallow transverse furrow (Fig. 23c). Sixth, proximal-most brachial poorly preserved. Cover plates incompletely preserved, gently arched, smooth, significantly smaller than associated ossicles (Fig. 23c).

$$
\text { Measurements. GSC } 126914 \text { (holotype): TL: } 14 \mathrm{~mm} \text {, TW: } 8.1 \mathrm{~mm} \text {. }
$$

Remarks. Although posterior spines are not preserved in the Anticosti mitrate (Fig. 22), the presence of typical sockets for spine articulation on the posterior margins of both $\mathrm{M}_{4}{ }_{4}$ and $\mathrm{M}_{3}$ clearly indicates that two spines were originally articulated to the theca (Fig. 23a), thus unambiguously supporting the assignment of this fossil to Anomalocystitidae. The two key 
characters for subfamilial identification (morphology of stylocone blades and plate pattern of

1193 upper thecal) are not available for this specimen (see above, about unsuccessful CT-scan investigations). However, the occurrence of extensive scale-like riblets on lateral marginals $\left(\mathrm{M}_{2}^{\prime}, \mathrm{M}_{3}^{\prime}, \mathrm{M}_{2}\right.$ and $\mathrm{Mc}$; Fig. 22) strongly suggests allanicytidiine, rather than anomalocystitine, affinities. In anomalocystitines, thecal sculpture almost essentially consists of more or less 1197 continuous, straight to sinuous cuesta-shaped ribs and/or pustules, as for exemple in 1198 Ateleocystites (Kolata and Jollie, 1982; Parsley, 1991), Barrandeocarpus (Ubaghs, 1979; 1199 Craske and Jefferies, 1989; Ruta, 1997c; Lefebvre and Gutiérrez-Marco, 2003), Placocystites 1200 (Jefferies and Lewis, 1978), Rhenocystis (Dehm, 1932; Ruta and Bartels, 1998) or 1201 Victoriacystis (Gill and Caster, 1960; Ruta, 1997b; Ruta and Jell, 1999c, 1999d). In contrast, 1202 the external thecal sculpture of allanicytidiines, when present, typically consists either of 1203 discontinuous, crescent-shaped to scale-like riblets and/or of pustules, as in Placocystella 1204 africana (Ruta and Theron, 1997), P. flemingi (Ubaghs, 1967a; Ruta and Jell, 1999e) or P. 1205 garratti (Philip, 1981; Ruta and Jell, 1999e). For this reason, Lindstöm's anomalocystitid 1206 (1888; see discussion above) and the Anticosti mitrate, which both display scale-like riblets 1207 are here identified as probable allanicytidiines.

1208

A further argument supporting this taxonomic assignment of the Anticosti specimen is its 1210 strong similarity with the allanicytidiine genus Perikefalea with, in particular, comparable 1211 morphologies of posterior marginals $\mathrm{M}_{7}$ (strong posterior spike), $\mathrm{M}_{6}{ }_{6}$ and $\mathrm{M}_{6}$ (particularly 1212 narrow and elongate). For this reason, the Anticosti mitrate is interpreted here as a probable 1213 allanicytidiine anomalocystitid, which is tentatively assigned to the genus Perikefalea. To be 1214 confirmed (or not) this identification requires the discovery of additional specimens 1215 preserving the upper thecal surface. Although morphologically very close to P. racheboeufi, 
1216 the Anticosti mitrate is assigned to a distinct species, P.? cybeleae, because of several 1217 differences.

1218

The most obvious difference with $P$. racheboeufi concerns the external thecal sculpture, which is totally absent in P. racheboeufi but extensive in the Canadian form. Moreover, as 1221 ornamentation in anomalocystitids is always stronger on the upper thecal surface (see 1222 Jefferies, 1984; Ruta and Bartels, 1998; Lefebvre, 2003b), the occurrence of widespread 1223 riblets on marginals of $P . ?$ cybeleae suggests that a much more extensive sculpture is present 1224 on its opposite (upper) thecal surface. This strong ornamentation suggests that P.? cybeleae 1225 was very likely infaunal (see Jefferies and Lewis, 1978; Jefferies, 1984; Lefebvre, 2003b).

Other differences concern the morphology of the $\mathrm{M}_{7}$ spike (wider and blunt in $P$. racheboeufi, narrower and sharp in P.? cybeleae), and the relative size of postero-lateral marginals $\mathrm{M}_{4}^{\prime}$ and $\mathrm{M}_{3}$ (much smaller in P.? cybeleae than in P. racheboeufi). Although this is not clearly visible on the holotype (Fig. 22), a single left infracentral element (anomalocystid 1231 plate) was probably present in P.? cybeleae. This interpretation relies on the occurrence of a 1232 relatively large skeletal fragment on the left of $\mathrm{Z}$, and mostly, on the morphology of 1233 surrounding plates $\left(\mathrm{M}_{3}^{\prime}, \mathrm{M}_{4}^{\prime}, \mathrm{M}_{6}{ }_{6}\right.$ and possibly $\left.\mathrm{M}_{7}\right)$, which indicates that they were sutured to 1234 a single, relatively large posterior infracentral element. Moreover, the probable occurrence of 1235 the anomalocystid plate in P.? cybeleae would be in good agreement with the situation in 1236 other Siluro-Devonian anomalocystitids, all charaterized by the loss of the barrandeocarpid 1237 plate (see above). In P.? cybeleae, A is anteriorly largely in contact with $\mathrm{M}_{3}^{\prime}$ (Fig. 23a), which 1238 is not the case in P. racheboeufi (Fig. 21b). 
All these morphological differences are considered here as sufficiently significant to justify

1241 the erection of a distinct species for the Canadian specimen. Finally, all specimens of $P$. 1242 racheboeufi are about twice as smaller and significantly younger (Lochkovian) than the single 1243 known individual of P.? cybeleae (Telychian).

1244

1245 Contrary to the situation in P. racheboeufi (see above), the arm of the only known 1246 specimen of P.? cybeleae is preserved in the typical flexed position (i.e. taphonomic group 2 1247 of Martin et al., 2015). This posture, along with the partial disarticulation of its lower thecal 1248 surface (plates are not in close contact with each other, especially in the posterior part of the 1249 specimen), suggest that the holotype of $P . ?$ cybeleae was not buried alive by a sudden influx 1250 of sediments (e.g. tempestites), but more likely, a short time (several days or weeks) after its 1251 death.

1252

Occurrence. Perikefalea? cybeleae is only known from the type-locality (Box River, 1254 Anticosti Island), where it occurs within the Cybèle Member of the Jupiter Formation 1255 (Telychian).

1256

Material. P.? cybeleae is only known from its holotype.

\section{ACKNOWLEDGMENTS}

1260

1261

This paper is a contribution to the team 'Biosignatures-Vie Primitive' of UMR CNRS 5276

LGLTPE. Field work in Bolivia was supported by the National Geographic Society (grant 1263 6651-99). The authors are particularly grateful to P. Rachebœuf who, during that project, 1264 collected all specimens of $P$. racheboeufi, and provided all necessary information on localities 
1265 and local stratigraphy. This paper is also a continuation of fieldwork supported by the

1266 National Geographic Society (grant 6789-00) and the National Science Foundation (EAR1267 0205968). The holotype of P.? cybeleae was collected on an Anticosti Island excursion with 1268 P. Copper and his students. This study also represents an output of the two European 1269 Synthesys projects DE-TAF-4766 and SE-TAF-4765, which made it possible to examine 1270 specimens discussed in this paper and deposited, respectively, in the collections of the 1271 Museum für Naturkunde, Berlin (Aspidocarpus bohemicus) and the Naturhistoriska 1272 Riksmuseet, Stockholm (Lindström's mitrate). Their respective curators, Christian Neumann 1273 and Christina Franzen-Bengtson, are greatly acknowledged for their help and assistance. The 1274 authors also thank $\mathrm{Xxxxxxx}$ and $\mathrm{Xxxxxxx}$ for their thoughtful reviews. The authors are also 1275 particularly grateful to J. Adrien and C. Salaviale for their help with CT-scan investigations of 1276 the Anticosti material, N. Podevigne and A. Prieur for photographic assistance, and well as N. 1277 Kakavelakis for his help with Ancient Greek. Finally, D. Gendry and E. Robert are thanked 1278 for access to important comparison material deposited in the paleontological collections of 1279 Rennes 1 University and Lyon 1 University, respectively.

\section{REFERENCES}

1283 Ausich, W.I. and Copper, P., The Crinoidea of Anticosti Island, Québec (Late Ordovician to 1284 Early Silurian), Palaeontogr. Can., 2010, vol. 29, pp. 1-157.

1285 Ausich, W.I. and Cournoyer, M.E., New taxa and revised stratigraphic distribution of the 1286 crinoid fauna from Anticosti Island, Québec, Canada (Late Ordovician-early Silurian), $J$. 1287 Paleont., 2019, vol. 93, pp. 1137-1158. 
1288 Barnes, C.R., Stratigraphy and paleontology of the Ordovician-Silurian boundary interval, 1289 Anticosti Island, Québec, Canada, Brit. Mus. Nat. Hist. Bull. (Geol.), 1988, vol. 43, pp. $195-219$.

1291 Bassler, R.S., The stratigraphy of the Central Basin of Tennessee, Div. Geol., Tennessee Bull., $1292 \quad$ 1932, vol. 38, pp. 1-268.

1293 Bassler, R.S., Pelmatozoa Palaeozoica (Generum et Genotyporum Index et Bibliographia), in 1294 Fossilium Catalogus, I, Animalia, pars 83, Quenstedt, W., Ed., 1938, Gravenhage: Verlag $1295 \quad$ Naturwiss., pp. 1-194.

1296 Bather, F.A., Caradocian Cystidea from Girvan, Trans. Roy. Soc. Edinburgh, 1913, vol. 49, $1297 \quad$ pp. $359-529$.

1298 Bolton, T.E., Ordovician and Silurian formations of Anticosti Island, Quebec, Geol. Surv. 1299 Canada Paper, 1961, vol. 71-19, pp. 1-45.

1300 Botting, J.P., Muir, L.A. and Lefebvre, B., Echinoderm diversity and environmental 1301 distribution in the Ordovician of the Builth Inlier, Wales, Palaios, 2013, vol. 28, pp. 293304.

1303 Boucot, A.J., Devonian biogeography: an update, in Devonian of the World, McMillan, N.J., 1304 Embry, A.F. and Glass, D.J., Eds., Proc. Sec. Int. Symp. Dev. Syst. Calgary, 1988, vol. 3, $1305 \quad$ pp. 211-227.

1306 Boucot, A.J. and Rachebœuf, P.R., Biogeographic summary of the Malvinokaffric Realm 1307 Silurian and Devonian fossils, in Fosiles y Facies de Bolivia - vol. II Invertebrados y 1308 Paleobotanica, Suarez-Soruco, R., Ed., 1993, Rev. Técnica YPFB, vol. 13-14, pp. 71-75.

1309 Bruguière, J.G., Tableau Encyclopédique et Méthodique des Trois Règnes de la Nature, 1310 contenant l'Helminthologie, ou les Vers Infusoires, les Vers Intestins, les Vers Mollusques, 1311 etc., Volume 7, 1791, Paris: Panckoucke, pp. 1-180. 
1312 Caster, K.E., Concerning Enoploura of the Upper Ordovician and its relation to other carpoid 1313 Echinodermata, Bull. Amer. Paleont., 1952, vol. 34, pp. 1-47.

1314 Caster, K.E., A new carpoid from the Parana Devonian, Anais Acad. Brasil. Ciencias, 1954a, 1315 vol. 26, pp. 123-147.

1316 Caster, K.E., A Devonian placocystoid echinoderm from Parana, Brazil, in Paleontologia do 1317 Paraná, Lange, F.W., Ed., 1954b, Caritiba: Com. Comemor. Centenario Paraná, pp. 137$1318 \quad 148$.

1319 Caster, K.E., A new Silurian carpoid echinoderm from Tasmania and a revision of the 1320 Allanicytidiidae, Alcheringa, 1983, vol. 7, pp. 321-335.

1321 Caster, K.E. and Eaton, J.R., Microstructure of the plates in the carpoid echinoderm 1322 Paranacystis, J. Paleont., 1956, vol. 30, pp. 611-614.

1323 Chauvel, J., Recherches sur les cystoïdes et les carpoïdes armoricains, Mém. Soc. géol. 1324 minéral. Bretagne, 1941, vol. 5, pp. 1-286.

1325 Chauvel, J., Etude critique de quelques échinodermes stylophores du Massif armoricain, Bull. 1326 Soc. géol. minéral. Bretagne (C), 1981, vol. 13, pp. 67-101.

1327 Chen, G.Y. and Han, N.R., New materials of Stylophora from the Upper Cambrian of the 1328 Jingxi area, Guangxi, South China, Acta Palaeont. Sin., 2013, vol. 52, pp. 288-293.

1329 Cocks, L.R.M. and Copper, P., The Ordovician-Silurian boundary at the eastern end of 1330 Anticosti Island, Canadian J. Earth Sci., 1981, vol. 18, pp. 1029-1034.

1331 Copper, P., Upper Ordovician and Lower Silurian reefs of Anticosti Island, Quebec, 1332 Canadian Soc. Petrol. Geol. Mem, 1989, vol. 13, pp. 271-276.

1333 Copper, P., Reefs during the multiple crises towards the Ordovician-Silurian boundary: 1334 Anticosti Island, eastern Canada, and worldwide, Canadian J. Earth Sci., 2001, vol. 38, pp. $1335 \quad 153-171$. 
1336 Copper, P., Jin, J. and Desrochers, A., The Ordovician-Silurian boundary (late Katian1337 Hirnantian) of western Anticosti Island: revised stratigraphy and benthic megafauna 1338 correlations, Stratigraphy, 2013, vol. 19, pp. 213-227.

1339 Craske, A.J. and Jefferies, R.P.S., A new mitrate from the Upper Ordovician of Norway and a 1340 new approach to subdividing a plesion, Palaeontology, 1989, vol. 32, pp. 69-99.

1341 Cripps, A.P., A new stem-craniate from the Ordovician of Morocco and the search for the 1342 sister group of the Craniata, Zool. J. Linn. Soc., 1990, vol. 100, pp. 27-71.

1343 Cripps, A.P., A cladistic analysis of the cornutes (stem chordates), Zool. J. Linn. Soc., 1991, 1344 vol. 102, pp. 333-366.

1345 David, B., Lefebvre, B., Mooi, R. and Parsley, R., Are homalozoans echinoderms? An answer 1346 from the extraxial-axial theory, Paleobiology, 2000, vol. 26, pp. 529-555.

1347 Dehm, R., Cystoideen aus dem rheinischen Unterdevon, N. Jb. Mineral. Geol. Paläont. Abt. 1348 A, 1932, vol. 69, pp. 63-93.

1349 Dehm, R., Untersuchungen an Cystoideen des rheinischen Unterdevons, Sitz. Bayer. Akad. 1350 der Wiss., Math.-naturwiss.e Abt., 1934, pp. 19-34.

De Koninck, M.L., Sur quelques échinodermes remarquables des terrains paléozoïques, Bull.

1353 Derstler, K., Biogeography of the stylophoran carpoids (Echinodermata), in Historical 1354 Biogeography, Plate Tectonics, and the Changing Environment, Gray, J. and Boucot, A.J., 1355 Eds., 1979, Corvallis: Oregon State University Press, pp. 91-104.

1356 Desrochers, A., Farley, C., Achab, A. and Asselin, E., A high-resolution stratigraphic model 1357 to resolve the longstanding issues relative to the correlation and interpretation of the $\mathrm{O} / \mathrm{S}$ 1358 boundary on Anticosti Island, Canada, in Palaeozoic Climates-International Congress: 1359 Closing meeting of the International Geoscience Programme 503 "Ordovician 
Palaeogeography and Palaeoclimate, Abstracts, Kröger, B. and Servais T., Eds., 2008, 1361 Lille: Univ. Lille, pp. 32.

1362 Desrochers, A., Farley, C., Achab, A., Asselin, E. and Riva, J.F., A far-field record of the end 1363 Ordovician glaciations: the Ellis Bay Formation, Anticosti Island, Eastern Canada, 1364 Palaeogeogr. Palaeoclimatol. Palaeoecol., 2010, vol. 296, pp. 248-263.

1365 Di Pasquo, M.M. and Noetinger, S., First record of Early Devonian (Lochkovian) flora from 1366 the Santa Rosa Formation - Alarache, southern Bolivia, Geol. Acta, 2008, vol. 6, 191-210.

1367 Ewin, T.A.M., Martin, M., Isotalo, P. and Zamora, S., New rhenopyrgid edrioasteroids 1368 (Echinodermata) and their implications for taxonomy, functional morphology, and paleoecology, J. Paleont., 2020, vol. 94, pp. 115-130.

1370 Gaillard, C. and Rachebœuf, P.R., Trace fossils from nearshore to offshore environments: 1371 Lower Devonian of Bolivia, J. Paleont., 2006, vol. 80, pp. 1205-1226.

1372 Gill, E.D. and Caster, K.E., Carpoid echinoderms from the Silurian and Devonian of Australia, Bull. Amer. Paleont., 1960, vol. 41, pp. 5-71.

1374 Gislen, T., Affinities between the Echinodermata, Enteropneusta and Chordonia, Zool. Bidr. 1375 Uppsala, 1930, vol. 12, pp. 199-304.

1376 Guensburg, T.E. and Sprinkle, J., Ecologic radiation of Cambro-Ordovician echinoderms, in 1377 Ecology of the Cambrian Radiation, Zhuravlev, A.Y. and Riding, R., Eds., 2000, New 1378 York: Columbia University Press, pp. 428-444.

1379 Haeckel, E., Die Amphorideen und Cystoideen. Beitrage zur Morphologie und Phylogenie der 1380 Echinodermen, Festschr. Siebenziegsten Geburstage von C. Gegenbaur, 1896, vol. 1, pp. $1381 \quad 32-45$.

1382 Hall, J., Natural History of New York, Paleontology. Vol. III, Containing Descriptions and 1383 Figures of the Organic Remains of the Lower Helderburg Group and the Oriskany 1384 Sandstone. (Part I, Text), 1859, Albany: Van Benthuysen, pp. 1-532. 
1385 Han, N.R. and Chen, G.Y., New stylophorans (Echinodermata) from the Upper Cambrian of 1386 Guangxi, South China, Sci. China Ser. D-Earth Sci, 2008, vol. 51, pp. 181-186.

1387 Haude, R., Kaum bekannte und seltene Echinodermen aus dem Mitteldevon des 1388 rechtsrheinischen Schiefergebirges, Der Aufschluss, 1983, vol. 34, pp. 101-110.

1389 Haude, R., Echinodermen aus dem Unter-Devon der argentinischen Präkordillere, $N . J b$. 1390 Geol. Paläont. Abh., 1995, vol. 197, pp. 37-86.

1391 Isaacson, P.E. and Díaz-Martinez, E., Evidence for a middle-late Paleozoic foreland basin and 1392 significant paleolatitudinal shift, Central Andes, Amer. Ass. Petrol. Geol. Mem., 1995, vol.

\section{4}

Janvier, P. and Maisey, J.G., The Devonian vertebrates of South America and their 1396 biogeographical relationships, in Morphology, Phylogeny and Paleobiogeography of Fossil Fishes, Elliott, D.K., Maisey, J.G., Yu, X. and Miao, D., Eds., 2010, Munich: Verlag Dr. Friedrich Pfeil, pp. 431-460.

Jefferies, R.P.S., The subphylum Calcichordata (Jefferies 1967) primitive fossil chordates with echinoderm affinities, Bull. Brit. Mus. (Nat. Hist.), Geol., 1968, vol. 16, pp. 243-339.

Jefferies, R.P.S. Ceratocystis perneri Jaekel - A Middle Cambrian chordate with echinoderm affinities, Palaeontology, 1969, vol. 12, pp. 494-535.

Jefferies, R.P.S. The Ordovician fossil Lagynocystis pyramidalis (Barrande) and the ancestry

Jefferies, R.P.S, Locomotion, shape, ornament, and external ontogeny in some mitrate calcichordates, J. Vert. Paleont., 1984, vol. 4, pp. 292-319.

Jefferies, R.P.S., The chordates - a preliminary note, in The Arenig Series in South Wales: 
1410 Jefferies, R.P.S. and Lewis, D.N., The English Silurian fossil Placocystites forbesianus and 1411 the ancestry of the vertebrates, Phil. Trans. Roy. Soc. (B), 1978, vol. 282, pp. 205-323.

1412 Jefferies, R.P.S. and Prokop, R.J., A new calcichordate from the Ordovician of Bohemia and 1413 its anatomy, adaptations and relationships, Biol. J. Linn. Soc., 1972, vol. 4, pp. 69-115.

1414 Jell, P., Placocystella in the Early Devonian (Lochkovian) of central Victoria, Alcheringa, 1415 2013, vol. 37, pp. 567-569.

1416 Jin, J. and Copper, P., Response of brachiopod communities to environmental change during 1417 the Late Ordovician mass extinction interval, Anticosti Island, Eastern Canada, Fossils and 1418 Strata, 2008, vol. 54, pp. 41-51.

1419 Kirk, E., The structure and relationships of certain eleutherozoic Pelmatozoa, Proc. U.S. Nat. $1420 \quad$ Mus., 1911, vol. 41, pp. 1-137.

1421 Klein, J.T., Naturalis Dispositio Echinodermatum. Accessit Lucubratiuncula de Aculeis 1422 Echinorum Marinorum, cum Spicilegio de Belemnitis, 1734, Dantzig: Schreiber, pp. 1-79. 1423 Kolata, D.R. and Guensburg, T.E., Diamphidiocystis, a new mitrate "carpoid" from the 1424 Cincinnatian (Upper Ordovician) Maquoketa Group in southern Illinois, J. Paleont., 1979, $1425 \quad$ vol. 53, pp. 1121-1135.

1426 Kolata, D.R. and Jollie, M., Anomalocystitid mitrates (Stylophora-Echinodermata) from the 1427 Champlainian (Middle Ordovician) Guttenberg Formation of the Upper Mississipi Valley 1428 Region, J. Paleont., 1982, vol. 56, pp. 631-653.

1429 Kolata, D.R., Frest, T.J. and Mapes, R.H., The youngest carpoid: occurrence, affinities, and 1430 life mode of a Pennsylvanian (Morrowan) mitrate from Oklahoma, J. Paleont., 1991, vol. $1431 \quad 65$, pp. 844-855.

1432 Lee, S.B., Lefebvre, B. and Choi, D.K., Uppermost Cambrian cornutes (Echinodermata, 1433 Stylophora) from the Taebaeksan Basin, Korea, J. Paleont., 2005, vol. 79, pp. 139-151 
1434 Lefebvre, B., Stylophores (Cornuta, Mitrata): Situation au sein du Phylum des Echinodermes 1435 et Phylogenèse, Lyon: unpubl. PhD thesis, 1999, pp. 1-630.

1436 Lefebvre, B., Les échinodermes stylophores du Massif armoricain, Bull. Soc. Sci. Natur. 1437 Ouest France, 2000a, vol. 22, pp. 101-122.

1438 Lefebvre, B., A new mitrate (Echinodermata, Stylophora) from the Tremadoc of Shropshire 1439 (England) and the origin of the Mitrocystitida, J. Paleont., 2000b, vol. 74, pp. 890-905.

1440 Lefebvre, B., Homologies in Stylophora: a test of the "calcichordate theory", Geobios, 1441 2000c, vol. 33, pp. 359-364.

1442 Lefebvre, B., A critical comment on “ankyroids”, Geobios, 2001, vol. 34, pp. 597-627.

1443 Lefebvre, B., Stephen J. Gould, les mitrates et les monstres, C. R. Palevol, 2003a, v. 2, pp. $1444 \quad 509-522$.

1445 Lefebvre, B., Functional morphology of stylophoran echinoderms, Palaeontology, 2003b, vol. $1446 \quad 46$, pp. 511-555.

1447 Lefebvre, B., Stylophoran supertrees revisited, Acta Palaeont. Pol., 2005, vol. 50, pp. 477$1448 \quad 486$.

1449 Lefebvre, B., Early Palaeozoic palaeobiogeography and palaeoecology of stylophoran 1450 echinoderms, Palaeogeogr. Palaeoclimatol. Palaeoecol., 2007a, vol. 245, pp. 156-199.

1451 Lefebvre, B., Changes in Late Ordovician (pre-Hirnantian) echinoderm assemblages: 1452 palaeoenvironmental and palaeobiogeographical implications, Acta Palaeont. Sin., 2007b, 1453 vol. 46 (suppl.), pp. 241-248.

1454 Lefebvre, B. and Botting, J.P., First report of the mitrate Peltocystis cornuta Thoral 1455 (Echinodermata, Stylophora) in the Lower Ordovician of central Anti-Atlas (Morocco), 1456 Ann. Paléont., 2007, vol. 93, pp. 183-198. 
1457 Lefebvre, B. and Fatka, O., Palaeogeographical and palaeoecological aspects of the Cambro1458 Ordovician radiation of echinoderms in Gondwanan Africa and peri-Gondwanan Europe, 1459 Palaeogeogr. Palaeoclimatol. Palaeoecol., 2003, vol., 195, pp. 73-97.

1460 Lefebvre, B. and Gutiérrez-Marco, J.C., New Ordovician mitrocystitidan mitrates 1461 (Echinodermata, Stylophora) from the Central-Iberian zone (Spain), N. Jb. Geol. Paläont. $1462 \quad$ Abh., 2003, vol. 227, pp. 39-61.

1463 Lefebvre, B. and Rachebœuf, P., First report of mitrate stylophorans (Echinodermata) in the 1464 Lower Devonian of Bolivia, in 4th European Meeting on the Palaeontology and 1465 Stratigraphy of Latin America, Díaz-Martinez, E. and Ríbano, I., Eds., Cuad. Mus. 1466 Geomin., 2007, vol. 8, pp. 239-244.

1467 Lefebvre, B. and Vizcaïno, D., New Ordovician cornutes (Echinodermata, Stylophora) from 1468 Montagne Noire and Brittany (France) and a revision of the Order Cornuta Jaekel 1901, 1469 Geobios, 1999, vol. 32, pp. 421-458.

1470 Lefebvre, B., Rachebœuf, P. and David, B., Homologies in stylophoran echinoderms, in 1471 Echinoderms: San Francisco, Mooi, R. and Telford, M., Eds., 1998, Rotterdam: Balkema, 1472 pp. 103-109.

1473 Lefebvre, B., Eble, J.J., Navarro, N. and David, B., Diversification of atypical Paleozoic 1474 echinoderms: a quantitative survey of patterns of stylophoran disparity, diversity, and 1475 geography, Paleobiology, 2006, vol. 32, pp. 483-510.

1476 Lefebvre, B., Régnault, S., Lardeux, H., Kundura, J.P. and Roussel, P., New Ordovician 1477 mitrates (Echinodermata, Stylophora) from the Ancenis Basin (South Armorican Domain, 1478 France): palaeogeographic and palaeoenvironmental implications, in Echinoderms: 1479 Durham, Harris, L.G., Böttger, S.A., Walker, C.W. and Lesser, M.P., Eds., 2010, Leiden: $1480 \quad$ Balkema, 37-44. 
1481 Lefebvre, B., Sumrall, C.D., Shroat-Lewis, R.A., Reich, M., Webster, G.D., Hunter, A.W., 1482 Nardin, E., Rozhnov, S.V., Guensburg, T.E. and Touzeau, A., Palaeobiogeography of 1483 Ordovician echinoderms, in Early Palaeozoic Biogeography and Palaeogeography, 1484 Harper, D.A.T and Servais, T., Eds, Geol. Soc. London Mem., 2013, vol. 38, pp. 173-198.

1485 Lefebvre, B., Allaire, N., Guensburg, T.E., Hunter, A.W., Kouraïss, K., Martin, E.L.O., 1486 Nardin, E., Noailles, F., Pittet, B., Sumrall, C.D. and Zamora, S., Palaeoecological aspects 1487 of the diversification of echinoderms in the Lower Ordovician of central Anti-Atlas, 1488 Morocco, Palaeogeogr. Palaeoclimatol. Palaeoecol., 2016, vol. 460, pp. 97-121.

1489 Lefebvre, B., Guensburg, T.E., Martin, E.L.O., Mooi, R., Nardin, E., Nohejlová, M., Saleh, 1490 F., Kouraïss, K., El Hariri, K. and David, B., Exceptionally preserved soft parts in fossils 1491 from the Lower Ordovician of Morocco clarify stylophoran affinities within basal 1492 deuterostomes, Geobios, 2019, vol. 52, pp. 27-36.

1493 Lindström, G., List of the Fossil Faunas of Sweden, Part 2, Upper Silurian, 1888, Stockholm: $1494 \quad$ Norstedt \& Söner, pp. 1-29.

1495 Long, D.G.F. and Copper, P., Stratigraphy of the Upper Ordovician upper Vauréal and Ellis 1496 Bay formations, eastern Anticosti Island, Québec, Canadian J. Earth Sci., 1987, vol. 24, 1497 pp. $1807-1820$.

1498 Marti Mus, M., The Ordovician cornute Flabellicystis rushtoni n. gen. n. sp. (Stylophora, 1499 Echinodermata) and its phylogenetic position within the group Cornuta, Paläont. Z., 2002, $1500 \quad$ vol. 76, pp. 99-116.

1501 Martin, E.L.O., Lefebvre, B. and Vaucher, R., Taphonomy of a stylophoran-dominated 1502 assemblage in the Lower Ordovician of Zagora area (central Anti-Atlas, Morocco), in 1503 Progress in Echinoderm Palaeobiology, Zamora, S. and Rabano, I., Eds., Cuadernos del 1504 Museo Geominero, 2015, vol. 19, pp. 95-100. 
1505 McDermott, P.D. and Paul, C.R.C., Ateleocystites? lansae sp. nov. (Mitrata, 1506 Anomalocystitidae) from the Upper Ordovician of South Wales, Geol. Mag., 2017, vol. 52, 1507 pp. $1-13$.

1508 Noailles, F. and Lefebvre, B., A New Mitrate Stylophoran from the Lower Ordovician of the 1509 Central Anti-Atlas (Morocco) and the Origin of the Anomalocystitids, Brussels: 1510 Conference booklet, 14th International Echinoderm Conference, 2012, pp. 63.

1511 Parsley, R.L., Homalozoans, in Echinoderm Faunas from the Bromide Formation (Middle 1512 Ordovician) of Oklahoma, Sprinkle, J., Ed., Univ. Kansas Paleont. Contrib. Monogr., 1513 1982, vol. 1, pp. 322-323.

1514 Parsley, R.L., Feeding and respiratory strategies in Stylophora, in Echinoderm Phylogeny and 1515 Evolutionary Biology, Paul, C.R.C. and Smith, A.B., Eds., 1988, Oxford: Clarendon Press, $1516 \quad$ pp. $347-361$.

1517 Parsley, R.L., Review of selected North American mitrate stylophorans (Homalozoa: 1518 Echinodermata), Bull. Amer. Paleont., 1991, vol. 100, pp. 5-57.

1519 Parsley, R.L., The echinoderm classes Stylophora and Homoiostelea: non Calcichordata. 1520 Paleont. Soc. Papers, 1997, vol. 3, pp. 225-248.

1521 Parsley, R.L. and Gutiérrez-Marco, J.C., Stylophorans in middle Arenig shallow water 1522 siliciclastics: Vizcainocarpus from the Imfout syncline in Morocco's western Meseta, Bull. 1523 Geosci., 2005, vol. 80, pp. 185-192.

1524 Parsley, R.L. and Sumrall, C.D., New recumbent echinoderm genera from the Bois d'Arc 1525 Formation: Lower Devonian (Lochkovian) of Coal County, Oklahoma, J. Paleont., 2007, 1526 vol. 81, pp. 1486-1493.

1527 Peng, S.C., Yang, X.F., Liu, Y., Zhu, X.J., Sun, H.J., Zamora, S., Mao, Y.Y. and Zhang, Y.C., 1528 Fulu Biota, a new exceptionally-preserved Cambrian fossil assemblage from the Longha 1529 Formation in southeastern Yunnan, Palaeoworld, in press. 
1530 Penn-Clarke, C.R., The Malvinokaffric Realm in the Early-Middle Devonian of South Africa, 1531 J. Afr. Earth Sci., 2019, vol. 158 (103549), pp. 1-19.

1532 Petryk, A.A., Stratigraphy, sedimentology, and paleogeography of the Upper Ordovician1533 Lower Silurian of Anticosti Island, Québec, in Field Meeting Anticosti-Gaspé, Québec, 1534 Lespérance, P.J., Ed., Montréal: Subcomm. Silurian Stratigr., Ordovician-Silurian 1535 Boundary Working Group., 1981, vol. 2, pp. 10-39.

1536 Philip, G.M, Notocarpos garratti gen. et sp. nov., a new Silurian mitrate carpoid from 1537 Victoria, Alcheringa, 1981, vol. 3, pp. 29-38.

1538 Prokop, R.J., Dalejocystis n. gen. the first representative of the Carpoidea in the Devonian of 1539 Bohemia, J. Paleont., 1963, vol. 37, pp. 648-650.

1540 Rachebœuf, P.R., Le Hérissé, A., Paris, F., Babin, C., Guillocheau, F., Truyols-Massoni, M. 1541 and Súarez-Soruco, R., Le Dévonien de Bolivie: biostratigraphie et chronostratigraphie, $C$. 1542 R. Acad. Sci. Paris, 1993, vol. 317, pp. 795-802.

1543 Rahman, I.A., Zamora, S. and Geyer, G., The oldest stylophoran echinoderm: a new 1544 Ceratocystis from the Middle Cambrian of Germany, Paläont. Z., 2010, vol. 84, pp. 2271545237.

1546 Régnault, S. and Chauvel, J., Découverte d'un échinoderme carpoïde (Stylophora - Mitrata) 1547 dans le Dévonien inférieur du Maroc, Geobios, 1987, vol. 20, pp. 669-674.

1548 Regnell, G., Non-crinoid Pelmatozoa from the Paleozoic of Sweden. A taxonomic study, 1549 Medd. Lunds Geol. Mineral. Inst., 1945, vol. 108, pp. 1-255.

1550 Regnell, G., The Lower Palaeozoic echinoderm faunas of the British Isles and Balto-Scandia, 1551 Palaeontology, 1960, vol. 2, pp. 161-179.

1552 Reich, M., Lefebvre, B. and Kutscher, M., Mitrates (Echinodermata: Stylophora) from the 1553 Silurian of Gotland, Sweden, in The Seventh Baltic Stratigraphical Conference. Abstracts 
\& Field Guide, Hints, O., Ainsaar, L., Männik, P. and Meidla, T., Eds., 2008, Tallinn: $1555 \quad$ Geol. Soc. Estonia, pp. 58.

1556 Reid, M., Bordy, E.M. and Taylor, W., Taphonomy and sedimentology of an echinoderm 1557 obrution bed in the Lower Devonian Voorstehoek Formation (Bokkeveld Group, Cape 1558 Supergroup) of South Africa, J. Afr. Earth Sci., 2015, vol. 110, pp. 135-149.

1559 Rennie, J.V.L., On Placocystella, a new genus of cystids from the Lower Devonian of South 1560 Africa, Ann. South Afr. Mus., 1936, vol. 31, pp. 269-275.

1561 Richardson, J., Report of the year 1856, Canadian Surv. Report Progr. 1853-54-55-56, 1562 1857, pp. 191-245.

1563 Rozhnov, S.V., New representatives of the class Stylophora (echinoderms), Paleont. J., 1990, $1564 \quad$ vol. 4, pp. 27-38.

1565 Rozhnov, S.V. and Parsley, R.L., A new cornute (Homalozoa: Echinodermata) from the 1566 uppermost middle Cambrian (Stage 3, Furongian) from northern Iran: its systematics and functional morphology, Paleont. J., 2017, vol. 51, pp. 500-509.

1568

Rozhnov, S.V., Mirantsev, G.V., and Terentiev, S.S., First report of the mitrate Lagynocystis 1569 (Echinodermata: Stylophora) in the Ordovician of the Baltic paleobasin, Zoosymposia, 2019, vol. 15, pp. 115-122.

1571 Ruta, M., First record of a paranacystid mitrate from the Bokkeveld Group of South Africa, Palaeont. Afr., 1997a, vol. 34, pp. 15-25.

1573 Ruta, M., Redescription of the Australian mitrate Victoriacystis with comments on its 1574 functional morphology, Alcheringa, 1997b, vol. 21, pp. 81-101.

1575 Ruta, M., First record of the mitrate Barrandeocarpus from England, Paläont. Z, 1997c, vol. 1576 71, pp. 97-105.

1577 Ruta, M., A new mitrate from the Lower Ordovician of southern France, Palaeontology, $1578 \quad$ 1997d, vol. 450, pp. 363-383. 
1579 Ruta, M., A cladistic analysis of the anomalocystitid mitrates, Zool. J. Linn. Soc., 1999a, vol. $1580 \quad 127$, pp. 345-421.

1581 Ruta, M., A new stylophoran echinoderm, Juliaecarpus milnerorum, from the Late 1582 Ordovician Upper Ktaoua Formation of Morocco, Bull. Nat. Hist. Mus., London (Geol.), $1583 \quad 1999 b$, vol. 55, pp. 47-79.

1584 Ruta, M., A species-level supertree for stylophoran echinoderms. Acta Palaeont. Pol., 2003, 1585 vol. 48, pp. 559-568.

1586 Ruta, M. and Bartels, C., A redescription of the anomalocystitid mitrate Rhenocystis 1587 latipedunculata from the Lower Devonian of Germany, Palaeontology, 1998, vol. 41, pp. $1588 \quad 771-806$.

1589 Ruta, M. and Jell, P., Protocytidium gen. nov., a new anomalocystitid mitrate from the 1590 Victorian Latest Ordovician and evolution of the Allanicytidiidae, Mem. Queensland Mus., 1591 1999a, vol. 43, pp. 353-376.

1592 Ruta, M. and Jell, P., Adoketocarpus gen. nov., a mitrate from the Ludlovian Kilmore 1593 Siltstone and Lochkovian Humevale Formation of central Victoria, Mem. Queensland 1594 Mus., 1999b, vol. 43, pp. 377-398.

1595 Ruta, M. and Jell, P., Two new anomalocystitid mitrates from the Lower Devonian Humevale 1596 Formation of central Victoria, Mem. Queensland Mus., 1999c, vol. 43, pp. 399-422.

1597 Ruta, M. and Jell, P., A note on Victoriacystis wilkinsi (Anomalocystitidae: Mitrata) from the 1598 Upper Silurian of Victoria, Mem. Queensland Mus., 1999d, vol. 43, pp. 423-430.

1599 Ruta, M. and Jell, P., Revision of Silurian and Devonian Allanicytidiidae (Anomalocystitida: 1600 Mitrata) from southeastern Australia, Tasmania and New-Zealand, Mem. Queensland 1601 Mus., 1999e, vol. 43, pp. 431-451.

1602 Ruta, M. and Theron, J.N., Two Devonian mitrates from South Africa, Palaeontology, 1997, 1603 vol. 40, pp. 201-243. 
1604 Scheffler, S.M., Horodyski, R.S. and Bosetti, E.P., Morphology, palaeoecology and 1605 taphonomy of the Devonian mitrate Placocystella langei from Paraná Basin, Brazil, 1606 Alcheringa, 2019, vol. 43, pp. 228-240.

1607 Schuchert, C. and Twenhofel, W.H., Ordovicic-Siluric section of the Mingan and Anticosti 1608 islands, Gulf of St. Lawrence, Geol. Soc. Amer. Bull., 1910, vol. 21, pp. 677-716.

1609 Smith, A.B. and Jell, P.A., A new cornute carpoid from the Upper Cambrian (Idamean) of 1610 Queensland, Mem. Queensland Mus., 1999, vol. 43, pp. 341-350.

1611 Sumrall, C.D. and Sprinkle, J., Ponticulocarpus, a new cornute-grade stylophoran from the 1612 Middle Cambrian Spence Shale of Utah, J. Paleont., 1999, vol. 73, pp. 886-891.

1613 Sumrall, C.D., Sprinkle, J. and Guensburg, T.E., Systematics and paleocology of Late 1614 Cambrian echinoderms from the western United States, J. Paleont., 1997, vol. 71, pp. $1615 \quad 1091-1109$.

1616 Sumrall, C.D., Sprinkle, J., Pruss, S. and Finnegan, S., Cardiocystella, a new cornute 1617 stylophoran from the Upper Cambrian Whipple Cave Formation, eastern Nevada, USA, $J$. 1618 Paleont., 2009, vol. 83, pp. 307-312.

1619 Troth, I., The Applications of Palynostratigraphy to the Devonian of Bolivia, Southampton: $1620 \quad$ Unpubl. PhD thesis, 2006, 1-204.

1621 Troth, I., Marshall, J.E.A., Racey, A. and Becker, R.T., Devonian sea-level change in Bolivia: 1622 a high palaeolatitude biostratigraphical calibration of the global sea-level curve, 1623 Palaeogeogr. Palaeoclimatol. Palaeoecol., 2011, vol. 304, pp. 3-20.

1624 Twenhofel, W.H., Geology of Anticosti Island, Geol. Surv. Canada Mem.,1928, vol. 154, pp. $1625 \quad 1-481$.

1626 Ubaghs, G., Cothurnocystis Bather, Phyllocystis Thoral and an undetermined member of the 1627 order Soluta (Echinodermata, Carpoidea) in the uppermost Cambrian of Nevada, $J$. 1628 Paleont., 1963, vol. 37, 1133-1142. 
1629 Ubaghs, G., Stylophora, in Treatise on Invertebrate Paleontology: Part S. Echinodermata 1630 1(2), Moore, R.C., Ed., Boulder: Geol. Soc. Amer., Boulder, and Lawrence: Univ. Kansas $1631 \quad$ Press, 1967a, pp. S495-S565.

1632 Ubaghs, G. Le genre Ceratocystis Jaekel (Echinodermata, Stylophora), Univ. Kansas Paleont. 1633 Contrib., 1967b, vol. 22, pp. 1-16.

1634 Ubaghs, G., Les Echinodermes “Carpoïdes” de l'Ordovicien Inférieur de la Montagne Noire 1635 (France), Paris: Editions du CNRS, 1970, pp. 1-110.

1636 Ubaghs, G., Trois Mitrata (Echinodermata: Stylophora) nouveaux de l'Ordovicien de 1637 Tchécoslovaquie, Paläont. Z., 1979, vol. 53, pp. 98-119.

1638 Ubaghs, G., Réflexions sur la nature et la fonction de l'appendice articulé des "carpoïdes" 1639 Stylophora (Echinodermata), Ann. Paléont., 1981, vol. 67, pp. 33-48.

1640 Ubaghs, G., Deux Stylophora (Homalozoa, Echinodermata) nouveaux pour l'Ordovicien 1641 inférieur de la Montagne Noire (France méridionale), Paläont. Z., 1991, vol. 65, pp. 1571642171.

1643 Ubaghs, G., Echinodermes nouveaux (Stylophora, Eocrinoidea) de l'Ordovicien inférieur de 1644 la Montagne Noire (France), Ann. Paléont., 1994, vol. 80, pp. 107-141.

1645 Ubaghs, G., Echinodermes nouveaux du Cambrien supérieur de la Montagne Noire (France 1646 méridionale), Geobios, 1998, vol. 31, pp. 809-829.

1647 Ware, D. and Lefebvre, B., Abnormalities in the Lower Ordovician cornute Phyllocystis 1648 Thoral (Echinodermata: Stylophora) of Montagne Noire (southern France): implications 1649 for plate homology and phylogeny, J. Paleont., 2007, vol. 81, pp. 779-787.

1650 Woods, I.S. and Jefferies, R.P.S., A new stem-group chordate from the Lower Ordovician of 1651 South Wales, and the problem of locomotion in boot-shaped cornutes, Palaeontology, 1652 1992, vol. 35, pp. 1-25. 
1653 Zamora, S., Lefebvre, B., Alvaro, J.J., Clausen, S., Elicki, O., Fatka, O., Jell, P., Kouchinsky, 1654 A., Lin, J.P., Nardin, E., Parsley, R.L., Rozhnov, S.V., Sprinkle, J., Sumrall, C.D., 1655 Vizcaïno, D. and Smith, A.B., Cambrian echinoderm diversity and palaeobiogeography, in 1656 Early Palaeozoic Biogeography and Palaeogeography, Harper, D.A.T and Servais, T., 1657 Eds, Geol. Soc. London Mem., 2013a, vol. 38, pp. 157-171.

1658 Zamora, S., Zhu, X. and Lefebvre, B., A new Furongian (Cambrian) Echinoderm-Lagerstätte 1659 from the Sandu Formation (South China), Cah. Biol. Mar., 2013b, vol. 54, pp. 565-569.

1660 Zhu, X, Peng, S., Zamora, S., Lefebvre, B. and Chen, G., Furongian (upper Cambrian) Guole 1661 Konservat-Lagerstätte from South China, Acta Geologica Sinica, 2016, vol. 90, pp. 8011662808.

1663

\section{FIGURE CAPTIONS}

1665

1666

1667

Fig. 1. Location and geology of Anticosti Island: (a) location of Québec in North America; (b) location of Anticosti Island in Québec; (c) geological map of Anticosti Island; the star indicates the position of the locality yielding stylophoran remains (modified from Ausich and Cournoyer, 2019). With the exception of the Vauréal (Katian) and Ellis Bay (Hirnantian) formations, all other lithostratigraphic units are Silurian (Llandovery; see Fig. 2).

1673 Fig. 2. Silurian stratigraphic chart for Anticosti Island (modified from Copper et al., 2013); 1674 the star indicates the lithostratigraphic unit yielding mitrate remains.

Fig. 3. Location of Presto El Peral section (Bolivia): (a) location of Bolivia in South America; (b) location of study area in Bolivia; (c) location of the Presto El Peral section (indicated 
by a star), where mitrates were found (redrawn from Gaillard and Rachebœuf, 1993;

1679 Lefebvre and Rachebœuf, 2007).

1680

1681 Fig. 4. Devonian stratigraphic chart for the Central Subandean Zone of Bolivia (correlations 1682 based on Rachebœuf et al., 1993; Troth, 2006; Di Pasquo and Noetinger, 2008); the star 1683 indicates the lithostratigraphic unit, where mitrates were collected, at the top of the Santa 1684 Rosa Formation.

1685

Fig. 5. Stylophoran morphology; reconstruction of the mitrocystitidan mitrate Vizcainocarpus dentiger (late Tremadocian, France), redrawn from holotype (UCBL-FSL 712665) and previous reconstructions (Ruta, 1997d; Lefebvre, 2000b); (a) upper surface; (b) lower surface; the original extension of the arm was probably longer (anterior part missing).

1690

Fig. 6. Plate patterns of the lower thecal surface and homologies in early stylophorans; (a) Ceratocystis perneri (Wuliuan, Czech Republic), redrawn from Ubaghs (1967a, 1967b); (b) Ponticulocarpos robisoni (Wuliuan, USA), redrawn and modified from Sumrall and Sprinkle (1999); (c) Flabellicarpus rushtoni (late Tremadocian, UK) redrawn from Marti Mus (2002). Designations: $\left(\mathrm{A}_{0}\right)$ median adoral, $\left(\mathrm{A}_{1}\right)$ right adoral, $\left(\mathrm{A}_{1}^{\prime}{ }_{1}\right)$ left adoral, (D) digital, (G) glossal, $\left(\mathrm{M}_{1}-\mathrm{M}_{5}\right)$ right marginals, ( $\left.\mathrm{M}_{1}{ }_{1}-\mathrm{M}_{5}^{\prime}\right)$ left marginals, (Mc) cothurnocystid marginal, (Z) zygal plate.

1698

1699 Fig. 7. Plate patterns of the lower thecal surface and homologies in early mitrates and related forms; (a) Lobocarpus vizcainoi (Furongian, France), redrawn from Lefebvre (2000b); (b) Chinianocarpos thorali (late Tremadocian, France), redrawn from Ubaghs (1970); (c) 1702 Peltocystis cornuta (late Tremadocian, France and Morocco), redrawn from Ubaghs 
1704 marginals, (Mc) cothurnocystid marginal, (Z) zygal plate.

1705

1706 Fig. 8. Lower thecal surface of a 'Phyllocystis' jingxiensis-like stylophoran (Furongian, 1707 France); camera-lucida drawing of specimen UCBL-FSL 712773; (a) interpretation (plate 1708 homologies) of plate pattern; (b) main morphological features; the central position of $\mathrm{Z}$ 1709 results from the joining of both $\mathrm{M}_{3}$ and $\mathrm{G}$, posteriorly to it. This character ( $\mathrm{Z}$ in central 1710 position), which is shared by amygdalothecids and mitrates, is very likely inherited from a 1711 'cornute-grade' ancestor morphologically similar to 'P.' jingxiensis. Designations: (D) 1712 digital, (G) glossal, $\left(\mathrm{M}_{1}-\mathrm{M}_{3}\right)$ right marginals, $\left(\mathrm{M}_{1}^{\prime}-\mathrm{M}_{4}^{\prime}\right)$ left marginals, (Mc) 1713 cothurnocystid marginal, (Z) zygal plate.

1714

1715 Fig. 9. Plate patterns of the lower thecal surface and homologies in early mitrocystitidans; (a) 1716 Ovocarpus moncereti (late Floian, France), redrawn from Lefebvre and Gutiérrez-Marco 1717 (2003); (b) Aspidocarpus bohemicus (Sandbian, Czech Republic), with typical posterior 1718 spike on $\mathrm{M}_{7}$; redrawn from Ubaghs (1979); (c) Mitrocystites mitra (Darriwilian, Czech 1719 Republic), redrawn from Ubaghs (1967a); the two posterior left infracentrals in M. mitra $1720 \quad\left(\mathrm{I}_{2}\right.$ and $\left.\mathrm{I}_{3}^{\prime}\right)$ are not considered as homologous to those found in similar position in 1721 anomalocystitids (anomalocystid and barrandeocarpid plates), but as the result of 1722 convergent evolution towards left infracentral areas made of a reduced and fixed number 1723 of large elements. Designations: (D) digital, (G) glossal, $\left(\mathrm{M}_{1}-\mathrm{M}_{3}, \mathrm{M}_{6}\right)$ right marginals, $1724\left(\mathrm{M}_{7}\right)$ posterior median marginal, $\left(\mathrm{M}_{1}^{\prime}-\mathrm{M}_{4}^{\prime}, \mathrm{M}_{6}^{\prime}\right)$ left marginals, (Mc) cothurnocystid 1725 marginal, (Z) zygal plate. 
1727 Fig. 10. Lower thecal surface of the earliest known anomalocystitid (middle Floian, 1728 Morocco); camera-lucida drawing of specimen UCBL-FSL 711719; (a) interpretation 1729 (plate homologies) of plate pattern; (b) main morphological features; two posterior skeletal 1730 elements ( $D$ and $G$ ) are no longer part of the marginal frame, but articulated to it and

1731 modified as posterior spines. Designations: (D) digital, $(\mathrm{G})$ glossal, $\left(\mathrm{M}_{1}-\mathrm{M}_{3}, \mathrm{M}_{6}\right)$ right 1732 marginals, $\left(\mathrm{M}_{7}\right)$ posterior median marginal, $\left(\mathrm{M}_{1}^{\prime}-\mathrm{M}_{4}^{\prime}, \mathrm{M}_{6}^{\prime}\right)$ left marginals, (Mc) 1733 cothurnocystid marginal, $(\mathrm{Z})$ zygal plate.

1734

1735 Fig. 11. Plate patterns of the lower thecal surface and homologies in allanicytidiine 1736 anomalocystitids; (a) Enoploura popei (Katian, USA), redrawn from Parsley (1991); (b) Protocytidium elliottae (Hirnantian, Australia), redrawn from Ruta and Jell (1999a); (c) Placocystella garratti (Ludlow, Australia), redrawn from Ruta (1999a); Ordovician allanicytidiines retain two left infracentral elements, whereas all Siluro-Devonian taxa have only one. Designations: (A) anomalocystid plate, (B) barrandeocarpid plate, (D) digital, $(\mathrm{G})$ glossal, $\left(\mathrm{M}_{1}-\mathrm{M}_{3}, \mathrm{M}_{6}\right)$ right marginals, $\left(\mathrm{M}_{7}\right)$ posterior median marginal, $\left(\mathrm{M}_{1}{ }_{1}-\right.$ $\mathrm{M}_{4}{ }_{4}, \mathrm{M}_{6}^{\prime}$ ) left marginals, (Mc) cothurnocystid marginal, (Z) zygal plate.

1743

1744 Fig. 12. Plate patterns of the upper thecal surface and homologies in early stylophorans and 1745 mitrates; (a) Ceratocystis perneri (Wuliuan, Czech Republic), redrawn from Ubaghs 1746 (1967a, 1967b); (b) Lagynocystis pyramidalis (Furongian, China; late Tremadocian, 1747 Morocco; late Floian, France; Dapingian, UK; Darriwilian, Czech Republic, France and 1748 Spain; Sandbian, France and Russia), redrawn from Ubaghs (1967a); (c) Peltocystis cornuta (late Tremadocian, France and Morocco), redrawn and modified from Ubaghs (1970) and Lefebvre and Botting (2007). Designations: (D) digital, (G) glossal, $\left(\mathrm{M}_{1}-\mathrm{M}_{4}\right)$ right marginals, $\left(\mathrm{M}_{1}{ }_{1}-\mathrm{M}_{4}{ }_{4}\right)$ left marginals, $(\mathrm{Mc})$ cothurnocystid marginal, $(\mathrm{Z})$ zygal plate. 
1753 Fig. 13. Morphology of upper thecal surface of two early anomalocystitids, both with their 1754 supracentral area entirely consisting of numerous, unorganized, imbricate elements; (a) 1755 earliest known anomalocystitid (middle Floian, Morocco), camera-lucida drawing of 1756 specimen UCBL-FSL 711717; (b) Diamphidiocystis sp. (Darriwilian, France), camera1757 lucida drawing of specimen IGR 15217. Designations: $\left(\mathrm{A}_{0}\right.$ ?) possible median adoral, $\left(\mathrm{A}_{1}\right)$ 1758 right adoral, $\left(\mathrm{A}^{\prime}{ }_{1}\right)$ left adoral.

1759

1760 Fig. 14. Plate patterns of the upper thecal surface and homologies in allanicytidiine 1761 anomalocystitids; (a) Enoploura popei (Katian, USA), redrawn from Parsley (1991); (b) 1762 Protocytidium elliottae (Hirnantian, Australia), redrawn from Ruta and Jell (1999a); (c) 1763 Occultocystis koeneni (Lower Devonian, Argentina), redrawn from Haude (1995). 1764 Designations: $\left(\mathrm{A}_{0}\right.$ ?) possible median adoral, $\left(\mathrm{A}_{1}\right)$ right adoral, $\left(\mathrm{A}_{1}^{\prime}\right)$ left adoral, $\left(\mathrm{B}_{2}, \mathrm{~B}_{2}^{\prime}\right)$ 1765 row $B$ supracentrals, $\left(\mathrm{C}_{1}, \mathrm{C}_{1}^{\prime}, \mathrm{C}_{2}, \mathrm{C}_{2}^{\prime}\right)$ row $\mathrm{C}$ supracentrals, $\left(\mathrm{E}_{0}, \mathrm{E}_{1}, \mathrm{E}_{1}^{\prime}, \mathrm{E}_{2}, \mathrm{E}_{2}^{\prime}\right)$ row $\mathrm{E}$ 1766 supracentrals.

1767

1768 Fig. 15. Plate patterns of the upper thecal surface and homologies in Late Ordovician 1769 anomalocystitids; (a) Willmanocystis denticulatus (Katian, USA), redrawn and modified 1770 from Kolata and Jollie (1982); (b) Barrandeocarpus jaekeli (Sandbian, Czech Republic), 1771 redrawn from Ubaghs (1979); (c) Ateleocystites guttenbergensis (Katian, USA), redrawn 1772 from Kolata and Jollie (1982). Designations: $\left(\mathrm{A}_{0}\right.$ ?) possible median adoral, $\left(\mathrm{A}_{1}\right)$ right 1773 adoral, $\left(\mathrm{A}^{\prime}{ }_{1}\right)$ left adoral, $\left(\mathrm{B}_{1}, \mathrm{~B}_{1}^{\prime}, \mathrm{B}_{2}, \mathrm{~B}_{2}^{\prime}\right)$ row $\mathrm{B}$ supracentrals, $\left(\mathrm{C}_{1}, \mathrm{C}^{\prime}{ }_{1}, \mathrm{C}_{2}, \mathrm{C}_{2}^{\prime}\right)$ row $\mathrm{C}$ supracentrals, $\left(E_{0}, E_{1}, E_{1}^{\prime}, E_{2}, E_{2}^{\prime}\right)$ row E supracentrals, $(P)$ placocystid plate. 
1776 Fig. 16. Plate patterns of the upper thecal surface and homologies in Siluro-Devonian

1777

1778

1779

1780

1781

1782

1783

1784

1785

1786

1787

1788

1789

1790

1791

1792

1793

1794

1795

1796

1797

1798

1799

1800

anomalocystitine mitrates; (a) Placocystites forbesianus (Wenlock, UK), redrawn from Jefferies and Lewis (1978); (b) Bokkeveldia oosthuizeni (Emsian, South Africa), redrawn from Ruta and Theron (1997), original size of single known individual not mentioned in Ruta and Theron (1997): dimensions based on specimen of Bokkeveldia sp. (Lower Devonian, Morocco) figured by Régnault and Chauvel (1987, fig. 1); (c) Anomalocystites cornutus (Lower Devonian, USA), redrawn and modified from Parsley (1991) and Ruta (1999a). Designations: $\left(\mathrm{A}_{0}\right.$ ?) possible median adoral, $\left(\mathrm{A}_{1}\right)$ right adoral, $\left(\mathrm{A}_{1}^{\prime}\right)$ left adoral, $\left(\mathrm{B}_{1}, \mathrm{~B}_{1}^{\prime}, \mathrm{B}_{2}, \mathrm{~B}_{2}^{\prime}\right)$ row B supracentrals, $\left(\mathrm{III}_{0}, \mathrm{III}_{1}, \mathrm{III}_{1}, \mathrm{III}_{2}, \mathrm{III}_{2}^{\prime}\right)$ row III supracentrals, $\left(\mathrm{IV}_{1}\right.$, $\left.I^{\prime}{ }_{1}, I V_{2}, I V_{2}^{\prime}, I V_{3}, I V_{3}^{\prime}\right)$ row IV supracentrals, $\left(V_{1}, V^{\prime}{ }_{1}, V_{2}, V_{2}^{\prime}\right)$ row $V$ supracentrals, $\left(V_{0}\right.$, $\left.\mathrm{VI}_{1}, \mathrm{VI}_{1}, \mathrm{VI}_{2}, \mathrm{VI}_{2}\right)$ row $\mathrm{VI}$ supracentrals, $(\mathrm{P})$ placocystid plate.

Fig. 17. Perikefalea racheboeufi sp. nov., holotype MHNC 13354; (a-b) theca in lower aspect, with articulated spines, proximal aulacophore and plougshare-shaped stylocone, with expanded distal transverse blade ; (a) photographic view; (b) interpretative cameralucida drawing; (c-d) theca in upper aspect, with proximal aulacophore and two first pairs of ambulacral cover plates; (c) interpretative camera-lucida drawing; (d) photographic view. Designations: $(\mathrm{A})$ anomalocystid plate, $\left(\mathrm{A}_{0}\right.$ ?) possible median adoral, $\left(\mathrm{A}_{1}\right)$ right adoral, ( $\left.\mathrm{A}_{1}{ }_{1}\right)$ left adoral, $\left(\mathrm{C}_{1}, \mathrm{C}_{1}^{\prime}\right)$ supracentrals, (cov. pl.) cover plates, (dig.) digital, (gloss.) glossal, $\left(\mathrm{M}_{1}-\mathrm{M}_{4}, \mathrm{M}_{6}\right)$ right marginals, $\left(\mathrm{M}_{7}\right)$ posterior median marginal, $\left(\mathrm{M}_{1}^{\prime}-\mathrm{M}_{4}^{\prime}\right.$, $\mathrm{M}_{6}{ }_{6}$ ) left marginals, (Mc) cothurnocystid marginal, (prox.) proximal aulacophore; styl.: stylocone, (Z) zygal plate.

Fig. 18. Perikefalea racheboeufi sp. nov., specimen MHNC 13355; (a-b) theca in lower aspect, with aulacophore insertion cavity exposed; (a) photographic view; (b) interpretative 
camera-lucida drawing; (c-d) theca in upper aspect; (c) interpretative camera-lucida drawing; (d) photographic view. Designations: (A) anomalocystid plate, $\left(\mathrm{A}_{0}\right.$ ?) possible median adoral, $\left(\mathrm{A}_{1}\right)$ right adoral, $\left(\mathrm{A}_{1}^{\prime}\right)$ left adoral, (aul. insert. cav.) aulacophore insertion cavity, $\left(\mathrm{C}_{1}, \mathrm{C}_{1}\right)$ supracentrals, $\left(\mathrm{M}_{1}-\mathrm{M}_{4}, \mathrm{M}_{6}\right)$ right marginals, $\left(\mathrm{M}_{7}\right)$ posterior median marginal, $\left(\mathrm{M}_{1}^{\prime}-\mathrm{M}_{4}^{\prime}, \mathrm{M}_{6}\right.$ ) left marginals, (Mc) cothurnocystid marginal, (Z) zygal plate.

1806

1807

Fig. 19. Perikefalea racheboeufi sp. nov.; (a) MHNC 13356, posterior half of the theca, in lower aspect, showing strong posterior spike on median posterior marginal $\left(\mathrm{M}_{7}\right)$ with distal supracentrals $\left(\mathrm{C}_{1}^{\prime}\right.$ and $\left.\mathrm{C}_{1}\right)$ protruding on both sides of it, and two spines (partially preserved glossal, on the left, and complete digital, on the right) articulated to posterolateral view, showing the theca and almost complete aulacophore (over twenty brachials and associated cover plates, ploughshare-like stylocone with two strong transverse blades on its lower surface, proximal aulacophore rings); the preservation of the appendage in extended (feeding) position suggests sudden burial by obrution (storm) deposits.

Fig. 20. Perikefalea racheboeufi sp. nov., reconstruction of the theca; (a) anterior aspect, with aulacophore insertion; (b) lower surface; (c) upper surface.

Fig. 21. Perikefalea racheboeufi sp. nov. thecal plate patterns and homologies; (a) upper thecal surface; (b) lower thecal surface. Designations: (A) anomalocystid plate, $\left(\mathrm{A}_{0}\right.$ ?) possible median adoral, $\left(\mathrm{A}_{1}\right)$ right adoral, $\left(\mathrm{A}_{1}^{\prime}\right)$ left adoral, $\left(\mathrm{C}_{1}, \mathrm{C}_{1}^{\prime}\right)$ supracentrals, digital, $(\mathrm{G})$ glossal, $\left(\mathrm{M}_{1}-\mathrm{M}_{3}, \mathrm{M}_{6}\right)$ right marginals, $\left(\mathrm{M}_{7}\right)$ posterior median marginal, $\left(\mathrm{M}_{1}{ }_{1}-\right.$ 
1826 Fig. 22. Perikefalea? cybeleae sp. nov., holotype GSC 126914, almost complete lower thecal 1827 surface (spines missing), with partially preserved proximal aulacophore and small, distal 1828 portion of recurved feeding arm; (a) interpretative camera-lucida drawing; (b) 1829 photographic view. Designations: (A?) probable large fragment of anomalocystid plate, $1830 \quad\left(\mathrm{M}_{7}\right)$ posterior median marginal; (prox. aulacophore) proximal aulacophore.

1831

1832 Fig. 23. Perikefalea? cybeleae sp. nov., holotype GSC 126914; (a) tentative reconstruction of 1833 lower thecal surface, with dashed areas corresponding to missing or unobserved parts; (b) 1834 photographic view of the slab containing the holotype of P.? cybeleae closely associated to 1835 a portion of crinoid stem; (c) interpretative camera-lucida drawing of small portion of 1836 distal arm, in lateral view. Designations: (A) anomalocystid plate, (cov. pl.) cover plate, $1837\left(\mathrm{M}_{1}-\mathrm{M}_{3}, \mathrm{M}_{6}\right)$ right marginals, $\left(\mathrm{M}_{7}\right)$ posterior median marginal, $\left(\mathrm{M}_{1}^{\prime}-\mathrm{M}_{4}^{\prime}, \mathrm{M}_{6}^{\prime}\right)$ left 1838 marginals, (Mc) cothurnocystid marginal, (Z) zygal plate. 


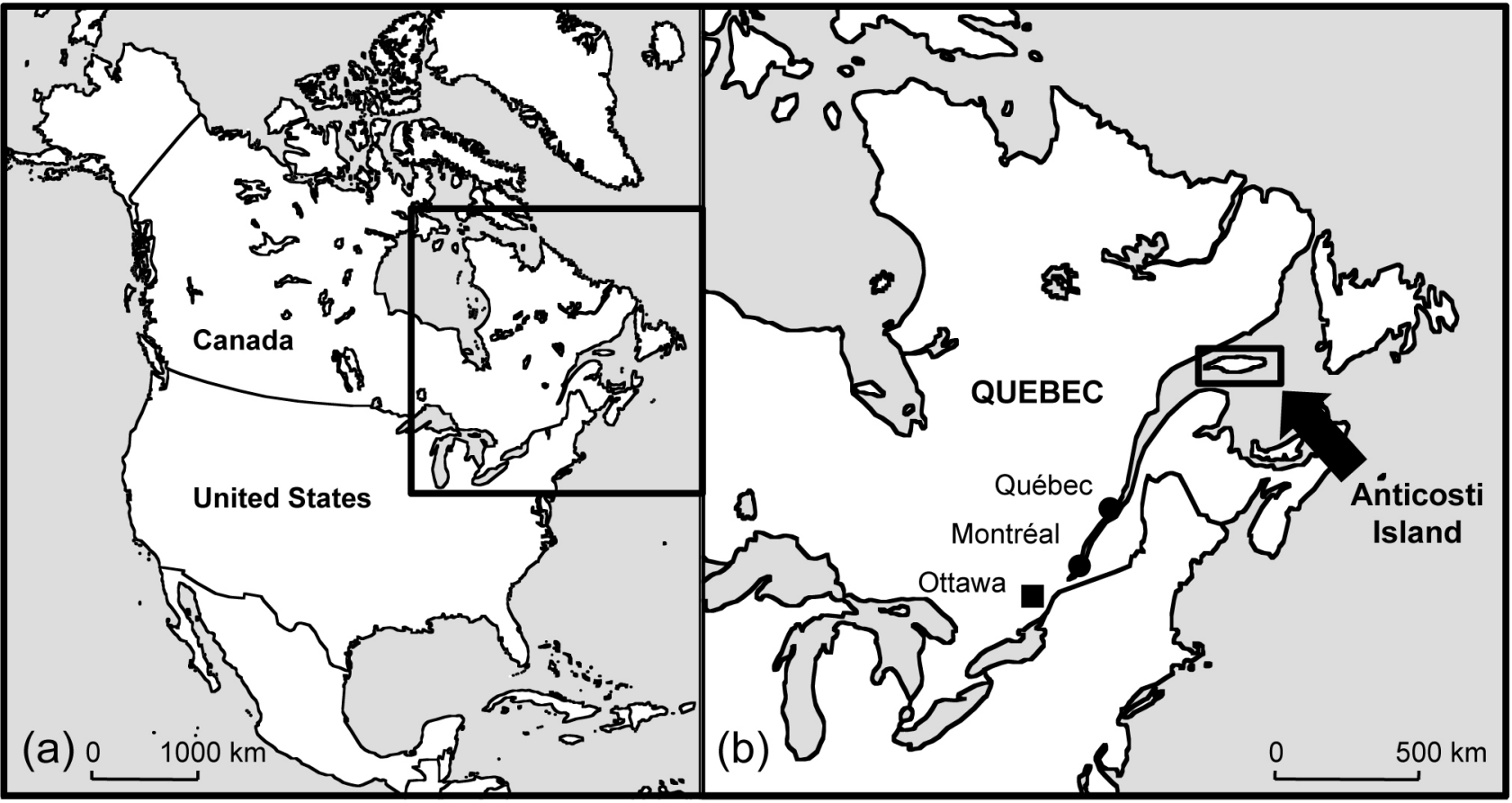

\section{English}

Head

Laframboise Menier

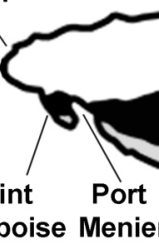

\section{ANTICOSTI ISLAND}

(c)

Southwest
Point

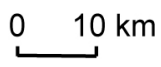

Carleton Point
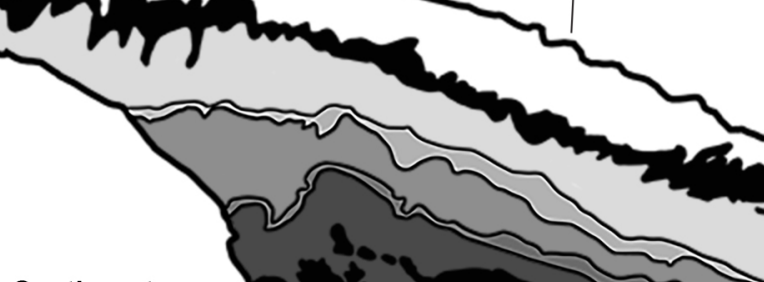

Mouth of

Salmon

River
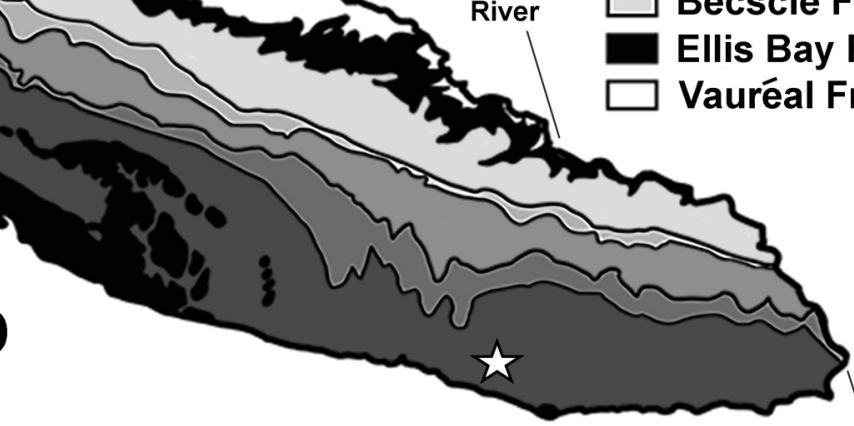

Sandtop 


\begin{tabular}{|c|c|c|c|c|}
\hline System & Series & Stage & Formation & Member \\
\hline \multirow{14}{*}{$\frac{\frac{5}{2}}{\frac{2}{2}}$} & \multirow{14}{*}{$\begin{array}{l}\frac{\lambda}{0} \\
\frac{0}{2} \\
\frac{0}{0} \\
\frac{0}{0} \\
\frac{0}{J}\end{array}$} & \multirow{4}{*}{ Telychian } & \multicolumn{2}{|c|}{ Chicotte } \\
\hline & & & \multirow{4}{*}{ Jupiter } & Pavillon \\
\hline & & & & Ferrum \\
\hline & & & & Cybèle \\
\hline & & \multirow{7}{*}{ Aeronian } & & Richardson \\
\hline & & & \multirow{2}{*}{ Menier } & East Point \\
\hline & & & & Goéland \\
\hline & & & \multirow{4}{*}{ Gun River } & Macgilvray \\
\hline & & & & Sandtop \\
\hline & & & & Innommée \\
\hline & & & & Lachute \\
\hline & & \multirow{3}{*}{ Rhuddanian } & \multicolumn{2}{|c|}{ Merrimack } \\
\hline & & & \multirow{2}{*}{ Becscie } & Chabot \\
\hline & & & & Fox Point \\
\hline
\end{tabular}




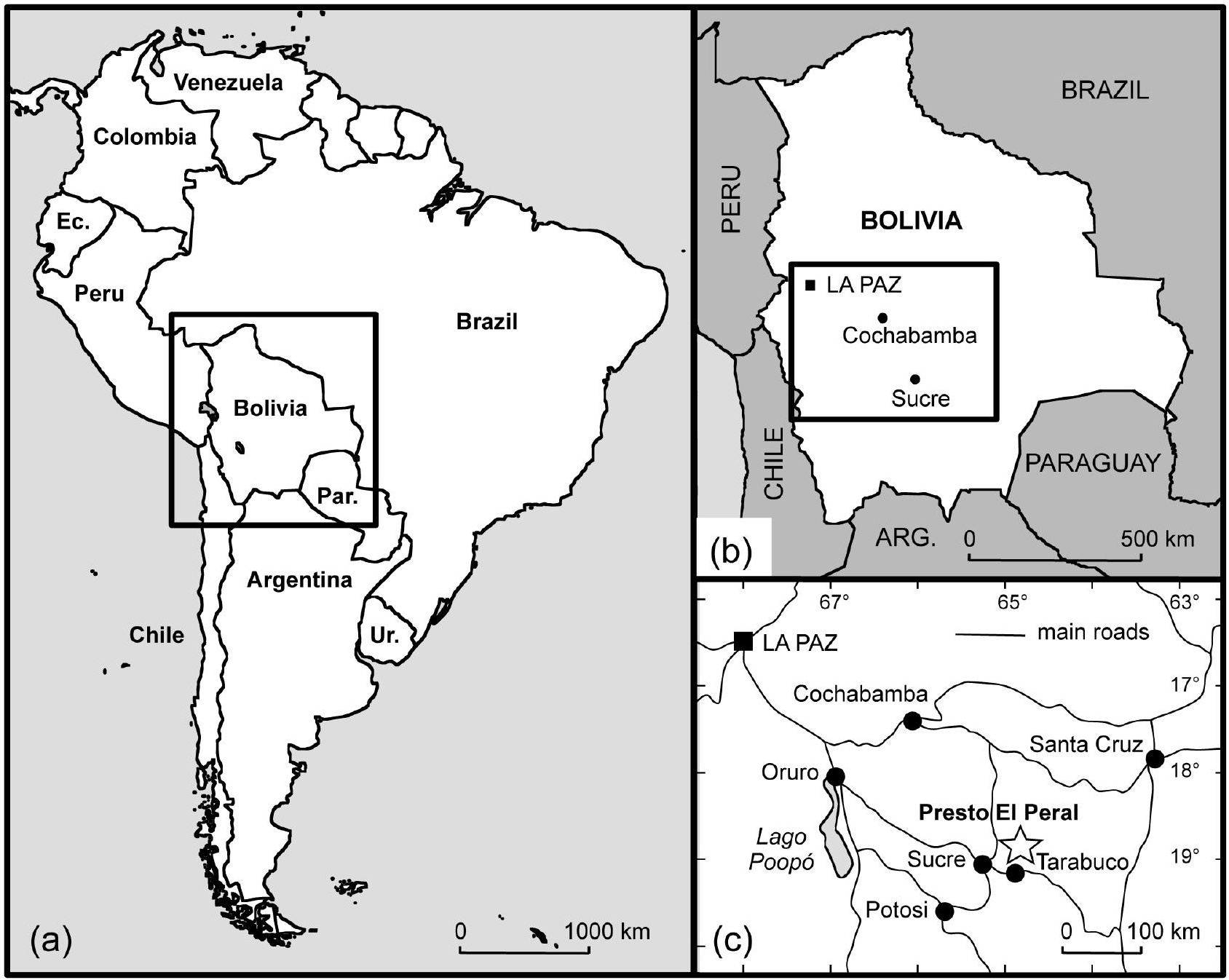




\begin{tabular}{|c|c|c|c|}
\hline System & Series & Stage & Formation \\
\hline \multirow{7}{*}{ Devonian } & \multirow{2}{*}{ Upper } & Famennian & \multirow[t]{2}{*}{ Saipuru } \\
\hline & & Frasnian & \\
\hline & \multirow{2}{*}{ Middle } & Givetian & Iquiri \\
\hline & & Eifelian & Los Monos \\
\hline & \multirow{3}{*}{ Lower } & Emsian & Huamampampa \\
\hline & & Pragian & Icla \\
\hline & & Lochkovian & Santa Rosa \\
\hline
\end{tabular}




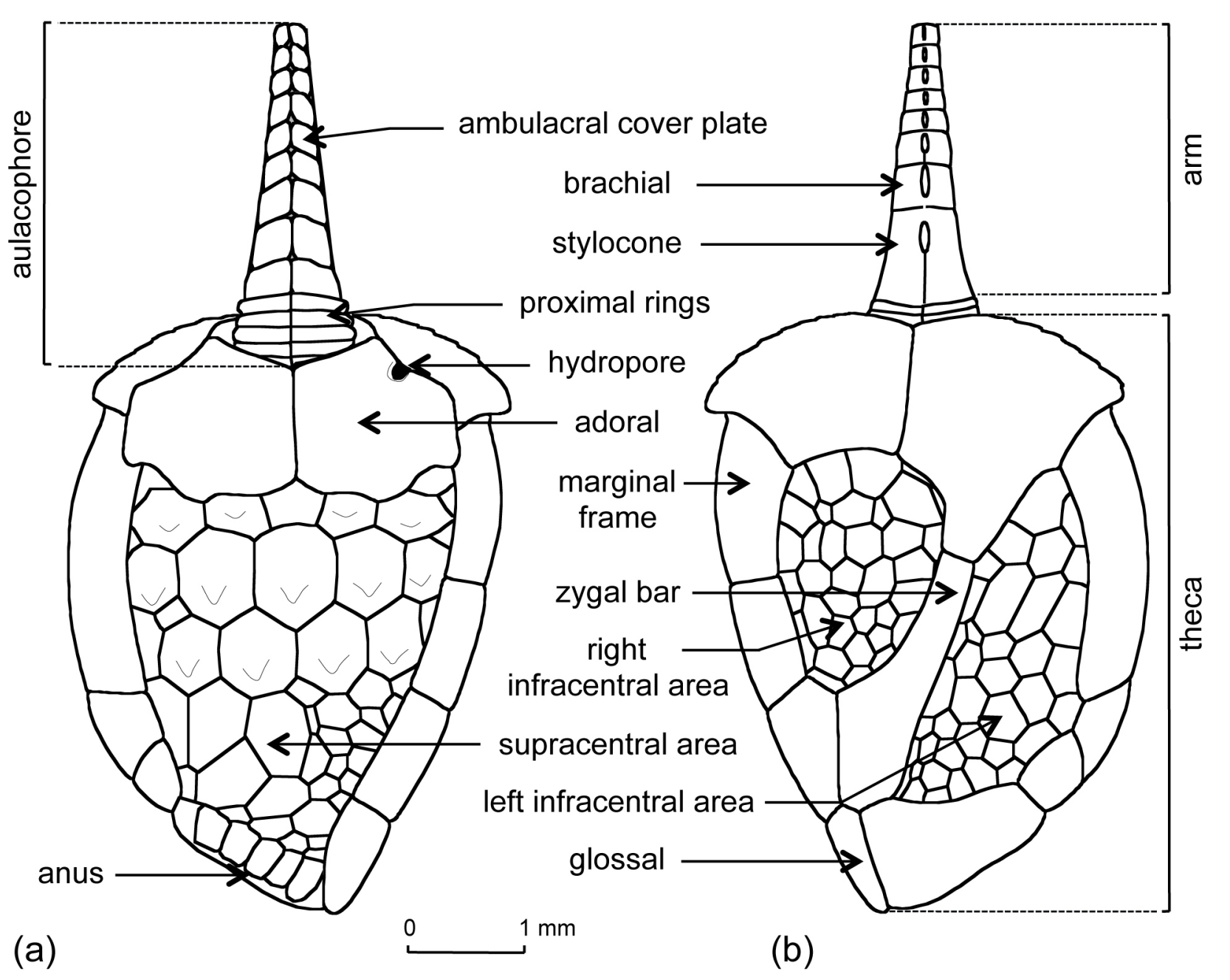



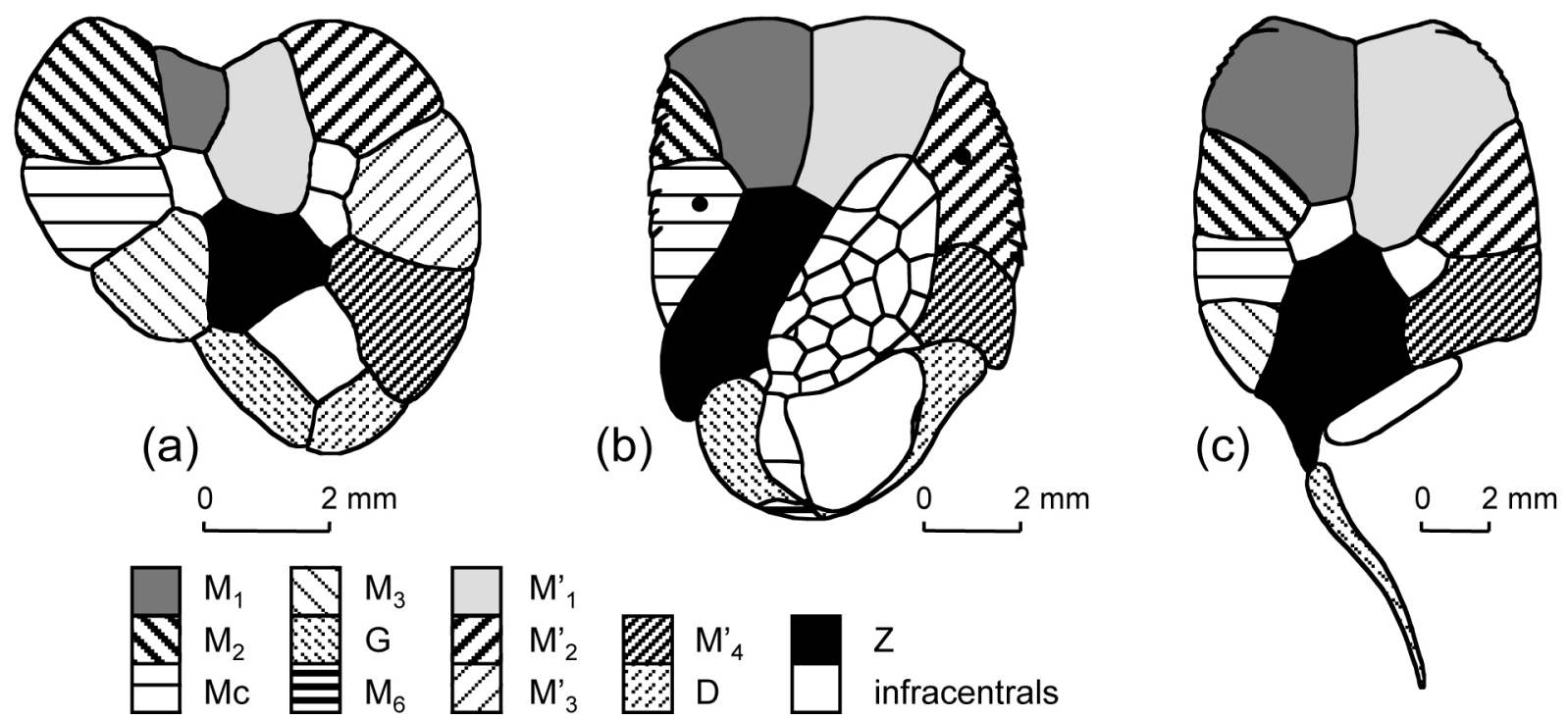

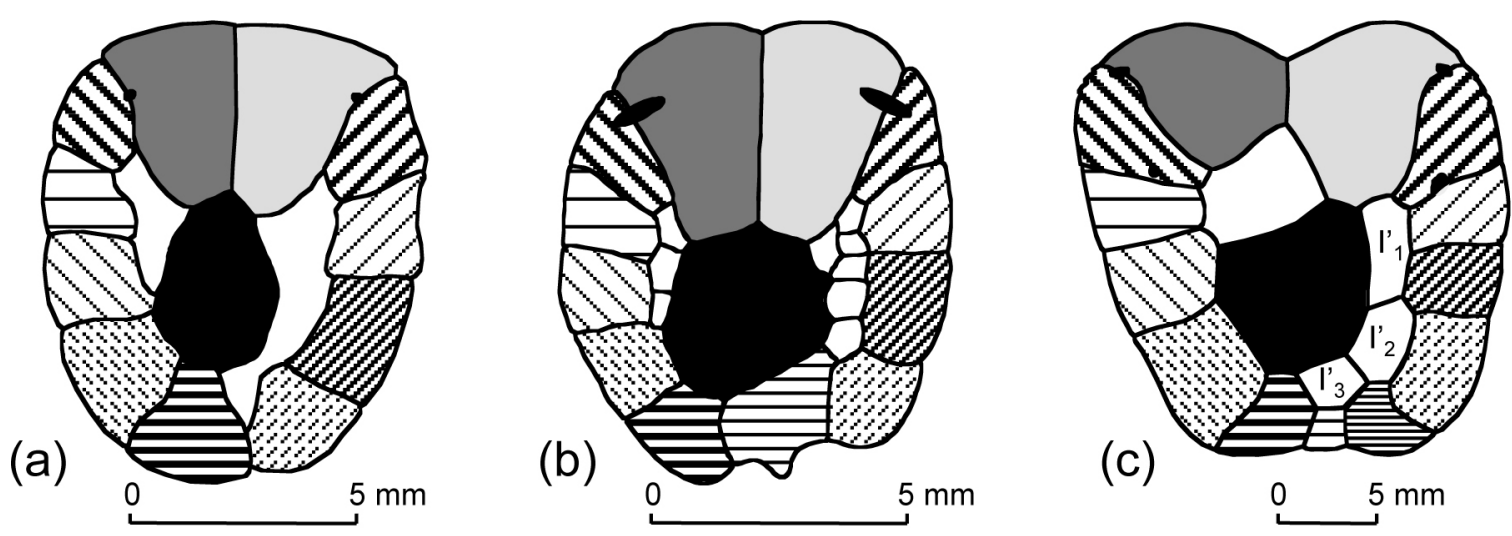

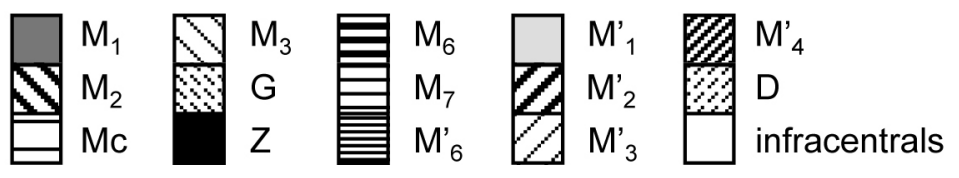




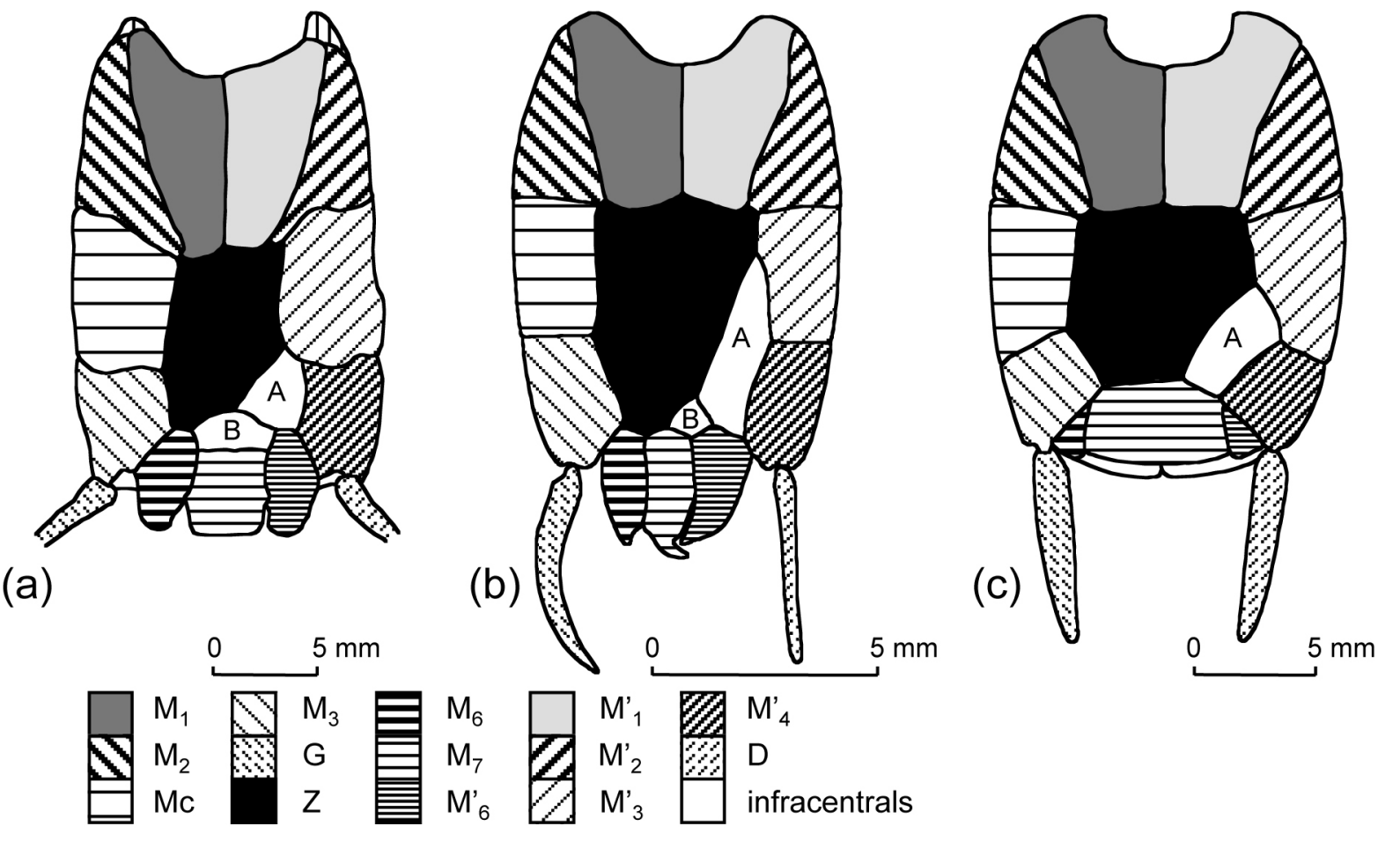




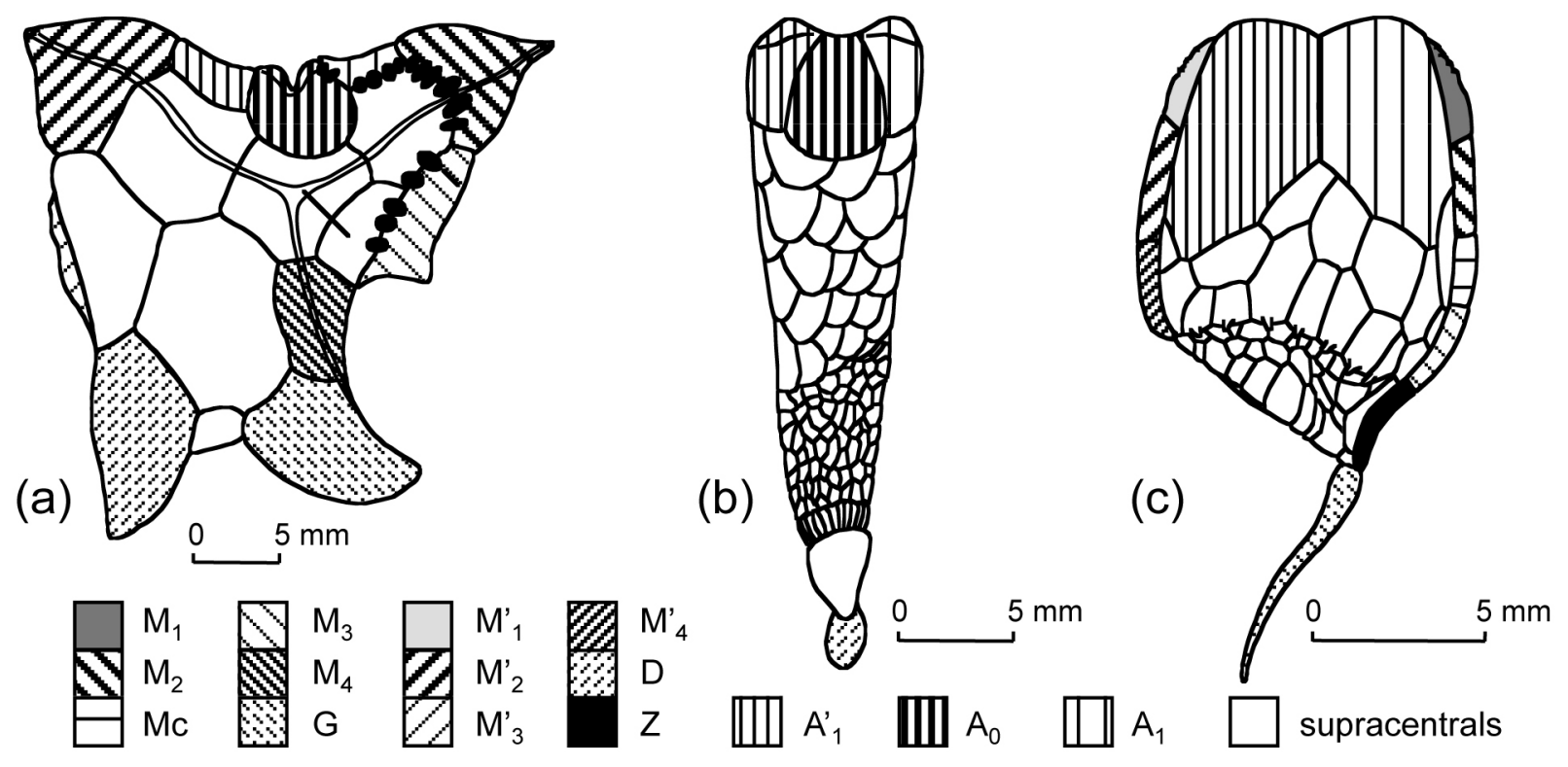




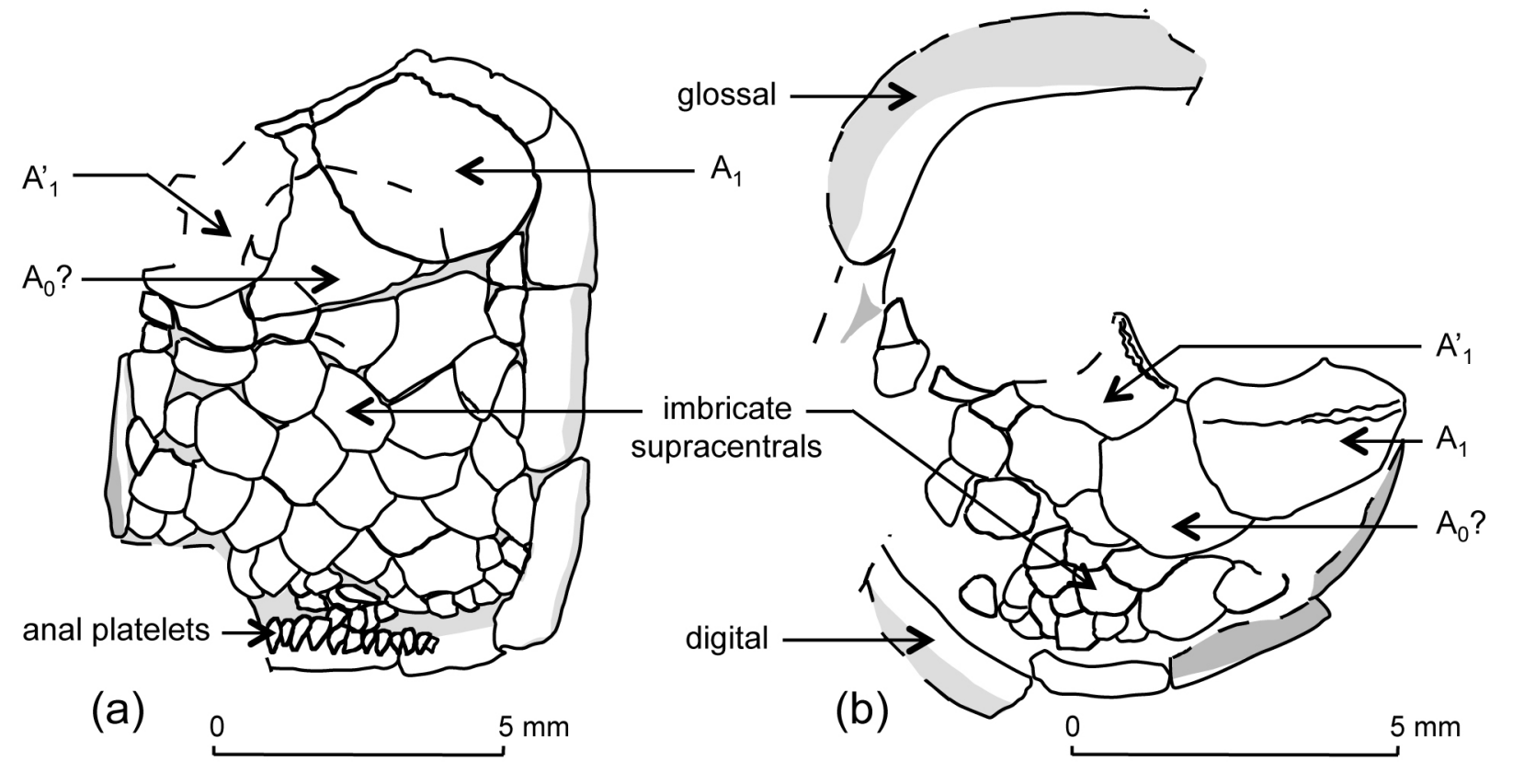



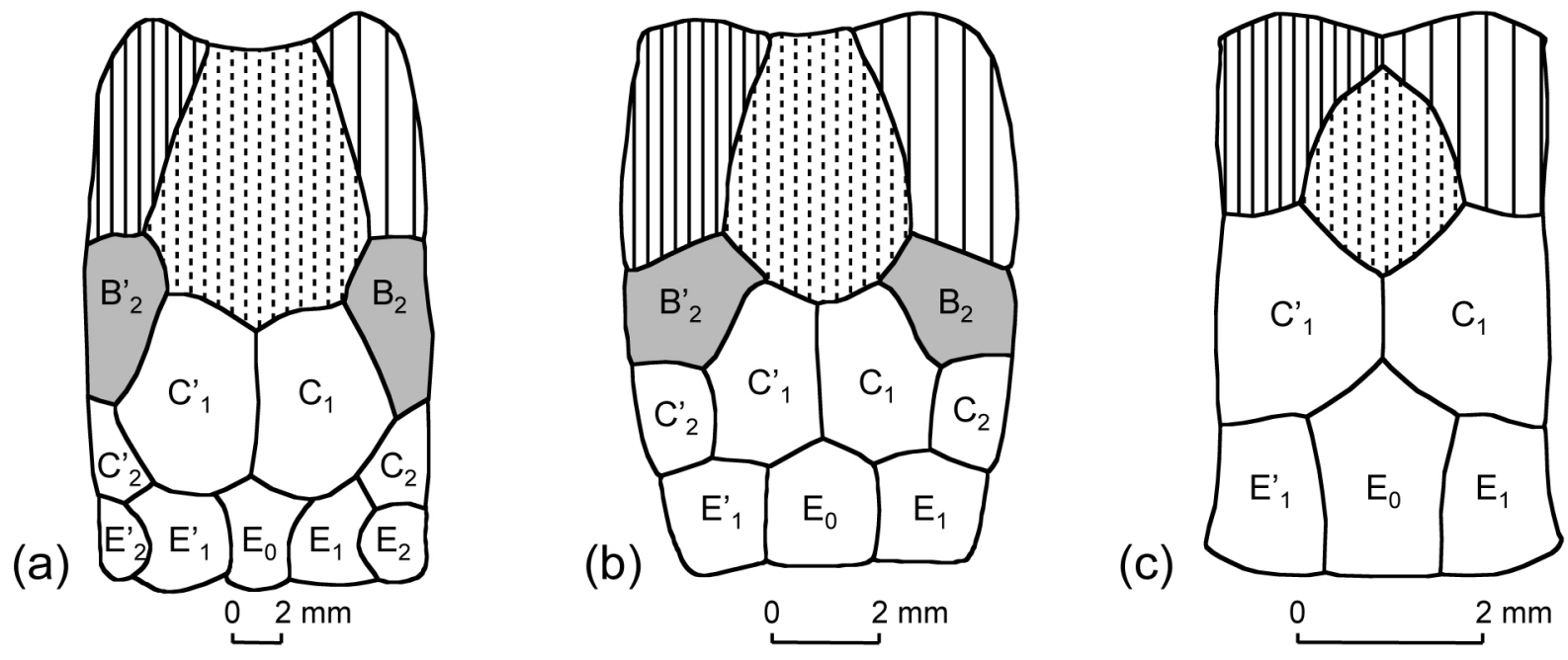

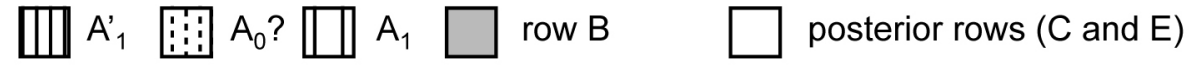




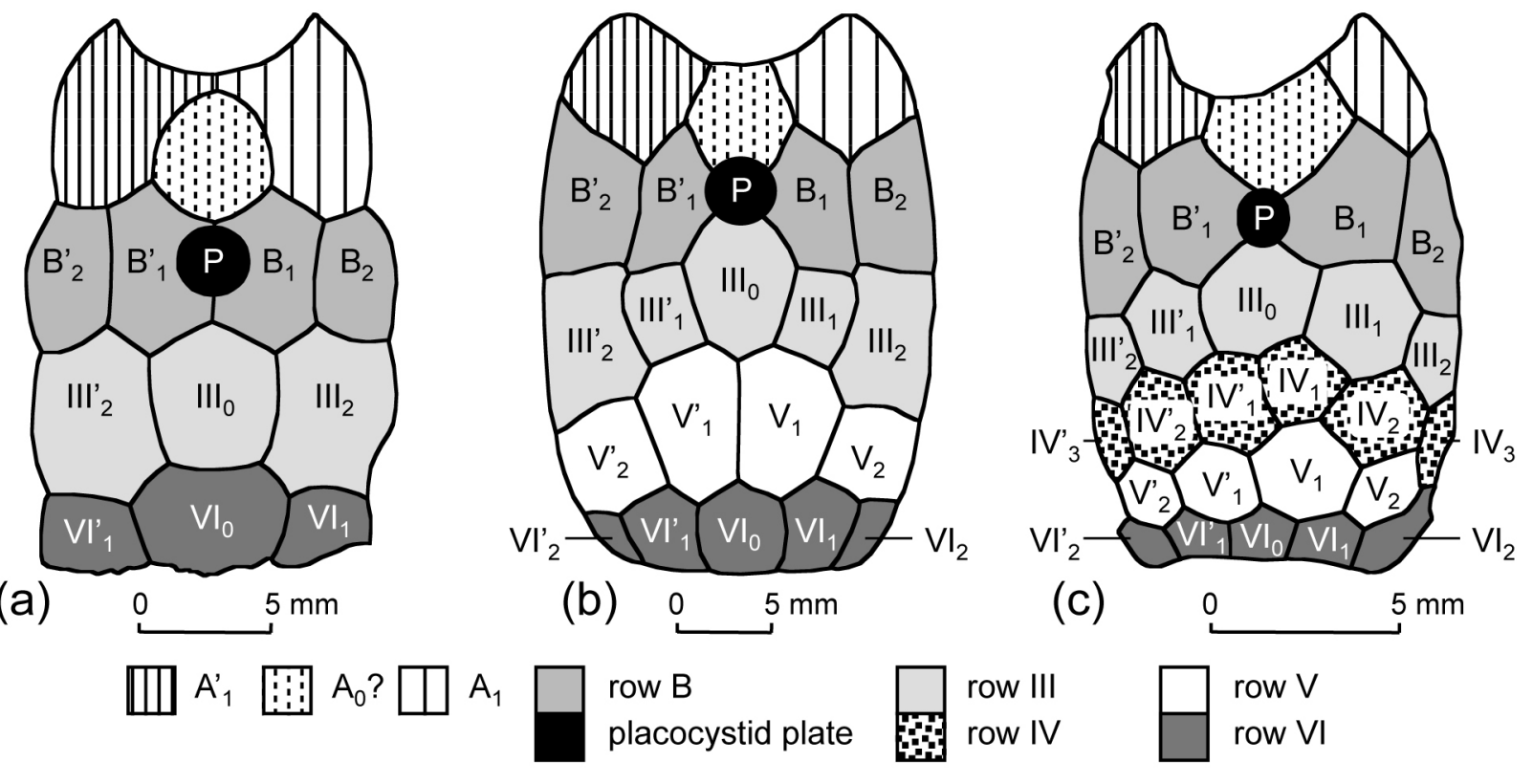




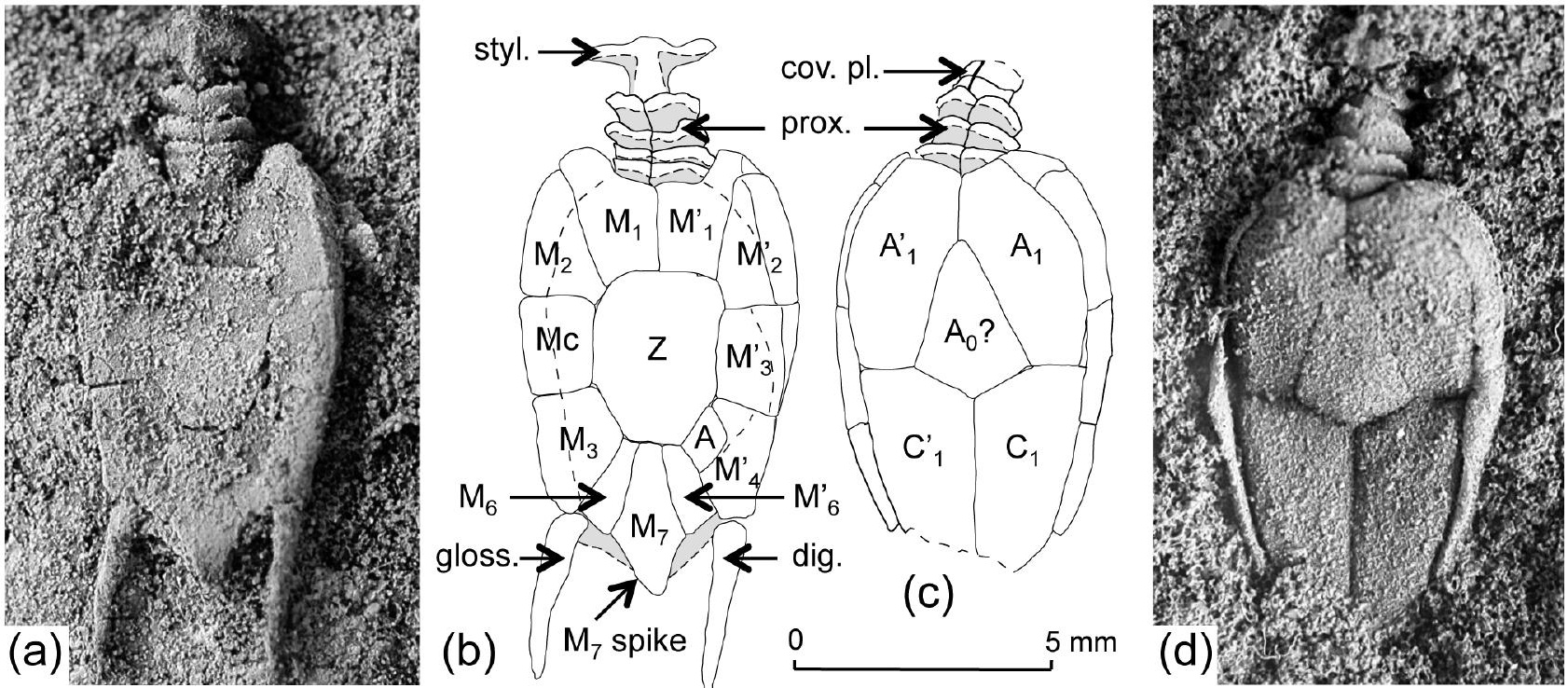




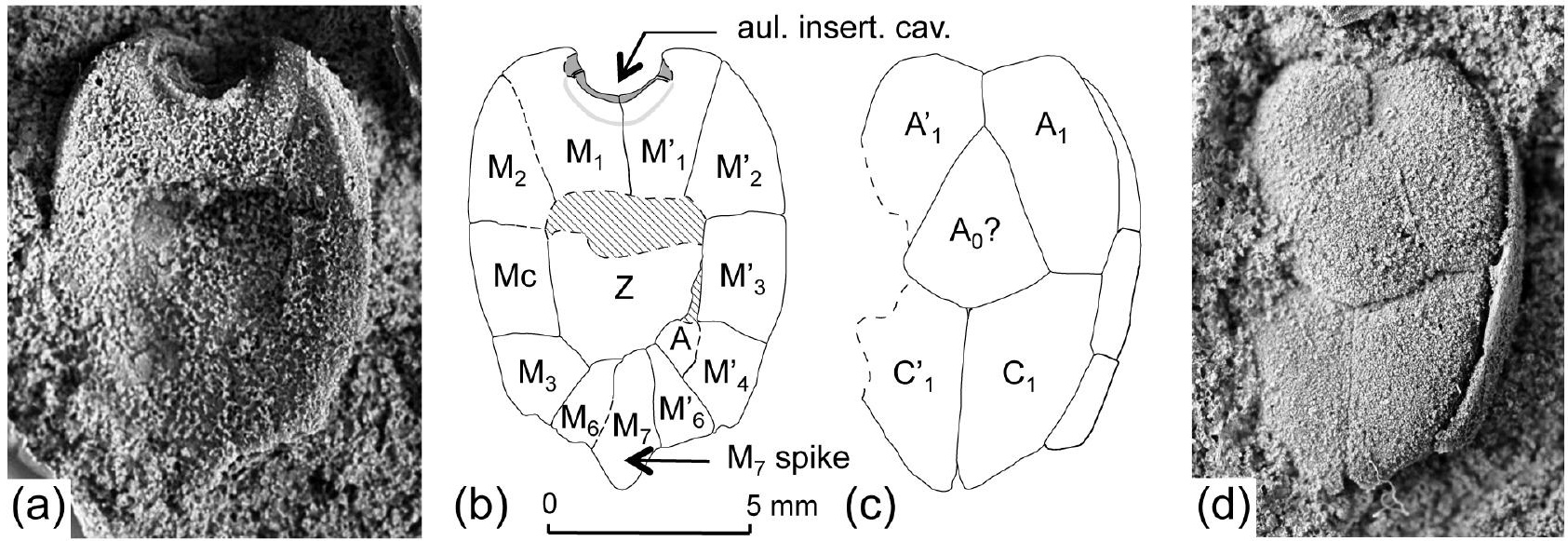




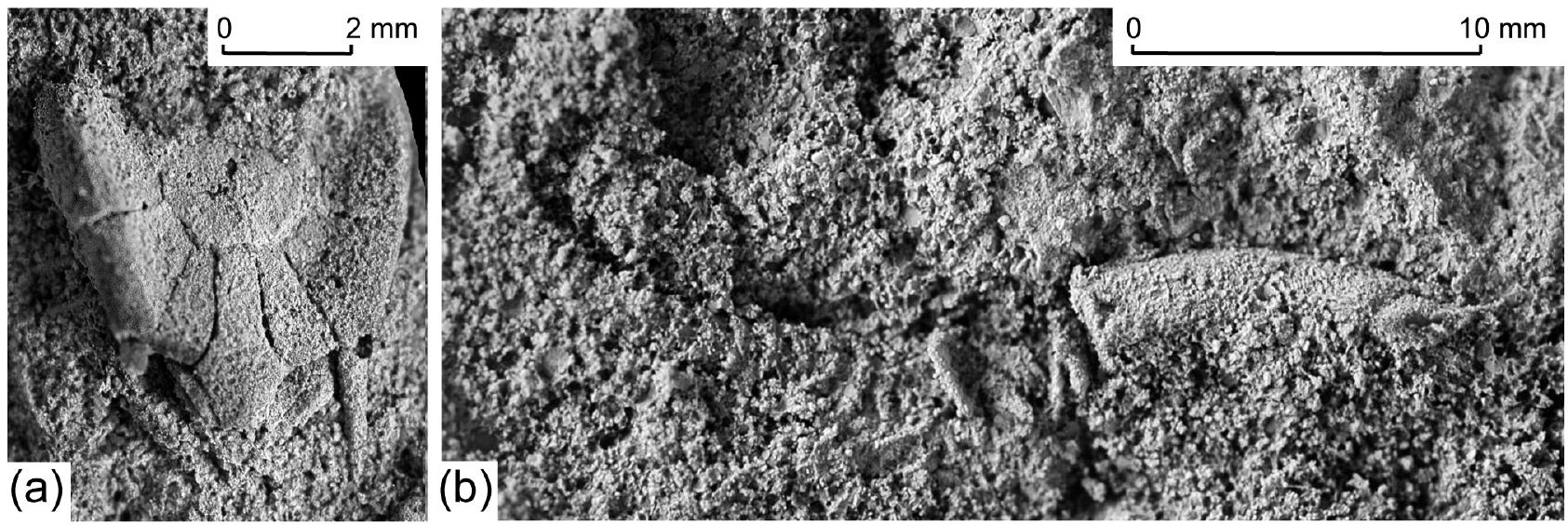


(a)
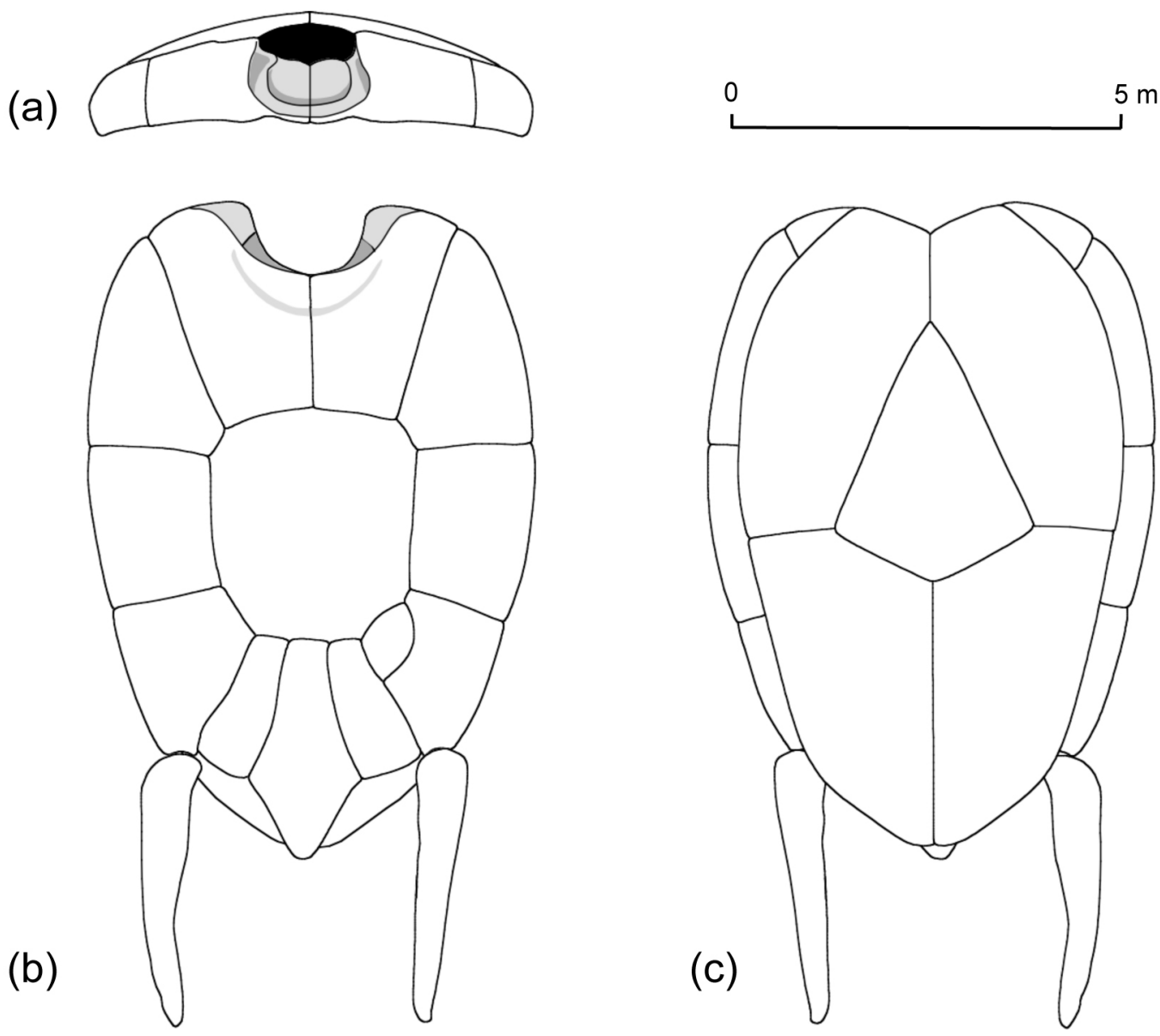


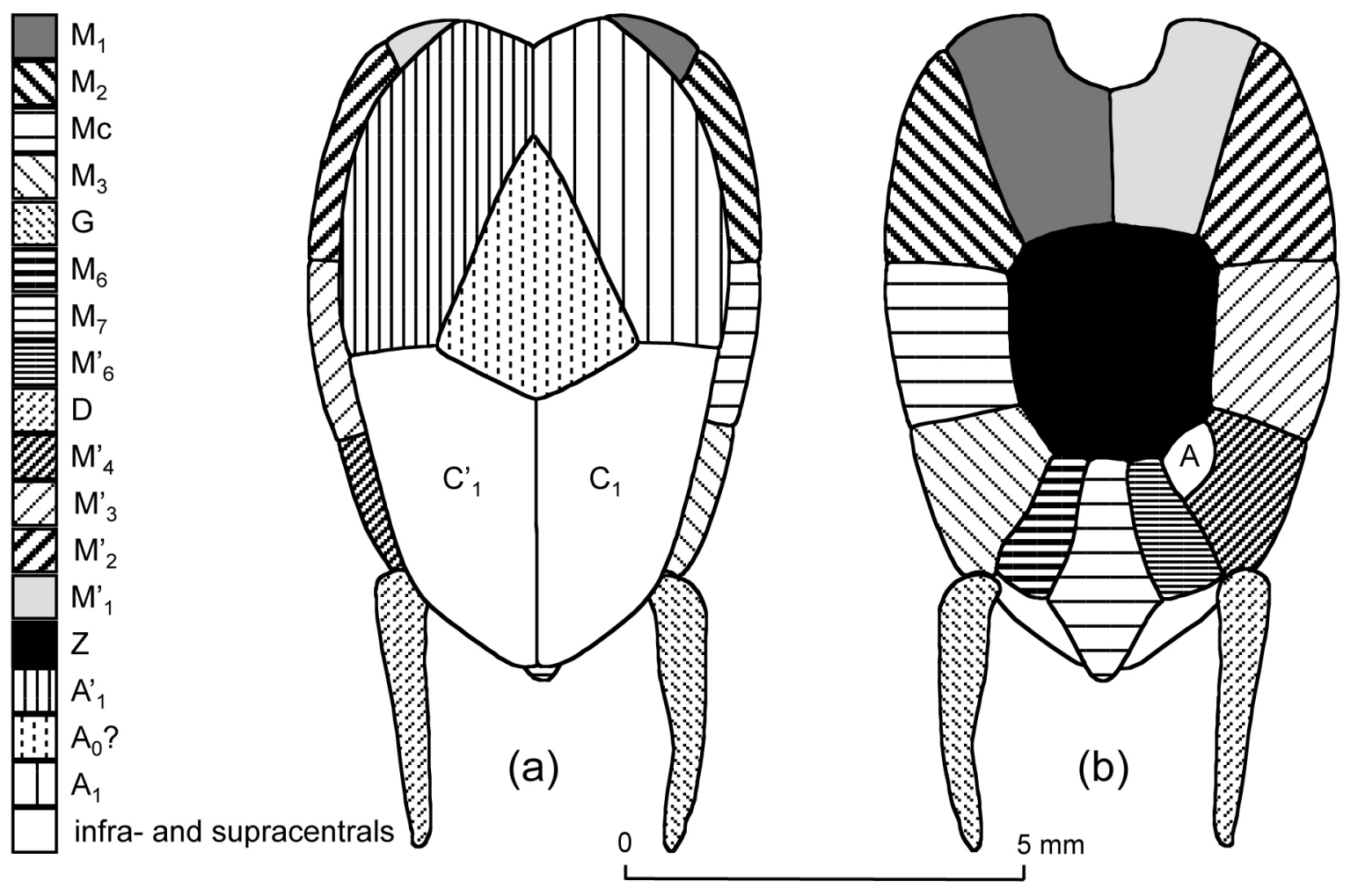



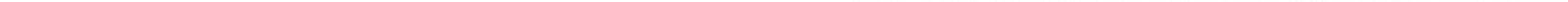


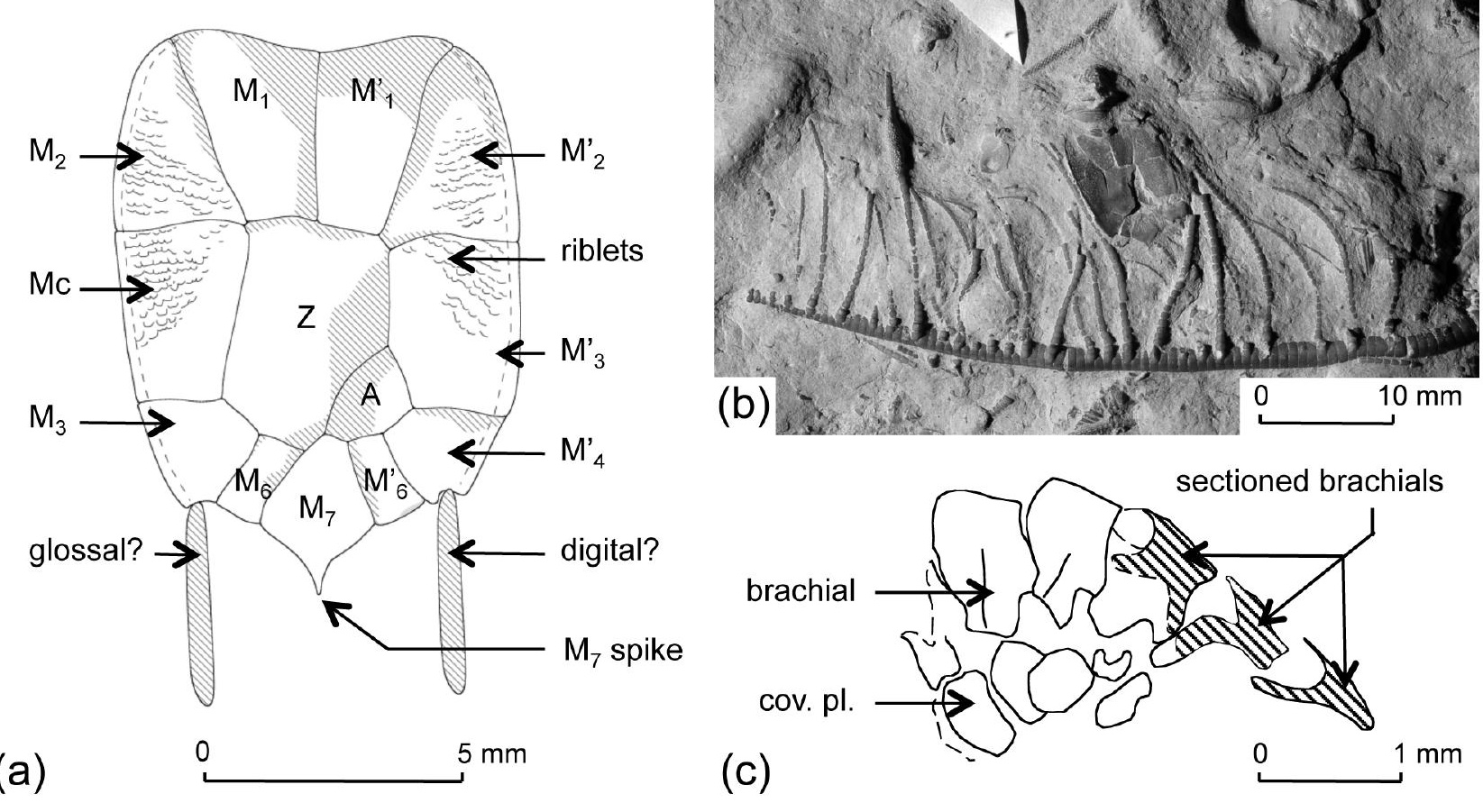

